\title{
Big Sagebrush Shrub-steppe Postfire Succession in Southwest Montana
}

\author{
Prepared for: \\ United States Department of the Interior \\ Bureau of Land Management \\ Dillon Field Office \\ By: \\ Peter Lesica, Stephen V. Cooper and Greg Kudray \\ Montana Natural Heritage Program \\ Natural Resource Information System \\ Montana State Library
}

April 2005

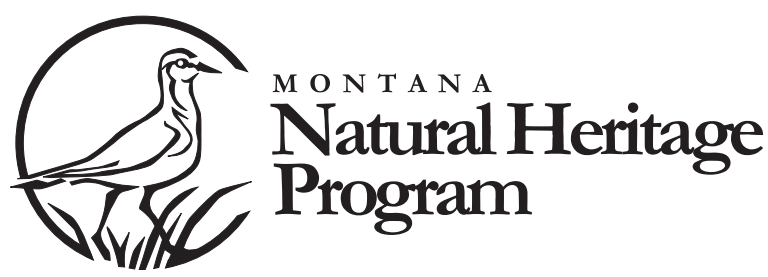




\title{
Big Sagebrush Shrub-steppe Postfire Succession in Southwest Montana
}

\author{
Prepared for:
United States Department of the Interior
Bureau of Land Management
Dillon Field Office
1005 Selway Drive
Dillon, Montana 59725

Agreement Number:

ESA010009

By:

Peter Lesica

Conservation Biology Research

and

Stephen V. Cooper and Greg Kudray

Montana Natural Heritage Program
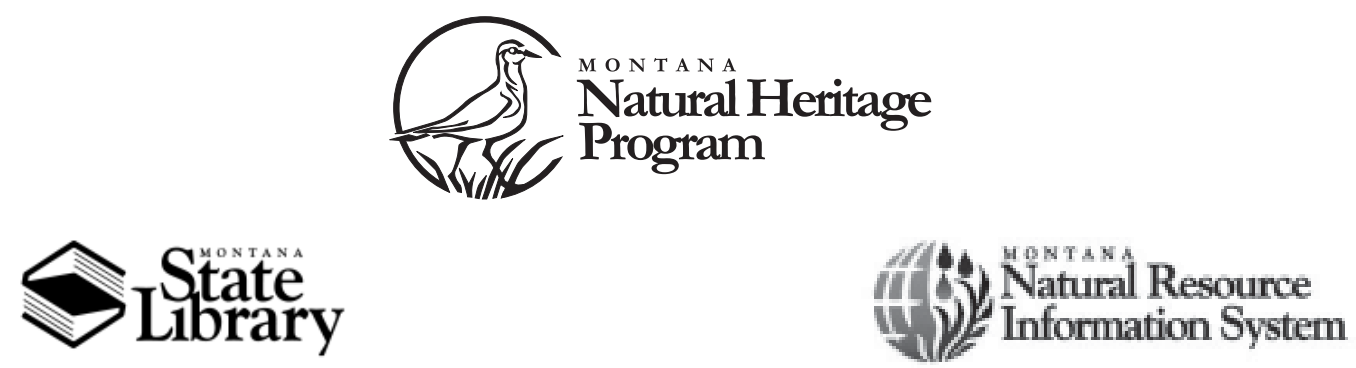

(C) 2005 Montana Natural Heritage Program

P.O. Box 201800 • 1515 East Sixth Avenue • Helena, MT 59620-1800 • 406-444-5354 
This document should be cited as follows:

Lesica, P., S. V. Cooper and G. Kudray. 2005. Big sagebrush shrub-steppe postfire succession in southwest Montana. Unpublished report to Bureau of Land Management, Dillon Field Office. Montana Natural Heritage Program, Helena, MT. 29 pp. plus appendices. 


\section{EXECUTIVE SUMMARY}

Sagebrush steppe is the dominant vegetation type in southwest Montana, and fire played a large role in structuring these ecosystems. However, we have little knowledge of how vegetation changes with time as succession proceeds from immediate postfire to mature stands. Species such as sage grouse, antelope, pygmy rabbits and Brewer's sparrow depend on sagebrush. Management activities change the composition and structure of vegetation in these communities, so comprehensive management of sagebrush at the landscape scale cannot be accomplished without understanding how these attributes change with time since disturbance. The purpose of this study was to document how sagebrush communities change with age in southern Beaverhead and adjacent Madison counties.

We sampled at 38 sites dominated by Artemisia tridentata ssp. wyomingensis, ssp. vaseyana or ssp. tridentata. Time since fire varied from 3 to 34 years among sites. At each site we subjectively located one sample plot representing the burned area and a control macroplot in similar, adjacent, unburned vegetation. Canopy cover of shrubs was estimated using the line-intercept method, and cover of bare ground, litter and all herbaceous species were estimated in ten microplots. Plants of all shrubs were classified into four size classes and counted in these microplots. Density was recorded for each species in the Cichorieae tribe of the Asteraceae in each microplot. Age and height of one randomly chosen sagebrush plant in each size class were determined from five microplots, and age was determined by counting annual growth rings. Soil samples were collected at each site and analyzed for percent organic matter, sand, silt and clay. We analyzed data with paired-sample t-tests, regression analysis and analysis of variance.

Regression models indicated that average post-fire time to full recovery of ssp. vaseyana canopy was 32 years, shorter for ssp. tridentata and much longer for ssp. wyomingensis. Height of the dominant sagebrush cohort recovered at similar rates with $100 \%$ recovery projected to be ca. 33 years for ssp. vaseyana. There was no difference in canopy or height recovery between prescribed fires and wildfires in stands of ssp. vaseyana. We found no relationship between sagebrush canopy recovery and annual precipitation, heat load or soil texture. We found no support for a relationship between grazing regime and sagebrush canopy recovery rate or that proximity to a seed source promotes faster recovery. Our results suggest that the majority of presettlement ssp. vaseyana stands would have been in early to mid-seral condition if we assume a mean fire interval of 25 years and a mean full recovery time of 32 years. Nearly all unburned control sagebrush macroplots were uneven-aged, indicating that recruitment was not limited to immediate post-fire conditions in any of the subspecies.

Average canopy cover of Artemisia tripartita did not increase following fire, and only $15 \%$ of plants survived the Winslow Fire of 2003. Age-class distributions indicate that many A. tripartita plants established from seed instead of sprouting following fire. Average density of the guild of subdominant shrubs, Chrysothamnus nauseosus, $C$. viscidiflorus and Tetradymia canescens, doubled after fire, although there were no statistically significant increases for any of the species taken alone.

Perennial graminoid cover was greater in burned than unburned control macroplots in stands dominated by $A$. tridentata ssp. vaseyana, and this difference was driven by changes in Agropyron spicatum rather than Festuca idahoensis. On average grass cover in burned $A$. tridentata ssp. vaseyana macroplots returned to control levels within 30 years after fire. Perennial grass cover averaged $13 \%$ higher in burned macroplots following prescribed fire but only $4 \%$ higher following wildfire.

Fire-induced changes in the canopy cover of forbs were small; there was only a marginally significant tendency for forb cover to be higher in burned macroplots compared to controls. The proportional change in forb cover following fire at sites dominated by $A$. tridentata ssp. vaseyana did not differ between prescribed fires and wildfires. 
There was no evidence for a change in the abundance of forbs in the Cichorieae Tribe of the Asteraceae, important foods for sage grouse brood rearing.

The results of our study have implications for management. Proper identification of sagebrush subspecies is an important precursor to any management activity because canopy cover of ssp. vaseyana stands will require an average of 32 years to recover, but those of ssp. wyomingensis may require a century or more. Many sagebrush steppe species may require a mosaic of stand ages; maintaining a mosaic of approximately half lateseral and half early-seral stands of ssp. vaseyana will require imposing a fire-return interval of about 50-80 years on all stands in the landscape. Only long fire-return intervals will allow stands dominated by ssp. wyomingensis to remain on the landscape in our study area. Managers cannot assume that stands of ssp. vaseyana on more mesic sites will recover faster or that sagebrush canopy will recover faster following prescribed fire compared to wildfire. Prescribed fire resulted in an average increase of $13 \%$ in grass canopy cover, so followed by light grazing, it may be a way of rejuvenating ssp. vaseyana stands. Prescribed fire or wildfire will induce only a small increase in the cover of forbs overall, and will have no effect on the abundance of plants in the Cichorieae. 


\section{AcKnowledgments}

Brian Hockett, Joe Casey, Brad Gillespe, Jim Roscoe and John Thompson of the Bureau of Land Management; Gary Hammond of Montana Fish, Wildlife \& Parks; and Larry Bradshaw, Harriet McKnight and Kevin Suzuki of BeaverheadDeerlodge National Forest helped us locate study sites. Many ranchers allowed us to conduct this research on their land. Bob Keane and Alisa Keyser of the Rocky Mountain Forest and Range
Experiment Station provided annual precipitation estimates for our study sites. Dave Roberts, Montana State University ecologist, generously donated his time to generate the plant association constancy/cover tables. Soil analyses were performed by the Soils lab at Montana State University. Coburn Currier contributed suggestions improving the manuscripts readability and formatted it to MTNHP specifications. 


\section{TABLe of Contents}

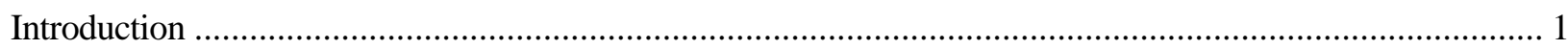

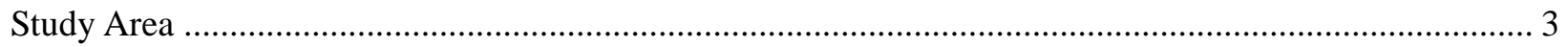

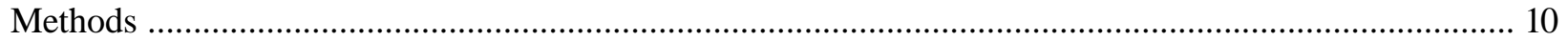

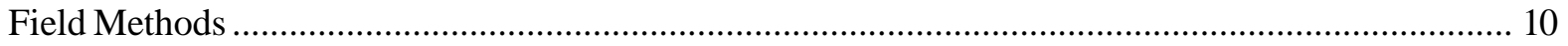

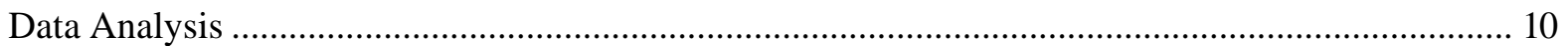

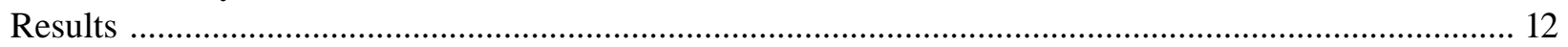

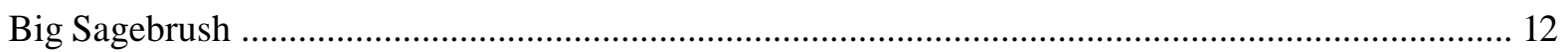

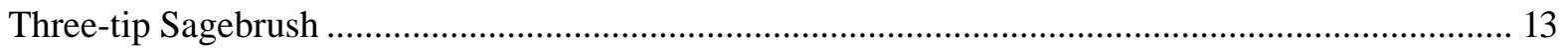

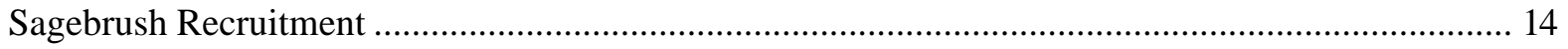

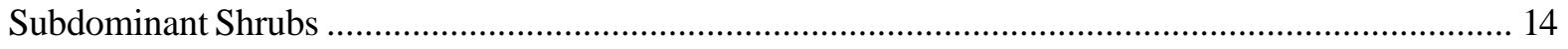

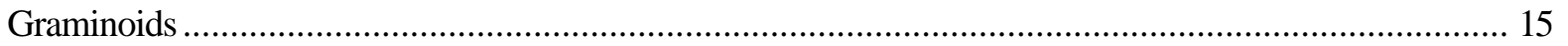

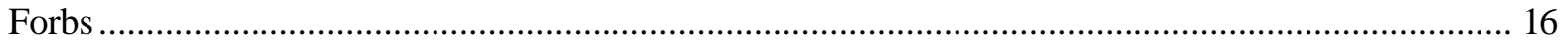

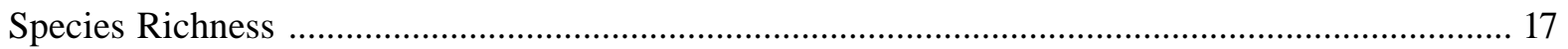

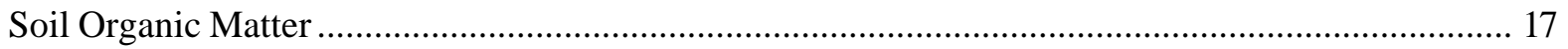

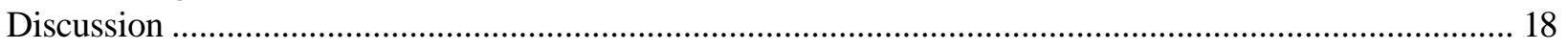

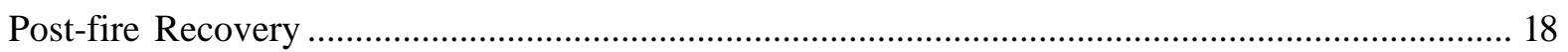

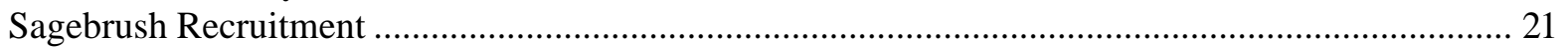

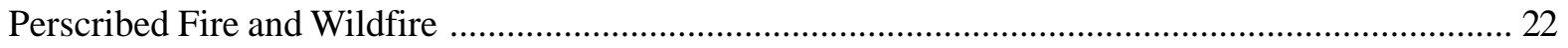

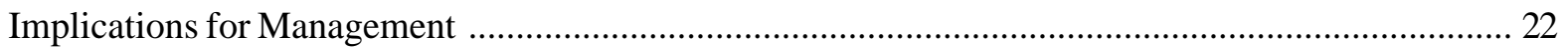

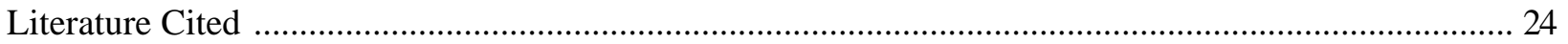

Appendix A. Global / State Rank Definitions

Appendix B. Descriptions of Artemisia tridentata spp. tridentata Series Plant Associations Found In The Study Area

Appendix C. Cover / Constancy Tables

Appendix D. Photos

\section{List OF FigurES}

Figure 1. Map of study area and plot locations in southwestern Montana ............................................ 4

Figure 2. Log-linear relationship between canopy cover of Artemisia tridentata ssp. vaseyana and time since fire for 28 prescribed fires and wildfires and linear relationship between

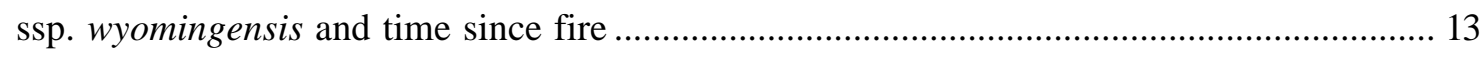

Figure 3. Relationship between canopy height of Artemisia tridentata ssp. vaseyana and time since fire for 23 prescribed fires and wildfires

Figure 4. Relationship between the number of sagebrush cohorts (even-age 2 yrs groups) and time since fire for 38 prescribed fires and wildfires among three subspecies of $A$. tridentata

Figure 5. Frequency distribution for recruitment of sagebrush plants in years following fire for four taxa ....

Figure 6. Mean perennial graminoid canopy cover (SE) in burned and unburned control macroplots for three subspecies of Artemisia tridentata ......................................................................... 16

Figure 7. Relationship between percent perennial graminoid canopy cover change (burned macroplot-control macroplot) and time since fire for Artemisia tridentata ssp. vaseyana ..... 16

Figure 8. Change in soil organic matter percentage for control - burned plot pairs ................................ 21 


\section{List OF TABLES}

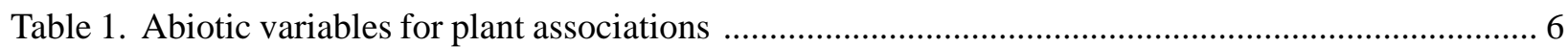

Table 2. Vegetation parameters of study area plant associations ........................................................... 7 


\section{INTRODUCTION}

Sagebrush steppe is the dominant vegetation type in southwest Montana; however, management strategies that promote the conservation of all species dependent on this vegetation type are just now being developed. Fire played a large role in structuring sagebrush ecosystems, creating a mosaic of stands of different size in various seral conditions (Lesica and Cooper 1997, West 1999). It is reasonable to assume that conservation of native species diversity will require a similar mosaic. For example, sage grouse (Centrocercus urophasianus) require barren areas for leks, relatively dense stands of medium height with an understory of bunchgrass for nesting (Klebenow 1969, Wallestad and Pyrah 1974, Aldridge and Brigham 2002) open stands with succulent forbs for brood rearing (Wallestad 1971, Klebenow 1972), and tall stands with a full canopy for wintering (Eng and Schladweiler 1972). Presumably sage grouse populations can be limited by the loss of any one of these habitat types (Connelly et al. 2000, Roscoe 2002). Brewer's sparrow (Spizella breweri) and sage thrashers (Oreoscoptes montanus) generally require sagebrush to breed and prefer extensive stands with relatively high cover (Wiens and Rottenberry 1981, Knick and Rottenberry 1995). However, Brewer's sparrows adapt to fire-caused mosaics by nesting in surviving patches of sagebrush (Bock and Bock 1987, Petersen and Best 1987). Pygmy rabbits (Brachylagus idahoensis) select tall, dense stands of sagebrush often associated with stream terraces (Weiss and Verts 1984, Katzner and Parker 1997, Rauscher 1997).

Agriculture, livestock grazing, herbicide treatments, prescribed fire and fire suppression have changed the amount, distribution and characteristics of sagebrush stands in southwest Montana (Lesica and Cooper 1997, Harrington 2002). Extensive stands of basin big sagebrush (Artemisia tridentata ssp. tridentata) on stream terraces have been converted to hay meadows. Livestock grazing has reduced bunchgrass cover in many stands. Fire suppression and livestock grazing have lowered fire frequency (Arno and Gruell 1983) and likely increased the proportion of dense-canopy mountain big sagebrush (A.tridentata ssp. vasseyana) stands.

Prescribed fire and herbicide application have been proposed as means to control the density of sagebrush stands (Klebenow 1972, Pyle and Crawford 1996, Olson and Whitson 2002); however, we have little knowledge of how vegetation changes with time as succession proceeds from immediate post-treatment to mature and old-growth stands. At what age do stands provide the most succulent forbs for sage grouse brood rearing, the best ${ }^{\sim}$ nesting cover for grouse, the best habitat for Brewer's sparrows and sage thrashers? Results from the few studies on sagebrush population dynamics are often contradictory. Sagebrush is considered the climax dominant species; however, it may require many years to re-establish on sites following fire (Harness and Murray 1973, Wambolt and Payne 1986, Wambolt et al. 2001), perhaps depending on soil texture (Gruell 1980). Fire often increases the abundance of grasses (Harness and Murray 1973, Wambolt and Payne 1986), but this may depend on species and fire severity (Wambolt et al. 2001). Late-seral sagebrush stands often have a dense canopy and are considered by many to be selfperpetuating in the absence of fire (Westoby et al. 1989, Laycock 1991). However, sagebrush dominance may decline with age when adequate precipitation favors residual bunchgrasses (Anderson and Inouye 2001). The age structure of sagebrush populations is likely to have a strong influence on the dynamics of these communities. Comprehensive management of sagebrush at the landscape scale cannot be accomplished without understanding how structural and compositional vegetation attributes change with time since disturbance.

The purpose of this study was to document how sagebrush communities change with age in southern Beaverhead and adjacent Madison counties. We inferred changes in understory composition, sagebrush height, cover and age-class distribution by sampling numerous burned and unburned pairs 
of stands of various ages in common sagebrush habitat types. Our sampling scheme also allowed us to determine whether soil texture and/or subspecies of Artemisia are associated with recolonization by sagebrush and rate of succession. Our findings have application throughout the
Beaverhead region because we sampled many stands over a large area. Our results can be integrated with existing knowledge of sensitive species habitat requirements to develop

management plans that use prescribed fire to create a mosaic that will meet management needs for conservation as well as livestock production. 


\section{STUdy ArEA}

Sampling occurred primarily in Beaverhead County, spilling over into southwestern Madison County as well (Fig.1), all of which is part of the Beaverhead Mountains Section (M332E, Nesser et al. 1997) of the Middle Rocky Mountains Steppe - Coniferous Forest - Alpine Meadow Province (Bailey 1995). From a Bureau of Land Management perspective this area is included wholly within Major Land Resource Areas 43 (Northern Rocky Mountains) and 44 (Northern Rocky Mountain Valleys) and sampling included the very wet extreme of the 9-14 in. zone, the 14-19 and 19 in. plus precipitation zones (Natural Resource Conservation Service State Office 1998). Elevations range from 1,615 to $3,230 \mathrm{~m}$ (5,300 to $10,600 \mathrm{ft}$.) with the mountains being almost exclusively block faulted and formed in igneous, sedimentary and metasedimentary rocks. Despite the predominance of high elevations, forest vegetation is considerably less extensive than Artemisia spp. (sagebrush)dominated shrublands (shrub-steppe) and grasslands that are comprised predominantly of tussock-forming graminoids.

The predominance of steppe and shrub-steppe within the study area is a consequence of the relatively low annual precipitation, which varies from somewhat less than $25 \mathrm{~cm}$ (10 in.) in valley locations to upwards of $90 \mathrm{~cm}$ (35 in) along the mountain crests. Virtually all of the study area can be said to be in the rain shadow of ranges to the west. Precipitation patterns, based on the Dillon recording station, show a strong peak in the biologically important (contributing to soil recharge in critical growth period) April-June quarter with a long-term average of $14.9 \mathrm{~cm}$ (5.87 in.), which is 44 $\%$ of $33.75 \mathrm{~cm}$ (13.29 in.) average total annual precipitation; April-June percentages for the following stations, Ennis (51\%), Virginia City (41\%), Lakeview (34\%) indicate this pattern holds throughout the study region. This spike in precipitation contributes to soil water recharge critical for spring growth and seed set. The last seven years have been droughty throughout the region with total annual precipitation being from 97 to $60 \%$ of the long-term average (based on the Dillon station). However, for the Dillon station and considering just the critical April-June period, two of the seven years experienced greater than average precipitation and the years 2003 and 2004, when the study was conducted, were 79 and $82 \%$ of the long-term average. Though this decreased precipitation doubtless affected the vegetation, there was not nearly the impact that might have been expected based on total annual precipitation, which was only 62 and $70 \%$ of average for these years, respectively. April 2003 precipitation for the study region was about twice average but May and June precipitation was less than half the long-term average and the normally reliable convectional storms of July did not materialize leading to earlier than normal curing of grasses and forbs and premature curtailing of field sampling.

We had little information on the burns other than the knowledge that a burn resulted from wildfire (natural of man-caused ignition) or a prescribed burn and time (year) of ignition. Attempts at characterizing fire intensity, which might have been an important explanatory variable, were frustrated by the advanced age of some burns and the consequent obscuring of significant details in the intervening years before sampling. A small minority of burned sites had a few Artemisia (sagebrush) specimens that escaped fire but most fires were of sufficient intensity to burn stems to a height of 0.5 to $2 \mathrm{dm}$. The presumed high intensity fires consumed all of the above-ground portion of stems and in the most severe cases actually dished-out the stem below the ground surface. Considerable ground-level inspection was conducted on the oldest burns to discriminate burned from control areas.

Fires of presumed lesser intensity (usually prescribed burns) left secondary and tertiary branches on many of the standing stems, but all the fine material had been consumed, and the specimens were dead.

All three subspecies of big sagebrush occur in distinctive elevational-physiographic positions in our study area, ranging from the lowest valleys to just short of the alpine zone at about 9,600 ft. A. tridentata ssp. wyomingensis (Wyoming big sagebrush) exhibits the lowest growth form of this 
Figure 1. Map of study area and plot pair locations. Plot symbols represent burned plots, control plots are nearby.
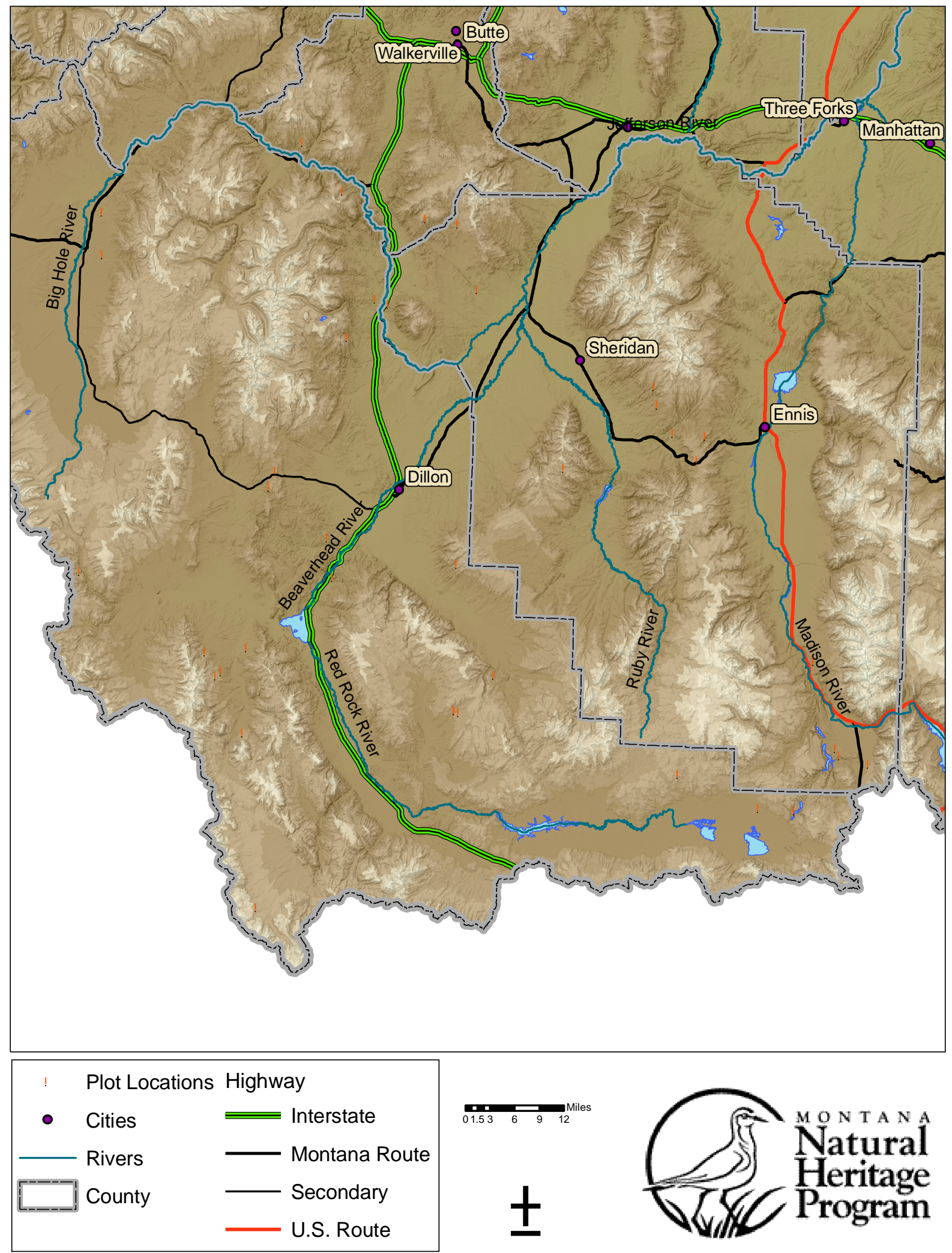
group, commonly attaining heights of 5 to $9 \mathrm{dm}$ (20 to 36 in.) with the oldest specimens on the most mesic sites slightly exceeding $1 \mathrm{~m}$ (39 in). In addition to minor morphological and chemotaxonomic differences this taxon is distinctive for occurring on the most xeric sites of all big sagebrush taxa where the annual precipitation ranges, according to Winward (2004), from 18 to 30 cm (7-11 inches). Modeled annual precipitation (Thornton et al. 1997, Table 1) associated with study locations ranged from 13.4 to 15.3 in. (34.0 to $38.9 \mathrm{~cm}$ ), averaging 14.2 in $(36.1 \mathrm{~cm})$. According to Winward (2004) in the Pacific Northwest and Great Basin portions of its range this subspecies occurs from $<300$ to $1,800 \mathrm{~m}(<1,000-6,000 \mathrm{ft})$. Study area sampling locations ranged from 1,800 to 2,035 m (5,910 to 6,670 ft.), occurring predominantly in valley locations on old terraces with one site typifying xeric west-facing, steeper slopes. Soil texture exhibited slight variation, ranging from loams to silt loams and sandy clay loams. According to the Ecological Sites Key developed by the Natural Resource Conservation Service (NRCS, Draft 2/9/2005) our ssp. wyomingensis sample sites are predominantly Silty (Si) and Silty Steep (SiSp). It is not surprising that within the study area ssp. wyomingensis sites are uncommon, compared to $A$. tridentata spp. vaseyana (mountain big sagebrush); this relative rarity reflects not so much that spp. wyomingensis is at the extremes of its range but rather that so much of the study area is higher elevation (greater precipitation) competitively favoring ssp. vaseyana.

Control plot vegetation of the ssp. wyomingensis sites closely approximates the description given by Mueggler and Stewart (1980) for the Artemisia tridentata / Agropyron spicatum Habitat Type. They note that the big sagebrush for their plots representing this H.T. almost certainly was $A$. tridentata ssp. wyomingensis); this type is now recognized in the National Vegetation Classification System (NVCS) as A. tridentata ssp. wyomingensis / Pseudoroegneria spicata (Anderson et al. 1998, Cooper et al. 1999). Average ssp. wyomingensis cover in our control plots is $14 \%$ whereas Muegggler and Stewart (1980) found 15\%. The representation of other shrubs, Ericameria (= Chrysothamnus) nauseosa (rubber rabbitbrush), C. viscidiflorus (yellow rabbitbrush), and Tetradymia canescens (spineless horsebrush), and subshrubs, Artemisia frigida (prairie sagewort, fringed sagebrush), Gutierrezia sarothrae (broom snakeweed), and Opuntia spp. (pricklypear) also follows the description of Mueggler and Stewart (1980).

The perennial grass component averages 25\% cover (Table 2) and is strongly dominated by $P$. spicata (bluebunch wheatgrass); Mueggler and Stewart plots express a similar dominance of $P$. spicata but its cover and total perennial graminoid cover is higher, which is to be expected given their study's emphasis on characterizing "undisturbed" vegetation. The forb component in our stands is comparatively depauperate with only Phlox hoodii (Hood's phlox) and Antennaria rosea (rosy pussytoes) consistently present in greater than trace amounts. Two control plots keyed to a relatively uncommon plant association, $A$. $t$. ssp. wyomingensis / Festuca idahoensis (Wyoming big sagebrush / Idaho fescue), that has been described only from southeastern Oregon (Doescher et al. 1986); generally Idaho fescue is associated with more mesic portions of the moisture gradient and has not, with the exception of the description of Doescher et al. (1986), been reported to occur in combination with the relatively xeric Wyoming big sagebrush. In accordance with expectations, these plots have lower sagebrush, graminoid and forb cover than any of the component plots of the ssp. vaseyana / F. idahoensis - P. spicata plant association (Mountain big sagebrush / Idaho fescue - bluebunch wheatgrass), the type that is its presumed closest ecological analogue within the study area.

Artemisia tridentata ssp. tridentata (basin big sagebrush)-dominated sites are found on deep, well-drained soils where soil moisture remains available for plant growth into late August, even though air temperatures are relatively warm (Winward 2004). Within the study area this subspecies was sampled from the lowest elevations at 1,630 m (5350 ft.) to almost 2,105 m (6,900 ft.), always associated with low gradient alluvial terraces having deep, rock-free, relatively coarsetextured soils (Table 1). Soil texture ranged from 
Table 1. Abiotic variables for plant associations sampled.

\begin{tabular}{|c|c|c|c|c|c|c|c|c|c|}
\hline $\begin{array}{l}\mathrm{B} \\
\text { or } \\
\mathrm{C}^{1}\end{array}$ & $\begin{array}{l}\text { Elevevation } \\
\text { (ft.) }\end{array}$ & $\begin{array}{l}\text { Heat- } \\
\text { load } \\
\text { Index }\end{array}$ & $\begin{array}{l}\text { Slope } \\
(\%)\end{array}$ & $\begin{array}{c}\text { Precipitation } \\
\text { (cm) }\end{array}$ & Soil Textural Class ${ }^{3}$ & Sand \% & Silt \% & Clay \% & $\begin{array}{c}\text { Organic Matter } \\
\%\end{array}$ \\
\hline \multicolumn{10}{|c|}{ Artemisia tridentata ssp. wyomingensis / _ $(n=6)^{4}$} \\
\hline B & $6240(5910-6665$ & $85(79-93)$ & $16(2-34)$ & 37.3 (34.1-41.5) & $\operatorname{Im}(3) ;$ si Im (2); sy cy Im (1) & $40(26-46)$ & $40(28-52)$ & $20(9-29)$ & $4.0(3.2-5.1)$ \\
\hline C & $6200(5910-6670)$ & $88(80-95)$ & $16(8-36)$ & $36.7(34.0-41.5)$ & $\operatorname{Im}(3) ;$ si $\operatorname{Im}(1)$; sy cy $\operatorname{Im}(1)$ : cy $\operatorname{Im}(1)$ & $37(20-48)$ & $40(28-52)$ & $23(19-27)$ & $3-4.8)$ \\
\hline \multicolumn{10}{|c|}{ Artemisia tridentata ssp. tridentata / _ $(n=4)^{4}$} \\
\hline B & $6025(5140-6860)$ & $91(90-92)$ & $2(0-4)$ & $41.5(28.2-63.4)$ & Imy sa (1); sy Im (2); sa (1) & $70(57-85)$ & $20(12-30)$ & $10(7-13)$ & $3.7(1.7-6.0)$ \\
\hline C & $6030(5240-6855)$ & $91(90-93)$ & $4(0-8)$ & $41.5(29.2-63.4)$ & Im (1); Imy sa (1); sa Im (1); sa (1) & $68(53-89)$ & $21(4-34)$ & $11(7-16)$ & $4.4(1.7-8.6)$ \\
\hline \multicolumn{10}{|c|}{ Artemisia tridentata ssp. vaseyana / Festuca idahoensis - Geranium viscossisimum $(n=6)$} \\
\hline B & $6685(6450-6920)$ & $90(82-95)$ & $14(3-24)$ & $61.2(46.9-74.3)$ & $\operatorname{Im}(4) ; \operatorname{silm}(1)$ & $38(27-47)$ & $45(38-50)$ & $17(15-21)$ & $9.1(5.1-11.1)$ \\
\hline C & $6630(6560-6925)$ & $88(74-95)$ & $14(4-29)$ & $63.3(47.3-74.4)$ & $\operatorname{Im}(5)$ & $36(29-45)$ & $44(42-48)$ & $20(13-25)$ & -9.7) \\
\hline \multicolumn{10}{|c|}{ Artemisia tridentata ssp. vaseyana / Festuca idahoensis - Achnatherum occidentale $(n=8)$} \\
\hline B & $7110(6715-7600)$ & $91(80-98)$ & $16(10-27)$ & $56.4(47.7-65.7)$ & $\operatorname{Im}(4) ; \operatorname{Imy}$ sa (1); sa Im (3) & $56(42-87)$ & $31(6-48)$ & $13(7-20)$ & $6.85(3.2-9.8)$ \\
\hline C & $7110(6745-7600)$ & $92(84-98)$ & $14(5-23)$ & $56.4(47.8-65.3)$ & Im (3); Imy sa (1); sa Im (4) & $56(36-87)$ & $31(6-50)$ & $13(7-17)$ & $(4.0-13.2$ \\
\hline \multicolumn{10}{|c|}{ Artemisia tridentata ssp. vaseyana / Festuca idahoensis - Carex filifolia $(\mathrm{n}=2)$} \\
\hline B & 6055 (6050-6060) & $89(88-91)$ & $5(0-9)$ & $41.3(41.2-41.5)$ & $\operatorname{Im}(1) ;$ cy $\operatorname{Im}(1)$ & $37(29-45)$ & $36(28-44)$ & $27(27-27)$ & 5.2-5.2) \\
\hline C & $6060(6050-6070)$ & $87(86-91)$ & $4(0-8)$ & $41.2(40.9-41.5)$ & $\operatorname{Im}(1) ;$ cy $\operatorname{Im}(1)$ & $37(33-41)$ & $36(38-44)$ & $22(21-23)$ & $9.1(4.4-13.8)$ \\
\hline \multicolumn{10}{|c|}{ Artemisia tridentata ssp. vaseyana / Festuca idahoensis - Pascopyrum smithii $(\mathrm{n}=3)$} \\
\hline B & $6970(6935-7200)$ & $87(85-90)$ & $6(2-9)$ & $50.5(41.0-61.9)$ & $\operatorname{Im}(1) ;$ cy $\operatorname{Im}(1) ;$ sy cy $\operatorname{Im}(1)$ & $43(32-55)$ & $32(24-36)$ & $25(21-32)$ & $6.2(4.1-9.2)$ \\
\hline C & $6975(6725-7220)$ & $87(86-90)$ & $7(2-9)$ & $48.8(41.8-62.2)$ & $\operatorname{Im}(2) ; c y \operatorname{Im}(1)$ & $36(34-39)$ & $37(32-40)$ & $27(21-33)$ & $6.1(4.1-9.2)$ \\
\hline \multicolumn{10}{|c|}{ Artemisia tridentata ssp. vaseyana / Festuca idahoensis - Pseudoroegneria spicata $(\mathrm{n}=10)$} \\
\hline B & $6905(6440-7800)$ & $87(68-93)$ & $20(2-40)$ & $46.9(40.3-54.6)$ & $\operatorname{Im}(6) ;$ cy $\operatorname{Im}(1) ;$ sy $\operatorname{Im}(1) ;$ sy cy $\operatorname{Im}(1) ; \operatorname{Imy}$ sa (1) & $46(34-79)$ & $35(14-42)$ & $19(7-28)$ & $6.7(2.3-10.7)$ \\
\hline $\mathrm{C}$ & $6965(6400-7885)$ & $87(69-94)$ & $22(5-46)$ & $47.8(40.3-53.9)$ & $\operatorname{Im}(6) ;$ si Im (1); sy Im (2); Imy sa (1) & $47(31-81)$ & $35(12-52)$ & $18(7-25)$ & $7.1(3.8-13.2)$ \\
\hline
\end{tabular}

${ }^{1} \mathrm{~B}$ row indicates average and range for a given variable for burned plots within a type; $\mathrm{C}$ row indicates same for control plots.

2 Heat-load Index (McCune and Keon 2002); value computed for a given latitude, slope and aspect; maximum shifted from south $\left(180^{\circ}\right)$ to southw est $\left(225^{\circ}\right)$ slopes

${ }^{3}$ Terms used in soil textural classes abbreviated as follow s: cy=clay; Im=loam; sa=sandy; si=silty; sy=sandy;

${ }^{4}$ Blank space behind the slash indicates that plots have been summarized by dominant Artemisia because numbers w ere insufficient to stratify by plant association. 
Table 2. Vegetation parameters of study area plant associations.

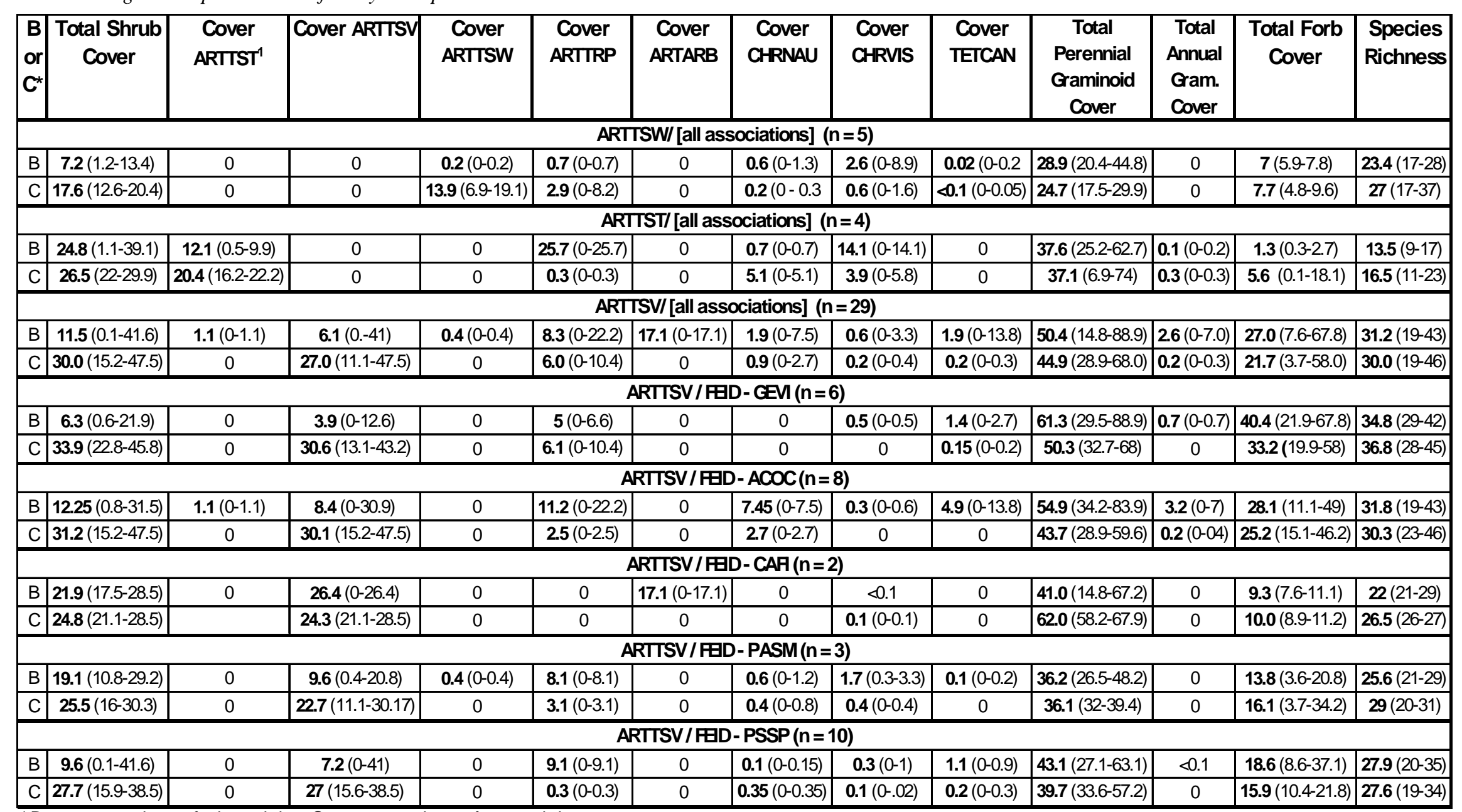

${ }^{*} \mathrm{~B}=$ average and range for burned plots, $\mathrm{C}=$ average and range for control plots

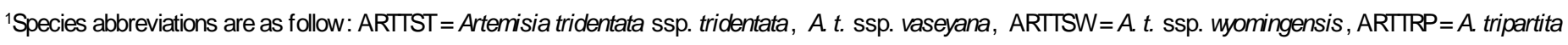

ARTARB = A arbuscula, $\mathrm{C}-\mathrm{PNAU}=$ Chrysothamnus nauseosus, $\mathrm{CHRVIS}=$ Chrysothamnus viscidiflorus, TETCAN $=$ Tetradymia canescens 
sands, loamy sands and sandy loams to the sandy side of loam (Table 1) and was distinctly coarser than that typifying sites occupied by the other two subspecies. The average annual precipitation associated with these sites ranges from $29.2 \mathrm{~cm}$ (11.5 in.) to $63.4 \mathrm{~cm}$ (24.9 in). Given their coarsetextured soils, relatively low precipitation and their landscape position we speculate that some of these sites are subirrigated (otherwise they are well within the environmental parameters of ssp. wyomingensis). NRCS-defined Ecological Sites encompassed by our sampled stands of this subspecies are split between Sands (Sa) and Sandy (Sy) and occur in both the 9 to 14 and 14 to 19 inch precipitation zones.

We found two plant associations, A. tridentata ssp. tridentata / Pascopyrum smithii (western wheatgrass) and A. tridentata ssp. tridentata / Hesperostipa comata (needle-and-thread) dominated by this sagebrush subspecies. The ssp. tridentata / $\mathrm{H}$. comata association is quite uncommon, having been described only for the Montana's Centennial Sandhills (Cooper et al. 1999) and is not cited in the NVCS (Anderson et al. 1998) and the ssp. tridentata / P. smithii association has been described from only Montana and Colorado and is rated as G3 by NatureServe (2004). Because of its landscape position and soils suitable for agriculture much of the original ssp. tridentata habitat has been altered by cultivation or other land modification, causing proportionately more post-settlement acreage loss and compositional alteration than experienced by any of the other sagebrush taxa in southwestern Montana. The foregoing observations and the fact that Mueggler and Stewart (1980) focused on U. S. Forest Service lands of higher elevations, generally above the majority of ssp. tridentata distribution, in all likelihood explains their not sampling or describing any communities characterized by this subspecies.

Mature ssp. tridentata is usually at least $11 \mathrm{dm}$ (44 in.) tall and ranges to $14 \mathrm{dm}$ (55 in.) on control stand plots. Total shrub cover ranged between 22 and $30 \%$, averaging 27\%; ssp. tridentata cover ranged between 16 and 27\% (Table 2). The only other shrubs consistently present and contributing more than a trace of cover are Ericameria (= Chrysothamnus) nauseosa (rubber rabbitbrush) and C. viscidiflorus (green or yellow rubber rabbitbrush). The association of appreciably high coverages (7 to $74 \%$, average $40 \%$ ) of rhizomatous wheatgrass with these sandy soils indicates that this grass may be Elymus lanceolatus (=Agropyron dasystachyum, thickspike wheatgrass). Elymus lanceolatus, even when sexually mature, is morphologically nearly indistinguishable from Pascopyrum smithii. Though the two are considered by some to be ecological analogues, $P$. smithii evidences a strong affinity for heavytextured soils, at least in eastern Montana (Heidel et al. 2001, Cooper et al. 2001, Vanderhorst et al. 1998) whereas the same response has not been shown for E. lanceolatus. We have conservatively chosen to refer to this rhizomatous wheatgrass characterized plant association by its established name A. tridentata ssp. tridentata / P. smithii despite evidence that it may well be dominated by E. lanceolatus in some locations; only intensive collecting and taxonomic analysis can resolve the confusion. The nearly pure sands ( $89 \%$ sand) of the Centennial Sandhills are extremely well drained and support needle-and-thread grass as the undergrowth dominant; a rhizomatous wheatgrass, most probably E. lanceolatus, was present, but not indicative at $1 \%$ cover. With the exception of sporadic high-cover patches of Balsamorhiza sagittata (arrowleaf balsamroot) in the Centennial Valley stand, the forb cover (and diversity) of these two plant associations is depauperate. Although we can substantiate Winward's (2004) characterization of this subspecies as being associated with more productive sites than Wyoming big sagebrush, this was not true regarding Winward's evidence of greater species diversity as well. Based on our limited sample, overall species diversity averages 17 on basin big sagebrush sites and 27 on those with Wyoming big sagebrush dominant.

Shrubland communities dominated by A. tridentata ssp. vaseyana (mountain big sagebrush) are by far the most extensive vegetation type in southwestern Montana. Winward (2004) reports it to have a rather conservative elevation range of 2,600 to 3050 m ((8,500 to $10,000 \mathrm{ft}$.) but within southwestern Montana we have noted it to range from 1,830 to 
2,925 m (6,000 to 9,600 + ft.) and our sample plots ranged from 1,845 to 2,340 m (6050 to $7675 \mathrm{ft}$.). Within southwestern Montana ssp. vaseyana is found from flats to steep slopes and evidences no particular aspect preference. It is found primarily on medium to coarse textured soils (loams, silt loams), which may more reflect the substrates available and not a texture preference; the finer textured soils of basins occurring lower in the landscape lie beyond this subspecies' moisture/ temperature requirements. It did occur on loamy sands (just shy of being true sands) as the coarsest material represented and clay loams on the finetextured side. Given this broad spectrum of abiotic site parameters, it follows that a conspicuous and ecologically differentiating undergrowth exists. This subspecies is phenologically plastic with mature specimens ranging from a somewhat stunted subshrub of 2-3 dm height in subalpine environments to over a meter tall on sites with more favorable temperatures and soil moisture.

Mueggler and Stewarts'(1980) publication detailing rangeland habitat types (h.ts.) of western Montana recognizes only one Mountain big sagebrushdominated h.t. unit, A. tridentata ssp. vaseyana / Festuca idahoensis, and one phase thereof, Geranium viscossisimum (sticky geranium), which is characteristic of the more mesic sites. Extensive subsequent field sampling by the Montana Natural Heritage Program (Cooper et al. 1999) resulted in delineating eight plant associations in which ssp. vaseyana is the dominant/codominant shrub component and of these eight, five are represented in the stands sampled for this project: A. tridentata ssp. v. / F. idahoensis Pascopyrum smithii (western wheatgrass), A. tridentata ssp. v. / F. idahoensis -

Pseudoroegneria spicata (bluebunch wheatgrass), A. tridentata ssp. v. / F. idahoensis - G. viscossisimum (sticky geranium), A. tridentata ssp. v. / F. idahoensis - Achnatherum occidentale (western needlegrass), A. tridentata ssp. v. / F. idahoensis - Carex filifolia (theadleaf sedge). Though all five of the above listed types are based on existing vegetation, they also have a strong bias toward potential vegetation, since only the least disturbed vegetation and late seral stages were used in their definition and description. NRCS defined Ecological Sites encompassed by ssp. vaseyana-defined control stands are distributed as follows: Sands (Sa, 2); Sandy (Sy, 3); Sandy (Sy, 3); Silty (Si, 11); Silty Steep (SiSp, 6); Clayey (Cy, 2). None of the ssp. vaseyanacharacterized plant associations occurred on just one Ecological Site and conversely a given Ecological Site could be represented across several plant associations (Table 1).

Mueggler and Stewart (1980) reported elevation and precipitation envelopes of 1,830 to $2,440 \mathrm{~m}$ (6,000 to 8,000 ft.) and 40 to $75 \mathrm{~cm}(15.7-29.5 \mathrm{in}$.) for their broadly defined A. tridentata / F. idahoensis type, which are similar to our findings, 1,845 to $2,405 \mathrm{~m}$ (6050 to $7,885 \mathrm{ft}$.) and 40.3 to 74.3 cm (15.8 - 29.3 in.) (Table 1). Effective soil moisture is the primary driving variable influencing composition and productivity in semi-arid shrublands (Billings 1949, Burke et al. 1989, Hironaka et al. 1973, West 1979). Although we measured and estimated surrogates of this driver (including elevation, interaction of slope and aspect, soil texture, landform, slope position and a precipitation model), no measure integrates these factors as well as potential vegetation (Daubenmire 1976).

Appendix B includes descriptions of these ssp. vaseyana-dominated communities. As explained in the methods section, plots representing these plant associations were combined at the series level to create a generalized statistical model; there was not an adequate time-series of plots to construct models based on even one of the $A$. tridentata ssp. vaseyana plant associations.

Appendix C includes a table with the proportion of stands in which a species occurs and the average species cover. It is stratified by plant association, for both control and burned plots. Appendix D has a photographic record of typical burned sites and control vegetation. 


\section{Methods}

\section{Field Methods}

We sampled 38 sites dominated by Artemisia tridentata ssp. wyomingensis, ssp. vasseyana or ssp. tridentata in Beaverhead and Madison counties below 8,000 ft in elevation (Fig. 1, Appendix B) in June and July of 2003 and 2004. Sites were stratified by county, ignition source (prescribed vs wild), subspecies and age and randomly selected from a pool of more than 100 prescribed burns and wildfires provided by the Dillon Office of the Bureau of Land Management, Beaverhead-Deerlodge National Forest and Montana Department of Fish, Wildlife and Parks. We avoided sites with a history of herbicide application.

At each site we subjectively located one sample plot that appeared to represent the majority of the burned area. Sample macroplots were $1000 \mathrm{~m}^{2}$ (20 m X 50 m). We located a "control” sample macroplot as close to the burn as possible in adjacent unburned vegetation with similar aspect, slope and soil as the burned plot (Appendix B). These unburned "control" macroplots plots were not true controls because they were not randomly assigned prior to the fires; however, they act as controls by representing what burned plots would be like, had they not burned. Burned macroplots were always located within $300 \mathrm{~m}$ or less from the sagebrush seed source of the unburned control and always in the same grazing pasture. We have no way of accurately assessing immediate post-fire grazing regimes; however, we did take care to locate sample plots well away from water developments and fence lines to help insure that grazing pressure was not above average for the pasture.

Canopy cover (Daubenmire 1959) of shrubs was estimated using the line-intercept method along five evenly-spaced, parallel 20-m transects originating from the 50-m macroplot baseline (MuellerDombois and Ellenberg 1974). Plants of all shrubs were classified into four size classes: seedlings ( $<10$ $\mathrm{cm}$ high), juvenile ( $>10 \mathrm{~cm}$ high and $<1 \mathrm{~cm}$ diameter), small mature (1-3 cm diameter), large mature ( $>3 \mathrm{~cm}$ diameter) and counted in ten 3- $\mathrm{m}^{2}$ circular (radius $=1 \mathrm{~m}$ ) microplots located at the 5meter and 15-meter marks along the five transect lines. Canopy cover (Daubenmire 1959) of all vascular plant species, bare ground and litter were estimated to the nearest $10 \%$ in these same ten microplots. Density was recorded for each species in the Cichorieae tribe of the Asteraceae in each microplot.

Age and height of one randomly chosen sagebrush plant in each size class were determined from alternate microplots (a total of five). Sagebrush plants were severed at ground level, and we counted annual growth rings in the field with a 10X hand lens (Ferguson 1964). It was more difficult to accurately measure the age of plants greater than 30 years old, especially plants of $A$. tripartita. We noted age measurements for which we were not confident. When one or more size classes were not represented in all five sample plots we sampled plants outside the microplots to insure that we had at least three estimates for each size class in each macroplot. We failed to measure sagebrush heights at seven of the sites.

Three haphazardly located 50 cc soil samples were collected from the 0-10 cm depth in each macroplot. Samples for each macroplot were combined and analyzed for particle size distribution and percent organic matter by loss on ignition.

In September 2004, one macroplot was established in a mixed stand of $A$. tridentata ssp. vaseyana and A. tripartita on the north side of the Centennial Valley. The Winslow Fire, a hot wildfire, burned this stand in August 2003. We recorded the number of dead and resprouting $A$. tripartita plants in ten 3- $\mathrm{m}^{2}$ circular microplots. A. tripartita remnants were readily discriminated from those of $A$. tridentata ssp. vaseyana on the basis of stem morphology.

\section{Data Analysis}

We define sagebrush recovery as the mean sagebrush canopy cover or height for the burned 
macroplot divided by that of the unburned control macroplot. Height of the dominant cohort (size class with the most canopy cover) was used to evaluate changes in stand height. Rate of sagebrush recovery for canopy and height is recovery divided by the number of years since fire. We examined differences in sagebrush age-class distribution using the coefficient of variation (cv) for measured ages in each macroplot. Stands that approached having only one or two age classes have a relatively small $\mathrm{cv}$ compared to those with three or more cohorts present. We define a sagebrush cohort as all plants within a five-year age span separated by other cohorts by two or more years. Cohorts that survived the fire were not counted in burned macroplots. Species richness is the number of species recorded in the ten microplots and the intercept lines for each macroplot.

We hypothesized that recruitment and other aspects of sagebrush recovery would depend on the relative aridity of a site, in turn dependent on precipitation as well as potential evapotranspiration. The latter will depend primarily on slope and aspect. These two variables have been integrated into an index of heat loading by McCune and Keon (2002). Mean annual precipitation for each site was estimated using DAYMET, a model that integrated elevation and other aspects of local terrain with weather station data for the past eighteen years (Thornton et al. 1997). We regressed the number of sagebrush plants recruited on seasonal precipitation $($ winter $=$ January+February+March, spring =
April+May+June, etc.) recorded at Dillon for each of the past 35 years to examine the effect of interannual climate changes over our study area.

We used paired-sample t-tests to assess the differences between burned and unburned control macroplots in sagebrush canopy cover and height, perennial grass canopy cover, forb canopy cover, density of other shrubs and percent soil organic matter. We used linear regression analysis to model the recovery of sagebrush height and canopy cover and grass canopy cover with time since fire.

Models were constrained to have the regression line pass through the origin. Regression analysis was also used to test the association between time since fire and change in forb cover and soil organic matter and to test the association between sagebrush canopy recovery rate and the abiotic site factors, precipitation, soil texture (\% sand) and heat load index. We used analysis of variance (ANOVA) to assess the differences between subspecies and season of fire of $A$. tridentata in height and canopy recovery with time since fire as a covariate in the models. Recovery and recovery rates were log-transformed for these analyses. We also tested the effects of fire season (prescribed fire in cool seasons versus wildfire) on grass and forb canopy cover, soil organic matter and sagebrush age-class distribution with ANOVA. Recovery with time since fire was a covariate in these models to account for successional changes unrelated to the dependent variables. We present means followed by \pm standard errors. 


\section{RESULTS}

\section{Big Sagebrush}

We sampled six sites dominated by A. tridentata ssp. wyomingensis. Time since fire ranged from eight to 23 years with a median of 15 years in the burned macroplots. Mean canopy cover of this subspecies in unburned control macroplots was $15 \pm 2 \%$. Mean height of this subspecies dominant cohort in unburned controls was $61 \pm 7 \mathrm{~cm}$. We sampled 28 sites dominated by subspecies $A$. tridentata ssp. vaseyana. Time since fire in burned macroplots ranged from three to 34 years with a median of 16 years. Mean canopy cover of this subspecies in unburned control macroplots was $28 \pm 2 \%$. Mean height of the dominant sagebrush cohort in unburned controls was $76 \pm 4 \mathrm{~cm}$. We sampled 4 sites dominated by A. tridentata ssp. tridentata. Time since fire ranged from 11 to 30 years with a median of 23.5 years. Mean canopy cover of this subspecies in unburned control macroplots was $20 \pm 2 \%$. Mean height of the dominant sagebrush cohort in unburned controls was $131 \mathrm{~cm}(\mathrm{SE}=6 \mathrm{~cm})$. Across all big sagebrush subspecies and cohorts fire resulted in an almost complete loss of canopy. Mean canopy cover for recently burned macroplots ( $<10$ years, $\mathrm{N}=10$ ) for all big sagebrush subspecies combined was $3 \%$ with a median of less than $1 \%$, while both mean and median were $26 \%$ for control plots.

The three subspecies of Artemisia tridentata occupy different abiotic environments. Mean annual precipitation for ssp. vaseyana sites was $530.2 \mathrm{~mm}$, greater than for either ssp. wyomingensis (380.1 mm) or ssp. tridentata $(415 \pm 8 \mathrm{~mm})$ sites $\left(\mathrm{F}_{1,35}>5.3, \mathrm{P}=0.027\right)$. Mean annual precipitation between the latter two subspecies did not differ $\left(\mathrm{F}_{1,34}=0.3, \mathrm{P}=0.57\right)$. Percent sand was a good index of overall soil texture as it was strongly associated with both \% clay $(r=-0.72)$ and silt $(r=-0.92)$. Mean percent sand was $70 \pm 7 \%$ for ssp. tridentata sites, greater than either ssp. wyomingensis (39 $\pm 3 \%$ ) or ssp. vaseyana $(47 \pm 3 \%)$ sites $\left(F_{1,35}>11.8, P=0.002\right)$. Soils did not differ between ssp. wyomingensis and ssp. vaseyana sites $\left(\mathrm{F}_{1,35}=1.5, \mathrm{P}=0.32\right)$. Heat load index did not differ among sites for the three subspecies $\left(\mathrm{F}_{2,35}=1.2, \mathrm{P}=0.32\right)$.

The recovery of canopy cover of $A$. tridentata ssp. vaseyana fit a log-linear regression model better than a linear model. A log-linear model for ssp. vaseyana accounted for $76 \%$ of the variation, while a linear model explained 58\%. On average, stands of ssp. vaseyana are expected to be $100 \%$ recovered after 32 years (Fig. 2). A linear model provided the best fit for recovery of ssp.

wyomingensis, explaining $52 \%$ of the variation with full recovery expected to take more than 200 years (Fig. 2). However, we have little confidence in the ssp. wyomingensis model because there were only six sample plots, and four had no sagebrush cover after as many as 17 years. Recovery of ssp. tridentata could not be modeled with only four samples. The mean canopy recovery rate (\%change/time since fire) for ssp. vaseyana was $1.6 \pm 0.3 \%$ per year, more than ten times as great as for ssp. wyomingensis $(<0.1 \%$ year \pm 0.4$)\left(\mathrm{F}_{1,34}=\right.$ 29.5, $\mathrm{P}<0.001)$. Mean recovery rate for ssp. tridentata was $3.0 \pm 1.3 \%$ per year, greater than the other two subspecies $\left(\mathrm{F}_{1,34}=7.3, \mathrm{P}=0.011\right)$. Recovery of ssp. vaseyana canopy cover did not differ between wildfire and prescribed fire $\left(\mathrm{F}_{1,25}=\right.$ $2.2, \mathrm{P}=0.15$ ). Height of the dominant sagebrush cohort over all subspecies recovered at similar rates $\left(F_{2,27}=0.85, P=0.44\right)$, with $100 \%$ recovery projected to be ca. 33 years for ssp. vaseyana (Fig. 3). There was no difference in height recovery between prescribed fires and wildfires in stands of ssp. vaseyana after accounting for age differences $\left(\mathrm{F}_{1,20}=0.1, \mathrm{P}=0.72\right.$; Fig. 3). Total canopy cover of perennial grasses, as well as cover of Festuca idahoensis or Agropyron spicatum in unburned control macroplots (a surrogate of grazing intensity) was not associated with ssp. vaseyana canopy recovery rate $(\mathrm{P}>0.40)$. 

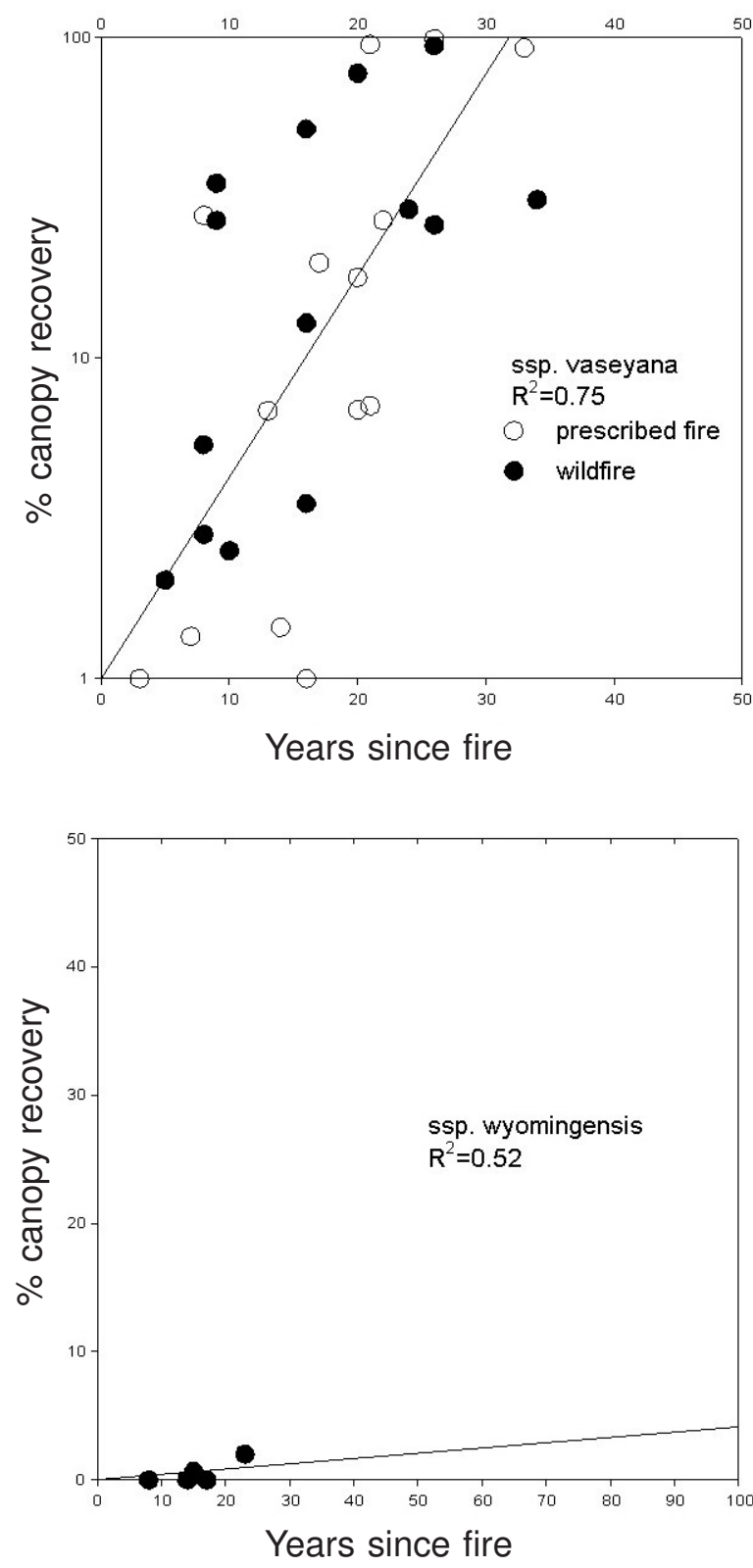

Figure 2. Log-linear relationship between canopy cover of Artemisia tridentata ssp. vaseyana and time since fire for 28 prescribed fires and wildfires (above) and linear relationship between ssp. wyomingensis and time since fire $(N=6$, below). Regression models were constrained to pass through the origin.

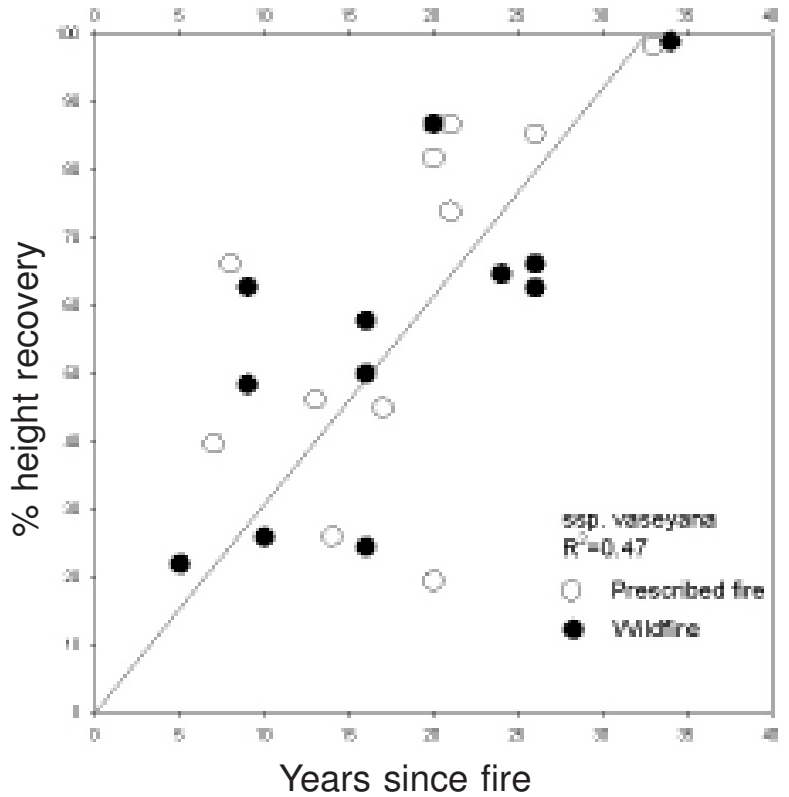

Figure 3. Relationship between canopy height of Artemisia tridentata ssp. vaseyana and time since fire for 23 prescribed fires and wildfires. Regression model was constrained to pass through the origin.

A regression model with head load, increasing sand in the soil and mean annual site precipitation explained $51 \%$ of the variation in rate of sagebrush canopy recovery across all subspecies. However, this relationship was driven by differences among subspecies; ssp. wyomingensis had low recovery rates and occurs in more arid environments and ssp. tridentata, with high recovery rates, is found on sandy soils. Soil texture and precipitation were not related to ssp. vaseyana recovery rate taken alone $(\mathrm{P}>0.34)$. There was also no relationship between sagebrush canopy recovery rate and heat load across all subspecies $(\mathrm{P}>0.54)$.

\section{Three-tip Sagebrush}

We found no evidence that Artemisia tripartita usually increased following fire. Artemisia tripartita was present at nine sites, six dominated by ssp. vaseyana, two by ssp. wyomingensis and one by ssp. tridentata. Mean canopy cover of $A$. tripartita was $6 \pm 3 \%$ in burned plots and $3 \pm 1 \%$ in unburned control plots $(\mathrm{t}=0.93, \mathrm{P}=0.37)$.

Artemisia tripartita density increased greatly at one site but declined at five sites following fire. As a result, mean $A$. tripartita density did not differ 
between burned plots $\left(0.8 \pm 0.4\right.$ plants $\left./ \mathrm{m}^{2}\right)$ and unburned controls $\left(0.7 \pm 0.3\right.$ plants $/ \mathrm{m}^{2} ; \mathrm{t}=0.20, \mathrm{P}=$ 0.85). Mean height of the dominant size class of $A$. tripartita plants did not differ between burned plots $(46 \pm 14 \mathrm{~cm})$ and controls $(43 \pm 8 ; \mathrm{t}=0.45, \mathrm{P}=0.67)$. Of the 55 A. tripartita plants in burned macroplots for which an accurate age was determined, only six (12\%) had survived fire. The majority of $A$. tripartita plants in burned macroplots were the age of the burn $( \pm 1 \mathrm{yr})$ in four of nine stands. Mean survival of $A$. tripartita was $15 \pm 3 \%$ in the Winslow Fire.

\section{Sagebrush Recruitment}

Minimum age of stands represented by unburned control macroplots ranged from 27 to 66 years. The number of cohorts present in these latesuccessional stands ranged from 1 to 8 with a mean of 5 . The number of cohorts in burned macroplots was strongly associated with time since fire $(\mathrm{N}=$ $38, \mathrm{R}^{2}=0.58, \mathrm{P}<0.001$; Fig. 4). When the regression line was constrained to go through the origin, the best-fit linear model had a slope of 0.12 , indicating one cohort every eight years following the fire. After correcting for age, there was no difference in age-class distribution $\left(\mathrm{F}_{2,34}=0.2, \mathrm{P}=\right.$ $0.80)$ or number of cohorts $\left(F_{2,34}=0.5, P=0.63\right)$ among subspecies in control plots. There was often a pulse of recruitment in burned macroplots immediately following fire for A. tripartita and $A$. tridentata ssp. vaseyana, but this pattern was not discernable for $A$. tridentata ssp. tridentata and ssp. wyomingensis (Fig. 5), although sample sizes for these taxa were smaller (Fig. 5). There was no difference in age-class distribution $\left(\mathrm{F}_{2,32}=1.1, \mathrm{P}=\right.$ $0.34)$ or number of cohorts $\left(F_{2,34}=1.8, P=0.19\right)$ among subspecies in burned plots after correcting for time since fire. There was no difference between prescribed fire and wildfire macroplots in age-class distribution $\left(\mathrm{F}_{1,33}=1.4, \mathrm{P}=0.24\right)$ or number of cohorts $\left(\mathrm{F}_{1,35}=0.2, \mathrm{P}=0.68\right)$ after correcting for time since fire. Regression analysis indicated that recruitment of Artemisia tridentata was not strongly associated with precipitation across the study area in either burned or unburned plots $(\mathrm{P}>0.16)$. However, age-class distribution in burned macroplots was positively associated with mean annual precipitation $\left(\mathrm{N}=36, \mathrm{R}^{2}=0.46, \mathrm{P}=\right.$
0.012 ) and tended to be positively associated in unburned controls $\left(\mathrm{N}=38, \mathrm{R}^{2}=0.18, \mathrm{P}=0.098\right)$.

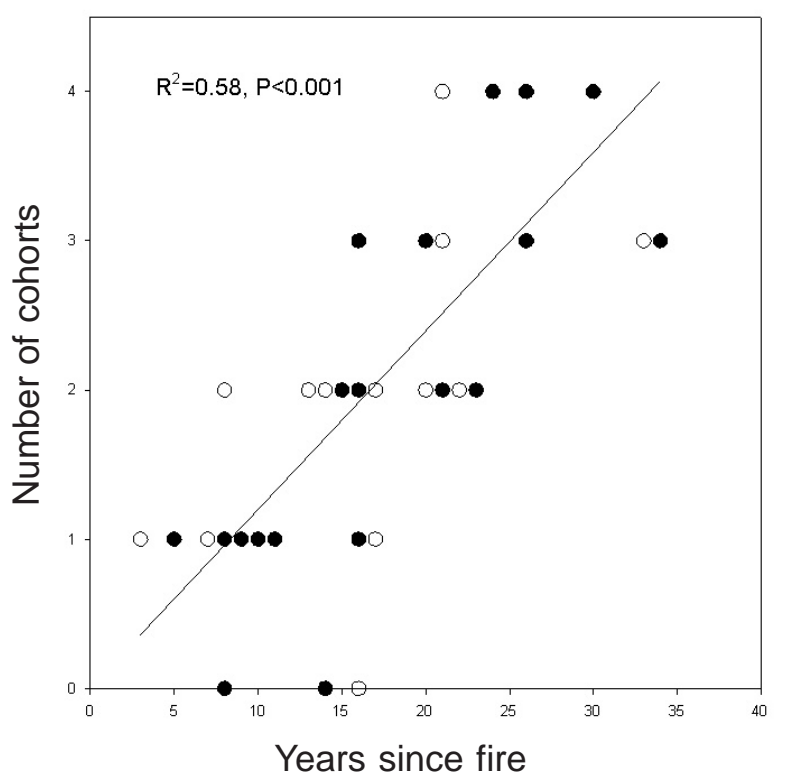

Figure 4. Relationship between the number of sagebrush cohorts (even-age 2 yrs groups) and time since fire for 38 prescribed fires and wildfires among three subspecies of A. tridentata. Regression model was constrained to pass through the origin.

\section{Subdominant Shrubs}

We found little evidence for consistent changes in the abundance of other common rangeland shrubs following fire. Canopy cover of shrubs other than Artemisia spp. was too low for detection in most macroplots, so we used density to assess the effects of fire on these species. Mean density of Chrysothamnus nauseosus for sites where it was recorded $(\mathrm{N}=13)$ was $0.13 \pm 0.06$ plants $/ \mathrm{m}^{2}$ and $0.10 \pm 0.03$ plants $/ \mathrm{m}^{2}$ for burned and unburned control macroplots respectively $(\mathrm{t}=0.57, \mathrm{P}=0.57)$. Mean density of $C$. viscidiflorus for sites where it was recorded $(\mathrm{N}=24)$ was $50 \%$ greater in burned macroplots $\left(0.37 \pm 0.12\right.$ plants $\left./ \mathrm{m}^{2}\right)$ than unburned controls $\left(0.24 \pm 0.09\right.$ plants $\left./ \mathrm{m}^{2}\right)$, although this difference was not significant $(\mathrm{t}=1.49, \mathrm{P}=0.15)$. At three sites there was a large increase $(\geq 0.5$ plants $/ \mathrm{m}^{2}$ ) in C. viscidiflorus density in the burned macroplot. Mean density of Tetradymia canescens for sites where it was recorded $(\mathrm{N}=$ 16) was $150 \%$ greater in burned macroplots 


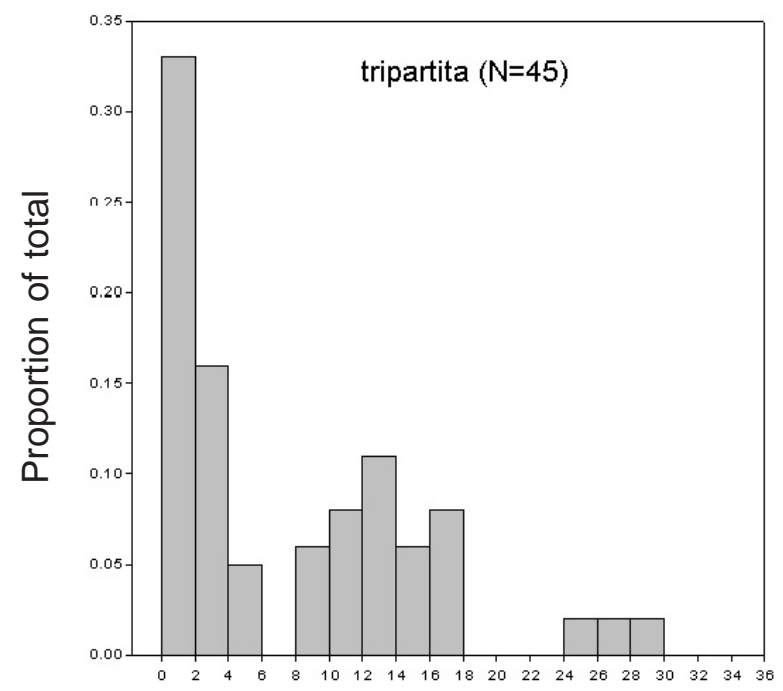

Years after fire

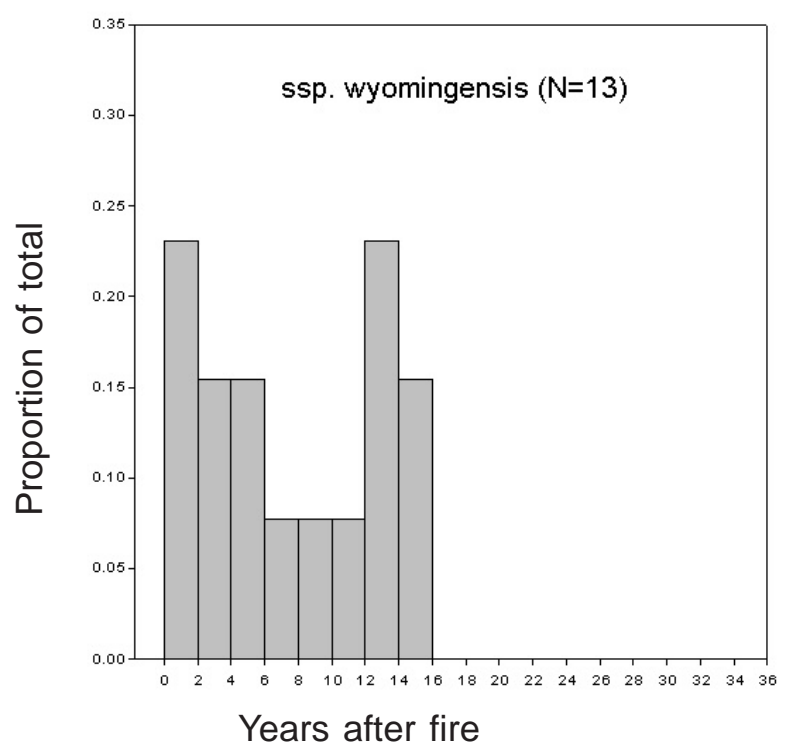

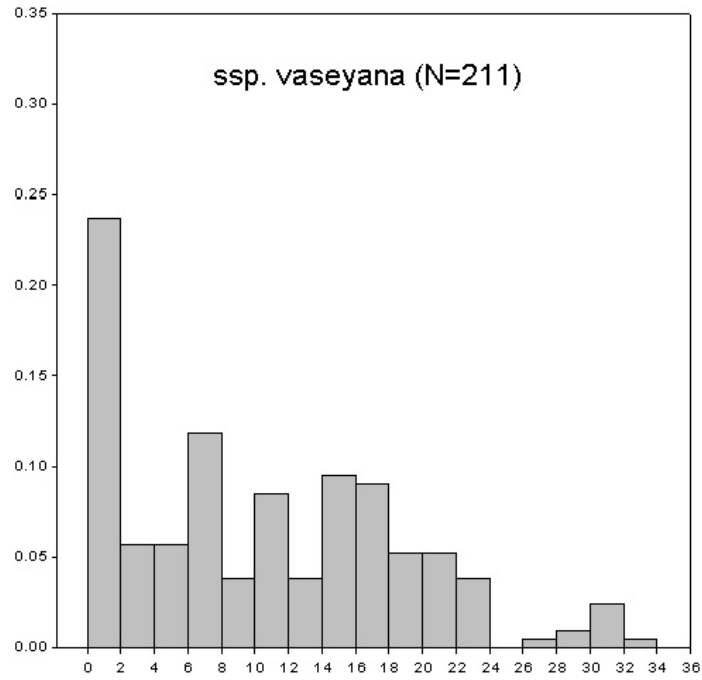

Years after fire

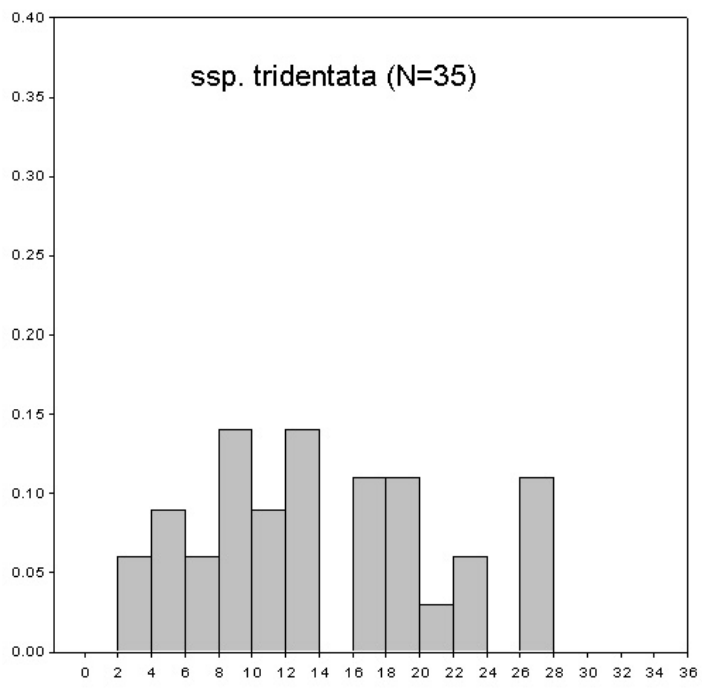

Years after fire

Figure 5. Frequency distribution for recruitment of sagebrush plants in years following fire for four taxa. Only accurate age measurements were used. Plants that survived the fire are not shown.

$\left(0.28 \pm 0.16\right.$ plants $\left./ \mathrm{m}^{2}\right)$ than unburned controls $\left(0.11 \pm 0.04\right.$ plants $\left./ \mathrm{m}^{2}\right)$, but this difference was also not significant $(\mathrm{t}=1.5, \mathrm{P}=0.16)$. At three sites there was a large increase $\left(\geq 0.5\right.$ plants $\left./ \mathrm{m}^{2}\right)$ in $T$. canescens density in the burned macroplot. Mean density of all three subdominant shrubs together was nearly twice as great in burned macroplots $\left(0.46 \pm 0.12\right.$ plants $\left./ \mathrm{m}^{2}\right)$ as in controls $(0.24 \pm 0.07$ plants $\left./ \mathrm{m}^{2}\right)$ where they occurred $(\mathrm{N}=33, \mathrm{t}=2.1, \mathrm{P}$ $=0.042$ ).

\section{Graminoids}

The most frequent perennial graminoids across all study sites were Festuca idahoensis, Agropyron spicatum and Carex filifolia. Total perennial graminoid canopy cover was similar for burned 
macroplots and unburned controls in stands dominated by Artemisia tridentata ssp. wyomingensis $(\mathrm{t}=0.54, \mathrm{P}=0.61)$ and by $A$. $t$. ssp. tridentata $(\mathrm{t}=0.06, \mathrm{P}=0.96$; Fig. 6$)$. Perennial graminoid cover was greater in burned than unburned control macroplots in stands dominated by A. tridentata ssp. vaseyana $(\mathrm{t}=2.6, \mathrm{P}=0.014$; Fig. 6). This difference was driven by changes in Agropyron spicatum rather than Festuca idahoensis. There was no evidence for a difference in F. idahoensis between burned macroplots and unburned controls across all subspecies where it occurred $(\mathrm{N}=33, \mathrm{t}=0.8$, $\mathrm{P}=0.44$ ), but mean cover of $A$. spicatum was $11 \pm 2 \%$ in burned macroplots plots compared to $7 \pm 1 \%$ in controls $(\mathrm{N}=32, \mathrm{t}=2.7, \mathrm{P}=0.012)$. There was no difference in canopy cover of Carex filifolia between burned and unburned control macroplots where it occurred $(\mathrm{N}=10, \mathrm{t}=0.87, \mathrm{P}=$ 0.41). Fire-induced proportional change in grass cover in ssp. vaseyana stands was not associated with mean annual precipitation, heat load or soil texture after correcting for time since fire $(\mathrm{P}>$ 0.34). Total canopy cover of perennial grasses, as well as cover of Festuca idahoensis or Agropyron spicatum in unburned control macroplots (a surrogate of grazing intensity) was not associated

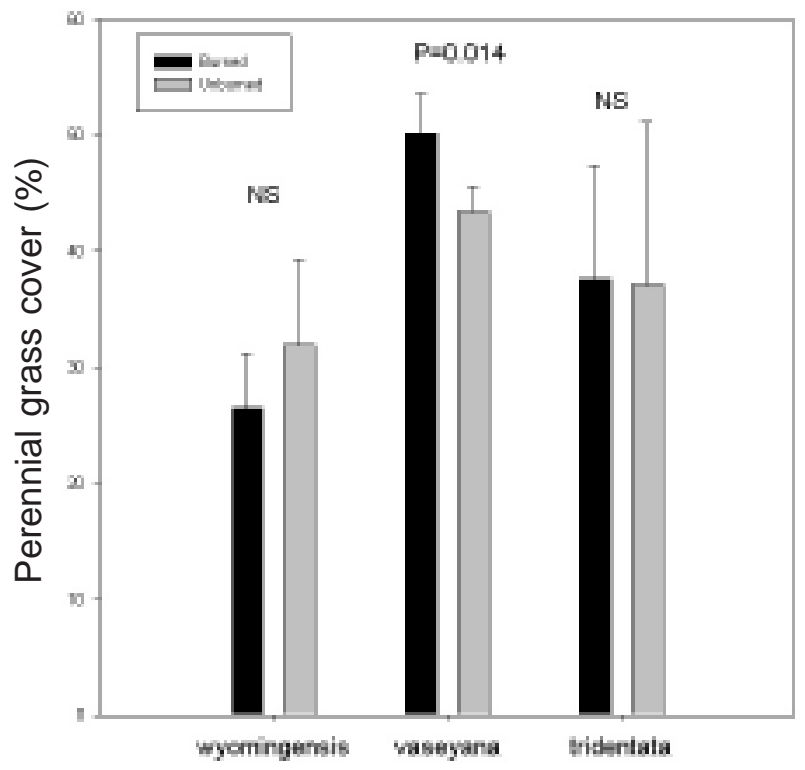

Figure 6. Mean perennial graminoid canopy cover (SE) in burned and unburned control macroplots for three subspecies of Artemisia tridentata. Statistical significance determined by paired-sample t-test. with fire-induced proportional change in grass cover $(P>0.52)$.

The increase in perennial grass canopy cover was most pronounced soon after fire and declined with time since fire (Fig. 7). On average grass cover in burned $A$. tridentata ssp. vaseyana macroplots returned to control levels within about 30 years after fire (Fig. 7). Perennial grass cover averaged $13 \%$ higher in burned macroplots following prescribed fire but only $4 \%$ higher following wildfire, and this difference was significant after correcting for time-since-fire differences $\left(\mathrm{F}_{1,25}=\right.$ 7.6, $\mathrm{P}=0.028)$.

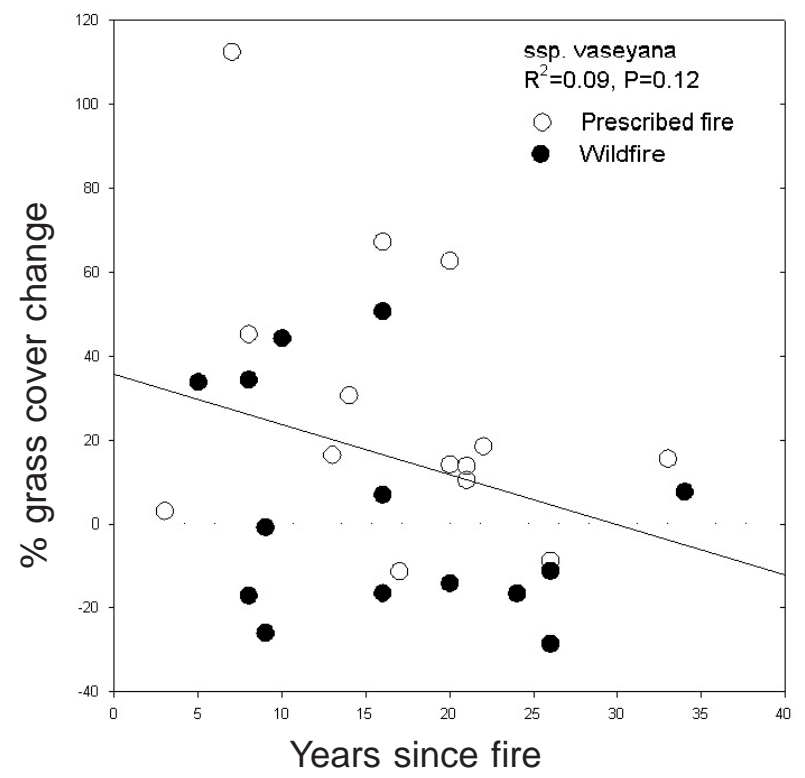

Figure 7. Relationship between percent perennial graminoid canopy cover change (burned macroplotcontrol macroplot) and time since fire for Artemisia tridentata ssp. vaseyana. Note that most prescribed fires occur above the zero-change line, while the majority of wildfires are below the line.

\section{Forbs}

Fire-induced changes in the canopy cover of forbs were small, but there was a significant difference in response among the three subspecies $\left(\mathrm{F}_{2,34}=4.6, \mathrm{P}\right.$ $=0.017$ ). The proportional decline in forb cover in ssp. tridentata stands was different than the responses in stands dominated by either ssp. wyomingensis or ssp. vaseyana $\left(\mathrm{F}_{1,34}>8.6, \mathrm{P}<\right.$ 
0.006), but there was no difference between these latter two subspecies $\left(\mathrm{F}_{1,34}=0.2, \mathrm{P}=0.68\right)$. Forb cover was $7 \pm 1 \%$ and $8 \pm 1 \%$ for burned macroplots and unburned controls respectively at sites dominated by A. tridentata ssp. wyomingensis $(\mathrm{t}=0.99, \mathrm{P}=0.37)$. At sites dominated by ssp. tridentata, mean forb cover was $1 \pm 0.5 \%$ and $6 \pm 4 \%$ for burned macroplots and unburned controls respectively $(\mathrm{t}=1.15, \mathrm{P}=0.33)$. At ssp. vaseyana sites there was a marginally significant tendency ( $\mathrm{t}=1.94, \mathrm{P}=0.06$ ) for forb cover to be higher in burned macroplots ( $25 \pm 3 \%$ ) compared to controls ( $22 \pm 2 \%)$, but there was no evidence for an association with time since fire $\left(\mathrm{R}^{2}<0.01, \mathrm{P}=\right.$ 0.97). The proportional change in forb cover following fire at sites dominated by $A$. tridentata ssp. vaseyana did not differ between prescribed fires and wildfires after accounting for time-sincefire differences $\left(\mathrm{F}_{1,25}=0.2, \mathrm{P}=0.71\right)$.

There was no evidence for a change in the abundance of forbs in the Cichorieae Tribe of the Asteraceae. The most common native Cichorieae were Agoseris glauca and Nothocalais troximoides, while the common exotics were Taraxacum officinale/laevigatum and Tragopogon dubius. Mean density of native members of the Cichorieae was $0.9 \pm 0.3$ plants $/ \mathrm{m}^{2}$ for burned macroplots and $1.1 \pm 0.3$ plants $/ \mathrm{m}^{2}$ for unburned controls in which they were present, and this difference was not significant $(\mathrm{N}=25, \mathrm{t}=0.59$, $\mathrm{P}=0.56$ ). Mean density of exotic Cichorieae plants was $2.7 \pm 0.9$ plants $/ \mathrm{m}^{2}$ for burned and 2.0 \pm 0.6 plants $/ \mathrm{m}^{2}$ for unburned controls in which they were present, and this difference was not significant $(\mathrm{t}=1.56, \mathrm{P}=0.13)$. Season of burn (prescribed vs. wildfire) did not affect the change in density of either native $\left(\mathrm{F}_{1,23}=2.4, \mathrm{P}=0.14\right)$ or exotic $\left(\mathrm{F}_{1,28}=0.73, \mathrm{P}=0.40\right)$ Cichorieae forbs between burned macroplots and controls, and there was no difference among stands dominated by different subspecies of $A$. tridentata $\left(\mathrm{F}_{2,28}=0.02\right.$, $\mathrm{P}=0.98)$.

\section{Species Richness}

Species richness in unburned control macroplots differed among the three subspecies of $A$.

tridentata $\left(\mathrm{F}_{2,35}=6.7, \mathrm{P}=0.003\right)$. Species richness was lower for ssp. tridentata controls $(17 \pm 3)$ than either ssp. wyomingensis (27 \pm 3 ) or ssp. vaseyana $(30 \pm 1)\left(F_{1,35}>5.1, \leq 0.03\right)$, but did not differ between the latter two subspecies $\left(\mathrm{F}_{1,35}=1.2, \mathrm{P}=\right.$ 0.30 ). The proportional change in species richness between burned macroplots and unburned controls did not differ among species $\left(\mathrm{F}_{2,35}=1.5, \mathrm{P}=0.23\right)$, and there was no difference in species richness between burned and control macroplots $(\mathrm{t}=1.07$, P $=0.29$ ). Mean species richness declined by $7 \pm 4 \%$ following wildfire but increased by $4 \pm 9 \%$ following prescribed fire, but this difference was not significant $\left(\mathrm{F}_{1,36}=2.5, \mathrm{P}=0.12\right)$.

\section{Soil Organic Matter}

Soil organic matter varied between $1.7 \%$ and $13.8 \%$ and averaged $0.7 \%$ lower in burned compared to unburned control plots; however, this difference was only marginally significant $(\mathrm{t}=1.8$, $P=0.08)$, and percent organic matter increased post-fire in many stands (Fig. 8). The change in organic matter following fire was not related to the length of time since fire $(\mathrm{P}=0.89)$ and did not differ among the subspecies of $A$. tridentata $\left(\mathrm{F}_{1,36}\right.$ $=0.16, \mathrm{P}=0.70)$ nor between prescribed fire and wildfire $\left(\mathrm{F}_{1,36}=0.16, \mathrm{P}=0.70\right)$. Post-fire change in organic matter was not associated with mean annual precipitation, heat load or soil texture $(\mathrm{P}>$ $0.95)$. 


\section{Discussion}

\section{Post-fire Recovery}

Sagebrush

We observed near complete mortality of Artemisia tridentata in recently burned stands. The speed with which Artemisia tridentata recolonized a burned site depended on subspecies. Mean rate of canopy recovery was highest for ssp. tridentata and lowest for ssp. wyomingensis. Recovery of ssp. vaseyana canopy was logarithmic, and a loglinear model based on 28 sample pairs predicts that $100 \%$ recovery of this subspecies will occur after 32 years on average (Fig. 2). Our model for ssp. wyomingensis recovery was based on only six sample pairs; nonetheless, it is clear that this subspecies recovers much more slowly because we observed less than $2 \%$ recovery after as many as 23 years in these six stands. Full canopy recovery of ssp. tridentata was reached within 26 years after fire in two of four sites studied. Recovery of sagebrush canopy height was similar for the three subspecies, and a linear model suggests that full recovery will be achieved on average after 33 years (Fig. 3).

Variation in the rate of sagebrush canopy recovery among subspecies could be due to differences in recruitment and/or growth. In a controlled greenhouse study, seedling growth rate was lowest for ssp. wyomingensis, and highest for ssp. tridentata (Booth et al. 1990), and this same pattern held for juvenile plants in a common garden (McArthur and Welch 1982). There is little information on the ability of different subspecies of A. tridentata to recruit in the field (see below). Ssp. wyomingensis occupies the driest sites with the most poorly developed soil (Morris et al. 1976, Barker and McKell 1983) and so might be expected to have the most difficulty recolonizing.

We were unable to identify any biotic or abiotic factors associated with recovery rates of spp. vaseyana canopy cover across our study area. We hypothesized that stands on cool slopes or in areas of higher precipitation would recover faster (Johnson and Payne 1967) and that stands on finetextured soils would recover more slowly (Gruell 1980). However, there was no association between the rate of ssp. vaseyana canopy recovery and mean annual precipitation, heat load or soil texture, and a model with all three abiotic variables explained less than $1 \%$ of the variation in recovery rate.

It is generally believed that proximity to a seed source promotes faster recovery (Blaisdell 1953, Gruell 1980) because the seed bank of $A$. tridentata is small or non-existent (Young and Evans 1989, Akinsoji 1988). In our study, prescribed burns, for which there were often some surviving plants to act as a seed source, did not recover faster than the more severe wildfires. In fact, there was a non-significant tendency ( $\mathrm{P}=$ 0.12 ) for ssp. vaseyana to recover faster following wildfire than prescribed fire. Wambolt and Payne (1986) also found no re-establishment of ssp. wyomingensis six years after a prescribed fire in spite of the close proximity of a seed source.

We found no support for a relationship between grazing regime and sagebrush canopy recovery rate. All of our ssp. vaseyana stands were in the same habitat type (Mueggler and Stewart 1980) and have similar plant associations (Cooper et al. 1999). Perennial grasses, especially Festuca idahoensis and Agropyron spicatum, decrease with overgrazing by cattle in this habitat type (Mueggler and Stewart 1980), so canopy cover of palatable grasses in unburned control plots should be a long-term index of grazing intensity. We found no relationship between cover of perennial grasses in control plots and sagebrush canopy recovery rate following fire, suggesting that post-fire grazing does not have a large effect on recovery. Unfortunately, we had no way of assessing immediate post-fire grazing for many of the older burns and what effects this variable may have had on sagebrush recovery.

Other studies have reported recovery times similar to ours. After 15 years, post-burn stands of ssp. vaseyana in southeast Idaho were only ca. 25\% recovered (Pechanec et al. 1954); however, after 30 years they had returned to preburn canopy cover (Harniss and Murray 1973). In another southeast 
Idaho study Humphrey (1984) found that a stands of ssp. vaseyana recovered after 20 years. After 18 years canopy cover of ssp. wyomingensis was only $12 \%$ of preburn levels following a prescribed fire (Wambolt and Payne 1986). In the Missouri River Breaks of central Montana wildfire eliminated spp. wyomingensis from upland sites and it has yet to reestablish in the succeeding 14 years (Eichorn and Watts 1984). However, others have reported conflicting results. Average recovery of ssp. vaseyana canopy following wildfire in south-central Montana was little more than 1\% after 11-17 years (Hoffman 1996), and Wambolt et al. (2001) observed less than 15\% recovery in seven of eight ssp. vaseyana stands after up to 16 years following prescribed fire. In ssp. wyomingensis stands Wambolt et al. (2001) found $72 \%$ recovery after 32 years and $96 \%$ recovery after only nine years; however it is important to make the distinction that they studied cool-season, prescribed fires whereas five of our six samples documented wildfires.

Our results can be used to describe the presettlement occurrence of $A$. tridentata ssp. vaseyana on the southwest Montana landscape. Mean presettlement fire interval in these communities was estimated to be 25 years based on fire scarred trees at the sagebrush-forest ecotone (Arno and Gruell 1986). The majority of ssp. vaseyana stands would have been in early to midseral condition if we assume a mean fire interval of 25 years and a mean full recovery time of 32 years. More precise estimates of the presettlement sagebrush mosaic composition are not possible because results of our study surely depend on climate, and climate during the time encompassed by our study (ca. past 30 years) may have been different than presettlement climate.

\section{$\underline{\text { Subdominant Shrubs }}$}

We expected to observe a fire-induced increase in the subdominant shrubs, Chrysothamnus nauseosus, C. viscidiflorus and Tetradymia canescens. All three species resprout after being burned (Young and Evans 1978), and all are reported to increase following fire (Mueggler and Blaisdell 1958, Wright et al. 1979). Indeed, we did record large increases following fire in a few stands for each of these species. However, large increases in individual species were the exception, and we found no significant differences between burned and control macroplots for any of these three species taken alone. However, we did observe a significant increase in burned macroplots if we consider these shrubs as a single guild. This subdominant shrub guild is expected to increase with fire frequency, especially becuse there was little evidence for a decline in the fire effect with time since fire.

We also expected to observe an increase in Artemisia tripartita associated with fire because it too is capable of resprouting following fire (Morris et al. 1976, Beetle and Johnson 1982). Passey and Hugie (1962) report pure stands of A. tripartita that they believe were the result of fire. Morris et al. (1976) provide anecdotal evidence that frequent fire favors A. tripartita over A. tridentata ssp. vaseyana. At the Badger South site we did observe a dramatic replacement of ssp. vaseyana by A. tripartita following fire and at the Centennial Sandhills site, potentially dominated by spp.

tridentata, A. tripartita constituted $72 \%$ of a total $35 \%$ sagebrush cover on the burned site (and only $1 \%$ of $25 \%$ total cover on the control). However, A. tripartita density and canopy cover decreased following fire at the majority of the our study sites where it was present, and only a small proportion of plants survived the Winslow Fire in the Centennial Valley. It is notable that $A$. tripartita was recorded only once, a trace amount, in any of the stands potentially "climax" in ssp. wyomingensis; this observation may indicate that these sites are too xeric for this species.

\section{Graminoids}

Changes in graminoid cover following fire were moderate at best; only the average increase of $7 \%$ in burned ssp. vaseyana macroplots was statistically significant. Fire-induced increases were small in spite of the near complete mortality of the sagebrush canopy in most cases. Positive effects may have been negated by livestock grazing following fire when the grass became more accessible after shrub canopy removal (Pechanec et al. 1954, Harniss and Murray 1973, Bunting et al. 1998); however we found no evidence to support 
this effect. Perennial grass cover in unburned control plots, an index of long-term grazing intensity (see above) was not associated with proportional changes in grass cover following fire, suggesting that post-fire grazing does not have a large effect on fire-induced changes. We had no way of assessing immediate post-fire grazing for many of the older burns and what effects it may have had on grass cover. On average the positive effect of fire on perennial graminiod cover in our study sites was no longer apparent after 30 years, about the same length of time required for full sagebrush canopy closure (Fig. 7).

Previous studies in sagebrush steppe suggest that changes in perennial graminoid productivity depend on time since fire. There was no increase in overall grass production three years after prescribed fire in southeast Idaho (Mueggler and Blaisdell 1958), but grass productivity increased for the next nine years and then declined (Pechanec et al. 1954, Harniss and Murray 1973). Singer and Harter (1996) found that wildfire increased grass production four-fold two years after fire in ssp. vaseyana stands in Yellowstone National Park. Changes in canopy cover of perennial grass following prescribed fire in southwest Montana varied among sites but were not significantly different across all sites (Fraas et al. 1992, Wambolt et al. 2001). However, Hoffman (1996) found that perennial grass cover averaged $47 \%$ higher in plots burned by wildfire compared to adjacent unburned plots in ssp. vaseyana stands in south-central Montana. On average the positive effect of fire on perennial graminoid cover in our study sites was no longer apparent after ca. 25 years, about a decade before full recovery of the sagebrush canopy (Fig. 7).

Festuca idahoensis is reported to be damaged by fire because of its densely caespitose growth form (Wright et al 1979); however, we observed no difference in F. idahoensis cover between burned and control macroplots. It may be that fire damage was mitigated by nutrient release and increased light (Hulbert 1988, Dudley \& Lajtha 1993). The positive response of Agropyron spicatum was the main driver of increased grass cover in ssp. vaseyana burned macroplots. Foliage of this species is not concentrated at the base of the plant to the same extent as F. idahoensis, so fire may be less damaging.

Other researchers have generally reported fire responses similar to ours; Festuca idahoensis is damaged by fire while Agropyron spicatum is not (Wright et al. 1979). However, these results appear to be more typical of wildfire than prescribed fire. Wildfires in west-central Montana and northeast Oregon caused a decline in basal cover of $F$. idahoensis but not A. spicatum (Conrad and Poulton 1966, Antos et al. 1983). Humphrey (1984) found that $A$. spicatum cover increased after wildfire in southeast Idaho but in Utah on a ssp. wyomingensis site a distinct decrease in cover of this grass following wildfire was noted and two years post-burn its cover still lagged considerably that of the controls (West and Hassan 1985).

Both grass species generally respond positively to prescribed fire. Agropyron spicatum production was lower three years after prescribed fire on a ssp. vaseyana site in east Idaho (Mueggler and Blaisdell 1958); however, production increased for the next nine years and then declined (Blaisdell 1953, Harniss and Murray 1973). Three years after prescribed fire production of $A$. spicatum had increased on ssp. vaseyana sites in south-central Wyoming (Cook et al. 1994), and production of $A$. spicatum was greater four years after prescribed fire increased on ssp. wyomingensis sites in southwest Montana (Wambolt and Payne 1986). In ssp. wyomingensis stands following prescribed fire Peek et al. (1979) reported no change in the production of A. spicatum following prescribed fire in eastern Idaho, and in south-central Idaho, Clifton (1981) found no significant change in A. spicatum cover one and two years postfire and 100 percent of tagged specimens also survived over this period. Festuca idahoensis production increased following prescribed fire at several sites in southwest Montana but not at others (Wambolt et al 2001). On the other hand, F. idahoensis production declined immediately after prescribed fire and then gradually recovered in an east Idaho ssp. vaseyana stand (Blaisdell 1953, Harniss and Murray 1973). Contrary to nearly all field studies, Robberecht and DeFosse (1995), in a garden experiment, found that 
F. idahoensis was less damaged by fire than $A$. spicatum.

\section{Forbs}

Forbs, especially those in the Cichorieae Tribe of the Asteraceae are an important component of sage grouse diet during the summer and are often critical for successful brood rearing (Klebenow and Gray 1967, Peterson 1970, Barnett and Crawford 1994, Drut et al. 1994). Forbs are expected to increase with the temporary, fire-induced reduction in shrub and grass canopy (Klebenow 1973, Glenn-Lewin et al. 1990, Leach and Givnish 1996). However, our results suggest that fire will have a small positive effect on forb canopy cover only in ssp. vaseyana stands, possibly because these stands have the greatest shrub canopy cover and the understories experience the greatest proportional release from competition following fire. Although exotic members of the Cichorieae were much more abundant following fire at several sites, we found no evidence for a consistent fire-induced change in either native or exotic members of this group of forbs. This seems surprising since exotic Cichorieae are invasive and expected to increase with disturbance (Hobbs and Huenneke 1992, Kotanen et al 1998). Species richness, which is mainly a reflection of the number of forbs, was not affected by fire.

Our results suggest that the forb component of these fire-prone steppe communities are adapted to fire and change little during the course of secondary succession. Other researchers have reported similar results for sagebrush steppe. Frequency of forbs was not affected by prescribed fire three years after the burn (Peek et al. 1979), and forb production remained stable for 30 years following prescribed fire in eastern Idaho (Harniss and Murray 1973). However, Mueggler and Blaisdell (1958) reported that forb production was higher three years after prescribed fire in the same area. Wildfire did not alter forb production in Yellowstone National Park (Singer and Harter 1996), and frequency of forbs was not affected by prescribed fire three years later in south-central Wyoming (Cook et al. 1994). Neither Hoffman (1996) nor Fraas et al (1992) observed any change in canopy cover of forbs following wildfires in south-central or southwest Montana. Flowering of forbs increased but abundance was unchanged one year after prescribed fire in eastern Oregon (Wrobleski and Kauffman 2003).

The small, marginally significant loss of soil organic matter was most likely from the surface horizons due to volatilization and/or erosion. The cooler prescribed fires would be expected to have less of an effect, but we found no evidence for smaller organic matter losses in prescribed burns compared to wildfires in our study. The fact that loss of organic matter did not decline with time since fire suggests that in some instances it may take many decades for soil organic matter to return to preburn levels after it has been lost (Fig. 8).

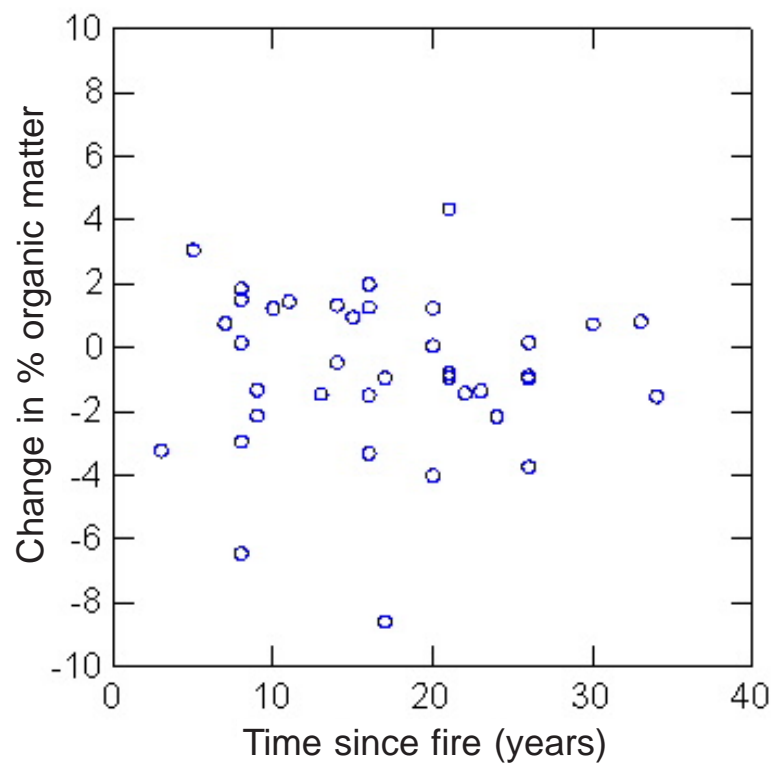

Figure 8. Change in soil organic matter percentage for control - burned plot pairs.

\section{Sagebrush Recruitment}

Recruitment of Artemisia tripartita and A. tridentata ssp. vaseyana frequently occurred directly following fire, but this post-fire recruitment pulse was not observed for ssp. wyomingensis or ssp. tridentata (Fig. 5). Both of the former taxa were most common in stands dominated by ssp. vaseyana, which are virtually always more mesic than stands dominated by ssp. wyomingensis (Morris et al. 1976, Winward 2004) and usually more mesic than stands characterized by ssp. 
tridentata (Barker and McKell 1983, Winward 2004), although a complex relationship exists with subsurface moisture. Immediate regeneration is expected to be more likely at sites where adequate moisture is more reliable. Prompt recruitment of ssp. vaseyana compared to ssp. wyomingensis partially explains the relatively fast post-fire recovery of ssp. vaseyana canopy. The quick recovery of ssp. tridentata canopy is apparently not due to rapid recruitment, but more likely can be attributed to fast growth; both seedling and juvenile plants of ssp. tridentata grow faster than either of the other subspecies (McArthur and Welch 1982, Booth et al. 1990).

Nearly all unburned control sagebrush macroplots were uneven-aged, indicating that recruitment was not limited to immediate post-fire conditions in any of the subspecies. On average, recruitment occurred every eight years, and an average of five cohorts were present in late-seral stands. Similar results have been obtained for south-central Montana (Hoffman 1996) and eastern Idaho where ssp. vaseyana stands support plants of many ages with small pulses of recruitment occurring at moreor-less regular intervals (West et al. 1979, Perryman et al. 2001). Although years of exceptionally high recruitment related to climate may occur (Daubenmire 1975), it appears that most recruitment following the immediate post-burn years is more constant and not related to precipitation (West et al. 1979). These results indicate that $A$. tridentata is a true "climax" species, able to reproduce where it is the dominant plant.

It is usually assumed that Artemisia tripartita increases following fire because it is capable of resprouting, while $A$. tridentata is killed (Daubenmire 1970, Morris et al. 1976, Beetle and Johnson 1982). However, only $15 \%$ of $A$. tripartita plants resprouted after the Winslow fire, and most plants in burned macroplots were younger than the age of the burn, suggesting that post-fire recruitment is primarily from seed rather than by resprouting. On average $50 \%$ of $A$. tripartita plants in burned macroplots were recruited within the four years immediately following the fire (Fig.
5), suggesting that frequent fire is likely to favor its dominance (Passey and Hugie 1962).

\section{Prescribed Fire and Wildfire}

Season of burn is often a significant factor in determining the effects of fire in grasslands and shrublands (Howe 1994). Prescribed fires are usually conducted during early spring and late fall in north temperate regions to minimize the chance of losing control. These are times when many native species are dormant, temperatures are cooler, humidity is higher, and fuels are often moister. Wildfires usually occur during the growing season with high temperatures and low humidity. Several studies have found that prescribed fires affect plant communities differently than wildfire (Biondini et al. 1989; Howe 1995, Lesica 1999). Our study could not directly test for differences between prescribed fire and wildfire because we did not have both treatments at the same site. Nonetheless, our study design should have allowed us to detect any large differences between these two types of fire. There was little difference in the rate of sagebrush canopy cover or height recovery between prescribed fire and wildfire. The weak trend for quicker canopy recovery following wildfire $(\mathrm{P}=0.12)$ may indicate that warm-season fires create a better seed bed for winter-dispersed sagebrush seed. The positive effect of fire on perennial grass cover at ssp. vaseyana sites was much greater following prescribed fire than wildfire (see above). The less severe prescribed fires probably do less damage to bunchgrasses than wildfire because there is less chance of burning into the plant crowns. Other studies in sagebrush steppe suggest this same relationship (see above). There was no difference in the response of forbs between prescribed fire and wildfire; however, species richness increased following prescribed fire but declined after wildfire although the difference between them was not significant $(\mathrm{P}=0.12)$.

\section{Implications for Management}

The rate of sagebrush canopy recovery did vary among the three subspecies of Artemisia tridentata. Our model indicates that stands of ssp. vaseyana, the most common sagebrush in southwest Montana, will recover from fire, on 
average, in 32 years. Based on our data, it is clear that ssp. wyomingensis takes much longer to recover. Prescribed fire in spp. wyomingensis stands will likely result in the loss of the sagebrush resource for as much as 100 years or more, though literature sources (see above) suggest that response for this subspecies can be highly variable. Stands of ssp. tridentata will usually recover quickly, perhaps in little more than 20 years. However, these stands have become much less common due to agriculture and human development (Lesica and Cooper 1997). Further loss to management activity could adversely affect animals dependent on tall sagebrush cover such as pygmy rabbits (Weiss and Verts 1984, Katzner and Parker 1997, Rauscher 1997). Proper identification of sagebrush subspecies is an important precursor to any management activity (Bunting et al. 1987, Winward 2004).

Managers cannot assume that stands of ssp. vaseyana on more mesic sites will recover faster or that sagebrush canopy will recover faster following prescribed fire compared to wildfire. We were unable to identify any abiotic factors associated with faster recovery of Artemisia tridentata ssp. vaseyana canopy across our study area. Soil texture, precipitation and slope aspect have been reported to influence sagebrush recovery (Johnson and Payne 1967, Gruell 1980); however, none of them were associated with the rate of canopy recovery in our study. We also failed to find an association between livestock grazing or distance to seed source and sagebrush canopy recovery rate, although our tests for these were indirect.

The results of our study have implications for protecting native biological diversity and managing livestock in sagebrush steppe in southwest Montana. Prescribed fire resulted in an average increase of $13 \%$ in grass canopy cover. Prescribed fire followed by light grazing may be a way of rejuvenating ssp. vaseyana stands. On average, the benefit will persist until the sagebrush canopy has recovered from the fire (ca. 32 years). This increased grass cover will be advantageous to sage grouse (Wallestad and Pyrah 1974, Aldridge and Brigham 2002). Wildfire, which does not reliably result in increased grass cover, is much less likely to provide these same benefits. Forbs, especially members of the Cichorieae, are important for sage grouse brood rearing. However, prescribed fire or wildfire will, on average, induce only a small increase (3\%) in the cover of forbs overall, and will have no effect on the abundance of plants in the Cichorieae in these sagebrush steppe systems.

Loss of the shrub canopy following fire increases availability of the herbaceous layer to grazers. While many wildfires reduced grass canopy cover, this was rarely the case for prescribed fire (Fig. 7). The average increase in forage production following prescribed fire was only $13 \%$, declining to pre-burn condition in about 30 years. Fire immediately followed by heavy grazing could ultimately reduce grass production by eliminating the protection offered by the shrub canopy, although we observed only two cases of reduced grass cover in a burned sample plot (Fig. 7).

Sage grouse require a mixture of open- and closedcanopy sagebrush habitats (Connelly et al. 2000). Stands of Artemisia tridentata ssp. vaseyana in southwest Montana require an average of 32 years to recover following fire. Thus, maintaining a mosaic of approximately half late-seral and half early-seral stands would require imposing a firereturn interval of about 50-80 years on all stands in the landscape. Artemisia tridentata ssp. tridentata appears to recover more quickly than ssp. vaseyana, so the proportion of mature stands of ssp. tridentata was probably higher in presettlement landscapes. Fire in these stands seems undesirable because so many have been lost to agriculture (Lesica and Cooper 1997). Only long fire-return intervals will allow stands dominated by ssp. wyomingensis to remain on the landscape in our study area. 


\section{Literature Cited}

Akinsoji, A. 1988. Postfire vegetation dynamics in a sagebrush steppe in southeastern Idaho, USA. Vegetatio 78: 151-155.

Aldridge, C. L. and R. M. Brigham. 2002. Sage grouse nesting and brood habitat use in southern Canada. Journal of Wildlife Management 66: 433444.

Anderson, J. E. and R. S. Inouye. 2001. Landscape-scale changes in plant species abundance and biodiversity of a sagebrush steppe over 45 years. Ecological Monographs 71: 531556.

Anderson, M., P. Bourgeron, M. T. Bryer, R. Crawford, L. Engelking, D. Faber-Langendoen, M. Gallyoun, K. Goodin, D. H. Grossman, S. Landaal, K. Metzler, K. D. Patterson, M. Pyne, M. Reid, L. Sneddon, and A. S. Weakley. 1998. International classification of ecological communities: terrestrial vegetation of the United States. Volume II. The National Vegetation Classification System: list of types. The Nature Conservancy, Arlington, VA, USA. 502 pp.

Antos, J. A., B. McCune and C. Bara. 1983. The effect of fire on an ungrazed western Montana grassland. The American Midland Naturalist 110: 354-364.

Arno, S. F. and G. E. Gruell. 1983. Fire history at the forest-grassland ecotone in southwestern Montana. Journal of Range Management 36: 332336.

Bailey, R. G. 1995. Descriptions of the ecoregions of the United States. Second Edition. U. S. Department of Agriculture, Forest Service. Misc. Publ. 1391.

Barker, J. R. and C. M. McKell. 1983. Habitat differences between basin and Wyoming big sagebrush in contiguous populations. Journal of Range Management 36: 450-454.
Barnett, J. K. and J. A. Crawford. 1994. Prelaying nutrition of sage grouse hens in Oregon. Journal of Range Management 47: 114-118.

Beetle, A. A. and K. L. Johnson. Sagebrush in Wyoming. University of Wyoming Agricultural Experiment Station Bulletin 779, Laramie.

Billings, W. D. 1949. The shadscale zone of Nevada and eastern California in relation to climate and soils. American Midland Naturalist 42: 87-109. Biondini, M. E., A. A. Steuter, and C. E. Grygiel. 1989. Seasonal fire effects on the diversity patterns, spatial distribution, and community structure of forbs in the Northern Mixed Prairie. Vegetatio 85: 21-31.

Blaisdell, J. P. 1953. Ecological effects of planned burning of sagebrush-grass range on the upper Snake River Plains. USDA Technical Bulletin 1975. Washington, DC.

Bock, C. E. and J. H. Bock. 1987. Avian habitat occupancy following fire in a Montana shrubsteppe. Prairie Naturalist 19: 153-158.

Booth, G. D., B. L. Welch, T. L. C. Jacobson. 1990. Seedling growth rate of 3 subspecies of big sagebrush. Journal of Range Management 43: 432436.

Bunting, S. C., B. M. Kilgore and C. L. Bushey. 1987. Guidelines for prescribed burning sagebrushgrass rangelands in the northern Great Basin. USDA Forest Service General Technical Report INT-231, Ogden, Utah.

Bunting, S. C., R. Robberecht and G. E. Defosse. 1998. Length and timing of grazing on postburn productivity of two bunchgrasses in an Idaho experimental range. International Journal of Wildland Fire 8: 15-20.

Clifton, N. A. 1981. Response to prescribed fire in a Wyoming big sagebrush / bluebunch wheatgrass habitat type. M. S. Thesis, University of Idaho, Moscow. 38 pp. 
Connelly, J. W., M. A. Schroeder, A. R. Sands and C. E. Braun. 2000. Guidelines to manage sage grouse populations and habitat. Wildlife Society Bulletin 28: 967-985.

Conrad, C. E. and C. E. Poulton. 1966. Effect of a wildfire on Idaho fescue and bluebunch wheatgrass. Journal of Range Management. 19: 138-141.

Cook, J. G., T. J. Hershey and L. L. Irwin. 1994. Vegetative response to burning on Wyoming mountain-shrub big game ranges. Journal of Range Management 47: 296-302.

Cooper, S. V., C. Jean and P. Hendricks. 2001. Biological survey of a prairie landscape in Montana's Glaciated Plains. Unpublished report to the Bureau of Land Management. Montana Natural Heritage Program, Helena, MT. 24 pp. plus appendices.

Cooper, S. V., C. Jean and B. L. Heidel. 1999. Plant associations and related botanical inventory of the Beaverhead Mountains Section, Montana. Unpublished report to the Bureau of Land Management. Montana Natural Heritage Program, Helena. 245 pp.

Daubenmire, R. 1959. A canopy-coverage method of vegetational analysis. Northwest Science 33: 4364.

Daubenmire, R. 1970. Steppe vegetation of Washington. Washington Agricultural Experiment Station Technical Bulletin 62. Pullman.

Daubenmire, R. 1975. Ecology of Artemisia tridentata ssp. tridentata in the state of Washington. Northwest Science 49: 24-35.

Daubenmire, R. 1976. The use of vegetation in assessing the productivity of forest lands. The Botanical Review 42(2): 115-143.
Doescher, P. S., R. F. Miller, S. R. Swanson and A. H. Winward. 1986. Identification of the Artemisia tridentata ssp. wyomingensis / Festuca idahoensis Habitat Type in eastern Oregeon. Northwest Science 60(1): 55-60.

Drut, M. S., W. H. Pyle and J. A. Crawford. 1994. Diets and food selection of sage grouse chicks in Oregon. Journal of Range Management 47: 90-93.

Dudley, J. L., and K. Lajtha. 1993. The effects of prescribed burning on nutrient availability and primary production in sandplain grasslands. American Midland Naturalist 130: 286-298.

Eichhorn, L. C. and C. R. Watts. 1984. Plant succession on burns in the river breaks of central Montana. Proceedings of the Montana Academy of Science 43: 21-34.

Eng, R. L. and P. Schladweiller. 1972. Sage grouse winter movements and habitat use in central Montana. Journal of Wildlife Management 36: 141146.

Ferguson, C. W. 1964. Annual rings in big sagebrush. University of Arizona Press, Tucson.

Fraas, W. W., C. L. Wambolt and M. R. Frisina. 1992. Prescribed fire effects on a bitterbrushmountain big sagebrush-bluebunch wheatgrass community. Pages 212-216 in: W. P. Clary et al., compilers. Proceedings-symposium on ecology and management of riparian shrub communities. USDA General Technical Report INT-289. Ogden, Utah.

Glenn-Lewin, D. C., L. A. Johnson, T. W. Jurik, A. Kosek, M. Leoscheke, and T. Rosburg. 1990. Fire in central North American grasslands: vegetative reproduction, seed germination and seedling establishment. Pages 28-45 in S. L. Collins and L. L. Wallace editors, Fire in central North American grasslands. University of Oklahoma Press, Norman. 
Gruell, G. E. 1980. Fire's influence on wildlife habitat on the Bridger-Teton National Forest, Wyoming, Volume II- changes and causes, management implications. USDA Forest Service Research Paper INT-252, Ogden, Utah.

Hansen, P. L. and G. R. Hoffman. 1987. The vegetation of the Grand River/Cedar River, Sioux, and Ashland Districts of the Custer National Forest: A habitat type classification. Gen. Tech. Rep. RM157. Fort Collins, CO: U. S. Dept. of Agriculture, Forest Service, Rocky Mountain Forest and Range Experiment Station. 68 pp.

Harniss, R. O. and R. B. Murray. 1973. 30 years of vegetal change following burning of sagebrushgrass range. Journal of Range Management 29: 167-168.

Harrington R. D., 2002. A historical perspective of Montana's sagebrush. Intermountain Journal of Sciences 8: 61-66.

Heidel, B. L., C. Jean and S. Crispin. 2001. Plant species of concern and plant associations of Powder River County, Montana. Report to the Bureau of Land Management. Montana Natural Heritage Program, Helena, MT. 23 pp. plus appendices.

Hironaka, M., M. A. Fosberg and A. H. Winward. Sagebrush-grass habitat types of southern Idaho. Forest, Wildlife and Range Experiment Station Bulletin 35. University of Idaho, Moscow. 44 pp.

Hobbs, R. J. and L. F. Huenneke. 1992.

Disturbance, diversity and invasion: implications for conservation. Conservation Biology 6: 324-337.

Hoffman, T. L. 1996. An ecological investigation of mountain big sagebrush in the Gardiner Basin.

M. S. Thesis, Montana State University, Bozeman.

Howe, H. F. 1994. Managing species diversity in tallgrass prairie: assumptions and implications.

Conservation Biology 8: 691-704.
Howe, H. F. 1995. Succession and fire season in experimental prairie plantings. Ecology 76: 19171925.

Hulbert, L. C. 1988. Causes of fire effects in tallgrass prairie. Ecology 69: 46-58.

Humphrey, L. D. 1984. Patterns and mechanisms of plant succession after fire on Artemisia-grass sites in southeastern Idaho. Vegetatio 57: 91-101.

Johnson, J. R. and G. F. Payne. 1968. Sagebrush reinvasion as affected by some environmental influences. Journal of Range Management 21: 209213.

Katzner, T. E. and K. L. Parker. 1997. Vegetative characteristics and size of home ranges used by pygmy rabbits (Brachylagus idahoensis) during winter. Journal of Mammalogy 78: 1063-1072.

Klebenow, D. A. 1969. Sage grouse nesting and brood habitat in Idaho. Journal of Wildlife Management 33: 649-661.

Klebenow, D. A. 1973. The habitat requirements of sage grouse and the role of fire in management. Proceedings of the Tall Timbers Fire Ecology Conference 12: 305-315.

Klebenow, D. A. and G. M. Gray. 1967. Food habits of juvenile sage grouse. Journal of Range Management 21: 80-83.

Knick, S. T. And J. T. Rottenberry 1995. Landscape characteristics of fragmented shrubsteppe habitats and breeding passerine birds. Conservation Biology 9: 1059-1071.

Kotanen, P. M., J. Bergelson and D. L. Hazlett. 1998. Habitats of native and exotic plants in Colorado shortgrass steppe: a comparative approach. Canadian Journal of Botany 76: 664672.

Laycock, W. A. 1991. Stable states and thresholds of range condition on North American rangelands: A viewpoint. Journal of Range Management 44: 427-433. 
Leach, M. K. and T. J. Givnish. 1996. Ecological determinants of species loss in remnant prairies. Science 273: 1555-1558.

Lesica, P. 1999. Effects of fire on the demography of the endangered, geophytic herb, Silene spaldingii. American Journal of Botany 86: 9961002.

Lesica, P. and S. V. Cooper. 1997. Presettlement vegetation of southern Beaverhead County, Montana. Montana Natural Heritage Program, Helena, MT.

McArthur, E. D. and B. L. Welch. 1982. Growth rate differences among big sagebrush [Artemisia tridentata] accessions and subspecies. Journal of Range Management 35: 396-401.

McCune, B. and D. Keon. 2002. Equations for potential annual direct incident radiation and heat load. Journal of Vegetation Science 13: 603-606.

Morris, M. S., R. G. Kelsey and D. Griggs. 1976. The geographic and ecological distribution of big sagebrush and other woody Artemisias in Montana. Proceedings of the Montana Academy of Sciences 36: 56-79.

Mueggler, W. F. and J. P. Blaisdell. 1958. Effects on associated species of burning, rotobeating, spraying, and railing sagebrush. Journal of Range Management 11: 61-66.

Mueggler, W. F. and W. L. Stewart. 1980. Grassland and shrubland habitat types of western Montana. USDA Forest Service General Technical Report INT-66, Ogden, Utah.

Mueller-Dombois, D. and H. Ellenberg. 1974. Aims and methods of vegetation ecology. John Wiley \& Sons, New York.

Natural Resource Conservation Service. 1998. Rangeland Resource Units Montana, Map Series No. 9850-141. State Office, Bozeman.
Nesser, J. A., G. L. Ford, C. L. Maynard and D. S. Page-Dumroese. 1997. Ecological units of the Northern Region: subsections. General Technical Report INT-GTR-369. Ogden, UT: U. S. Department of Agriculture, Forest Service, Intermountain Research Station. 88 pp.

Olson, R. A. and T. D. Whitson. 2002. Restoring structure in late-successional sagebrush communities by thinning with tebuthiuron. Restoration Ecology 10: 146-155.

Passey, H. B. and V. K. Hugie. 1962. Sagebrush on relict ranges in the Snake River plains and northern Great Basin. Journal of Range Management 15: 273-278.

Pechanec, J. F., G. Stewart, and J. P. Blaisdell. 1954. Sagebrush burning good and bad. USDA Farmers’ Bulletin No. 1948. Washington, DC.

Peek, J. M., R. A. Riggs and J. L. Lauer. 1979. Evaluation of fall burning on bighorn sheep winter range. Journal of Range Management 32: 430-432.

Perryman, B. L., A. M. Maier, A. L. Hild and R. A. Olson. 2001. Demographic characteristics of 3 Artemisia tridentata Nutt. subspecies. Journal of Range Management 54: 166-170.

Petersen, K. L. and L. B. Best. 1987. Effects of prescribed burning on nongame birds in a sagebrush community. Wildlife Society Bulletin 15: 317-329.

Peterson, J. G. 1970. The food habits and summer distribution of juvenile sage grouse in central Montana. Journal of Wildlife Management 34: 147155.

Pyle, W. H. and J. A. Crawford. 1996. Availability of foods for sage grouse chicks following prescribed fire in sagebrush-bitterbrush. Journal of Range Management 49: 320-324.

Rauscher, R. L. 1997. Status and distribution of the pygmy rabbit in Montana. Unpublished final report to Montana Department of Fish, Wildlife and Parks, Bozeman, MT. 
Robberecht, R. and G. E. Defosse. 1995. The relative sensitivity of two bunchgrass species to fire. International Journal of Wildland Fire 5: 127134.

Roscoe, J. W. 2002. Sage grouse movements in southwestern Montana. Intermountain Journal of Science 8: 94-104.

Singer, F. J. and M. K. Harter. 1996. Comparative effects of elk herbivory and 1988 fires on northern Yellowstone National Park grasslands. Ecological Applications 6: 185-199.

Thornton, P. E., S. W. Running and M. A. White. 1997. Generating surfaces of daily meteorological variables over large regions of complex terrain. Journal of Hydrology 190: 214-251.

Vanderhorst, J., S. V. Cooper and B. L. Heidel. 1998.Botanical and vegetation survey of Carter County, Montana. Unpublished report to the Bureau of Land Management. Montana Natural Heritage Program, Helena, MT. 116 pp. plus appendices.

Wallestad, R. 1971. Summer movements and habitat use by sage grouse broods in central Montana. Journal of Wildlife Management 35: 129135.

Wallestad, R. and D. Pyrah. 1974. Movement and nesting of sage grouse hens in central Montana. Journal of Wildlife Management 38: 630-637.

Wambolt, C. L. and G. F. Payne. 1986. An 18-year comparison of control methods for Wyoming big sagebrush in southwestern Montana. Journal of Range Management 39: 314-319.

Wambolt, C. L., K. S. Walhof and M. R. Frisina. 2001. Recovery of big sageebrush communities after burning in south-western Montana. Journal of Environmental Management 61: 243-252.

Weiss, N. T. and B. J. Verts. 1984. Habitat and distribution of pygmy rabbits (Sylvilagus idahoensis) in Oregon. Great Basin Naturalist 44: 563-571.
West, N. E. 1979. Basic synecological relationships of the sagebrush-dominated lands in the Great Basin and the Colorado Plateau. In: The sagebrush ecosystem: A symposium, pp. 33-41. Utah State University, College of Natural Resources, Logan, UT.

West, N. E. 2000. Synecology and disturbance regimes of sagebrush steppe ecosystems. Pages 15-26 in P. G. Entwistle et al., compilers. Proceedings: sagebrush steppe ecosystems symposium. USDI Bureau of Land Management Publication No. BLM/ID/PT-001001+1150. Boise, Idaho.

West, N. E. and M. A. Hassan. 1985. Recovery of sagebrush-grass vegetation following wildfire. Journal of Range Management 38: 131-134.

West, N. E., K. H. Rea and R. O. Harniss. 1979. Plant demographic studies in sagebrush-grass communities of southeastern Idaho. Ecology 60: 376-388.

Westoby, M., M. Walker and I. Noy-Meir. 1989. Opportunistic management for rangelands not at equilibrium. Journal of Range Management 42: 266-274.

Wiens, J. A. and J. T. Rottenberry. 1981. Habitat associations and community structure of birds in shrubsteppe environments. Ecological Monographs 51: 21-41.

Winward, A. H. 2004. Sagebrush of Colorado: Taxonomy, distribution, ecology and management. Colorado Division of Wildlife, Department of Natural Resources, Denver. 45 pp.

Wright, H. A., L. F. Neuenschwander and C. M. Britton. 1979. The role and use of fire in sagebrush-grass and pinyon-juniper plant communities: A state-of-the-art review. USDA General Technical Report INT-58. Ogden, Utah. 
Wrobleski, D. W. and J. B. Kauffman. 2003.

Initial effects of prescribed fire on morphology, abundance, and phenology of forbs in big sagebrush communities in southeastern Oregon. Restoration Ecology 11: 82-90.

Young, J. A. and R. A. Evans. 1978. Population dynamics after wildfires in sagebrush grasslands. Journal of Range Management 31: 283-289.

Young, J. A., and R. A. Evans. 1989. Dispersal and germination of big sagebrush (Artemisia tridentata) seeds. Weed Science 37: 201-206. 


\section{Appendix A. Global/State Rank Definitions}




\section{Heritage Program Ranks}

The international network of Natural Heritage Programs employs a standardized ranking system to denote global (range-wide) and state status. Species are assigned numeric ranks ranging from 1 to 5 , reflecting the relative degree to which they are "at-risk". Rank definitions are given below. A number of factors are considered in assigning ranks - the number, size and distribution of known "occurrences" or populations, population trends (if known), habitat sensitivity, and threat. Factors in a species' life history that make it especially vulnerable are also considered (e.g., dependence on a specific pollinator).

Global Rank Definitions (NatureServe 2003)

G1 Critically imperiled because of extreme rarity and/or other factors making it highly vulnerable to extinction

G2 Imperiled because of rarity and/or other factors making it vulnerable to extinction

G3 Vulnerable because of rarity or restricted range and/or other factors, even though it may be abundant at some of its locations

G4 Apparently secure, though it may be quite rare in parts of its range, especially at the periphery

G5 Demonstrably secure, though it may be quite rare in parts of its range, especially at the periphery

T1-5 Infraspecific Taxon (trinomial) - The status of infraspecific taxa (subspecies or varieties) are indicated by a “T-rank” following the species' global rank

\section{STATE RANK DEFinITIONS}

S1

S2

S3

S4

S5

At high risk because of extremely limited and potentially declining numbers, extent and/or habitat, making it highly vulnerable to extirpation in the state At risk because of very limited and potentially declining numbers, extent and/or habitat, making it vulnerable to extirpation in the state

Potentially at risk because of limited and potentially declining numbers, extent and/or habitat, even though it may be abundant in some areas

Uncommon but not rare (although it may be rare in parts of its range), and usually widespread. Apparently not vulnerable in most of its range, but possibly cause for long-term concern Common, widespread, and abundant (although it may be rare in parts of its range). Not vulnerable in most of its range

\section{Combination RANKS}

G\#G\# or S\#S\# Range Rank-A numeric range rank (e.g., G2G3) used to indicate uncertainty about the exact status of a taxon

\section{QUALIFIERS}

NR Not ranked this entity as a taxon at the current level is questionable; resolution of this uncertainty may result in change from a species to a subspecies or hybrid, or inclusion of this taxon in another taxon, with the resulting taxon having a lower-priority (numerically higher) conservation status rank 
Presumed Extinct-Species believed to be extinct throughout its range. Not located despite intensive searches of historical sites and other appropriate habitat, and virtually no likelihood that it will be rediscovered

Possibly Extinct-Species known from only historical occurrences, but may never-theless still be extant; further searching needed

Unrankable-Species currently unrankable due to lack of information or due to substantially conflicting information about status or trends

Hybrid—Entity not ranked because it represents an interspecific hybrid and not a species

Inexact Numeric Rank-Denotes inexact numeric rank

C

Captive or Cultivated Only_-Species at present is extant only in captivity or cultivation, or as a reintroduced population not yet established

Accidental-Species is accidental or casual in Montana, in other words, infrequent and outside usual range. Includes species (usually birds or butterflies) recorded once or only a few times at a location. A few of these species may have bred on the one or two occasions they were recorded

Z

Zero Occurrences-Species is present but lacking practical conservation concern in Montana because there are no definable occurrences, although the taxon is native and appears regularly in Montana

Potential-Potential that species occurs in Montana but no extant or historic occurrences are accepted

R Reported - Species reported in Montana but without a basis for either accepting or rejecting the report, or the report not yet reviewed locally. Some of these are very recent discoveries for which the program has not yet received first-hand information; others are old, obscure reports

SYN Synonym - Species reported as occurring in Montana, but the Montana Natural Heritage Program does not recognize the taxon; therefore the species is not assigned a rank

* $\quad$ A rank has been assigned and is under review. Contact the Montana Natural Heritage Program for assigned rank

B Breeding - Rank refers to the breeding population of the species in Montana Nonbreeding — Rank refers to the non-breeding population of the species in Montana 


\section{Appendix B. Descriptions of Artemisia tridentata SPP. tridentata Series Plant Associations Found \\ In The Study Area}




\section{Artemisia tridentata ssp. vaseyana / Festuca idahoensis / Geranium vicscossimum}

The Artemisia tridentata ssp. vaseyana / Festuca idahoensis / Geranium vicscossimum plant association occupies the most mesic of study area sagebrush habitats, either with the highest average precipitation (Table 1) or with favorable aspects. It was noted on various aspects, except southerly through southwesterly. Soils are deep loams and silt loams rated as optimum for production. At least one site was located in a collecting position (snow blowover via rotator winds and surface and subsurface flow augmentation). This association has the highest average shrub and spp. vaseyana cover, as well as the greatest average undergrowth cover, nearly $20 \%$ greater than the next most productive association, $A$. t. ssp. v. / F. idahoensis - Achnatherum occidentale ( / Idaho fescue - western needlegrass) and more than $45 \%$ greater than the least productive p. a., A. t. ssp. v. / Idaho fescue - western wheatgrass. With the exception of Artemisia tripartita (threetip sagebrush) as an opportunistic seral dominant and a very minor contribution by seral Tetradymia canescens (horsebrush), the shrub component of this association (in our limited sampling) is virtually exclusively dominated by spp. vaseyana and lacks the shrubs and subshrubs occurring in other mountain big sagebrush associations. As in other ssp. vaseyana-dominated associations, F. idahoensis is usually the dominant grass but Pseudoroegneria spicata (bluebunch wheatgrass) is conspicuously lacking or reduced to insignificant coverages. Replacing the bluebunch wheatgrass component are other relatively mesic graminoids, including, but not restricted to, Achnatherum richardsonii (Richardson's needlegrass), Achnatherum occidentale (western needlegrass), Elymus trachycaulus ssp. trachycaulus ( = Agropyron caninum, slender wheatgrass) perennial Bromus spp. (brome grasses), Melica spectabilis (purple oniongrass), Danthonia intermedia (timber oatgrass), Carex petasata, C. hoodii and C. raynoldsii (Liddon's, Hood's and Raynold's sedges) and the introduced rhizomatous, perennial Poa pratensis (Kentucky bluegrass). Most diagnostic of this type is the presence of mesic forbs, most particularly Geranium viscosissimum (sticky purple geranium), Helianthella uniflora (one-flower helianthella), Eriogonum umbellatum (sulphur-flower buckwheat), Potentilla arguta (tall cinquefoil), P. gracilis (slender cinquefoil) and P. glandulosa (sticky cinquefoil).

\section{Artemisia tridentata ssp. vaseyana / Festuca idahoensis - Achnatherum occidentale}

Although not supporting the relatively high shrub or undergrowth cover of the type described above, the ssp. vaseyana / F. idahoensis - A. occidentale plant association typically averages greater shrub and undergrowth canopy cover than other study area spp. vaseyana association (Table 2). It usually occurs at higher elevations (Table 1) with a higher precipitation model than other types, except for ssp. vaseyana / F. idahoensis / G. viscosssisimum. It differs from the ssp. vaseyana / F. idahoensis / G. viscossisimum type in having both a higher solar insolation load (by occurring predominantly on low to medium gradient slopes having southerly aspects) and lower soil moisture holding capacity (because of dominant sandy loams and loamy sands, average sand content 56\% versus 36\%). Although ssp. vaseyana cover for this type overlaps that of all other spp. vayseyana-dominated types, it ranges considerably above $40 \%$ and is typically greater than cover of the less mesic types. Achnatherum occidentale and F. idahoensis are both indicative and conspicuous components with the fescue usually dominant. Pseudoroegneria spicata (bluebunch wheatgrass) is $100 \%$ constant and occasionally a codominant, a fact that distinguishes this type from -/ F. idahoensis / G. viscosissimum and reflects its warmer and well-drained character. Poa pratensis (Kentucky bluegrass) is capable of rapidly acceding to undergrowth dominance with disturbance. Total perennial graminoid cover for this community has approximately the same average and range of values (Table 2) as the - / F. idahoensis $-P$. spicata association, the only other type well represented by sampling. Forb cover (Table 2) overlaps other mountain big sage communities except - / Idaho fescue - threadleaf sedge, but is typically greater than that of the more xeric communities and less than that of the more mesic - / Idaho fescue - sticky

Appendix $B-1$ 
geranium. Although some of the mesic forbs noted for the - / Idaho fescue - sticky geranium type may occur, their cover does not exceed 1\%. There is usually a variable mix of the following forbs, silky lupine (Lupinus sericeus), oblongleaf bluebells (Mertensia oblongifolia), longleaf fleabane (Erigeron corymbosum), Missouri goldenrod (Solidago missouriensis), common dandelion (Taraxacum officinale), arrowleaf balsamroot (Balsamorhiza sagittata) and twin arnica (Arnica sororia).

\section{Other Artemisia tridentata ssp. vaseyana types}

The - / Idaho fescue - threadleaf sedge (two plots) and - / Idaho fescue - western wheatgrass associations (three plots) were so infrequently sampled that they cannot be reliably characterized, nor have they been well describe in the literature (Cooper et al. 1999). Both types occurred in valley or basin settings on flat to gently rolling terrain with medium- to fine-textured soils (Table 1). Since the - / Idaho fescue - threadleaf sedge plots had so little cover of Idaho fescue, bluebunch wheatgrass and Richardson's needlegrass (none more than $2 \%$ cover, all grazing decreasers) and a comparative abundance (> 50 \% canopy cover) of threadleaf sedge (a notable increaser with grazing, [Mueggler and Stewart 1980, USDA, NRCS 2004]) suggests that these sites may have been significantly impacted by grazing. Despite its high cover, threadleaf sedge is at the extremes of its amplitude with regard to soil texture, which may indicate that grazing has reduced interspecies competition. The low forb cover for this association may suggest historical sheep grazing.

The - / Idaho fescue - western wheatgrass association, although typically dominated by Idaho fescue in the undergrowth, is characterized by the presence and often the abundance of rhizomatous wheatgrasses, western wheatgrass (Pascopyrum smithii = Agropyron smithii) and/or streambank wheatgrass (thickspike wheatgrass, Elymus lanceolatus $=$ A. dasystachyum), and scarcity of bluebunch wheatgrass. Despite abiotic parameters favorable for moderate to high production (Table 1) the - / Idaho fescue western wheatgrass association had the lowest average cover of perennial grasses of any mountain big sagebrush type, which may signal past incompatible grazing practices. Other indications of possible impacts of past grazing include higher cover values for two increaser species, Sandberg's bluegrass (Poa secunda) and plains reedgrass (Calamagrostis montanensis), than found for any other mountain big sagebrush association.

In relatively arid southwestern Montana the mountain big sagebrush / Idaho fescue - bluebunch wheatgrass association is the most extensive of all shrub-dominated communities. This association essentially corresponds to Mueggler and Stewart's (1980) Artemisia tridentata / Festuca idahoensis habitat type (the portion not including the sticky geranium [Geranium viscosissimum] phase). Our samples are a bit short on encompassing the abiotic range cited by these authors but clearly it represents the broadest elevation range (Table 1) of Mountain big sagebrush sites, occurring on slopes nearly flat to steeper than $40 \%$ and including variations in all cardinal directions. Although the range of values for annual precipitation is relatively broad, the average (Table 1 ) indicates this association to be relatively xeric. It should be noted that the 5 sites having the greatest average precipitation completely overlap the values from the two most mesic mountain big sagebrush associations. Four of the 5 sites occur at relatively low elevations on moderate to steep slopes with southern and western exposures and the other site was found at high elevation but occurs on thin, calcareous and excessively drained loamy sands. In contrast to the most mesic mountain big sage communities, which have only very sporadic occurrences of shrubs/subshrubs (other than sagebrush spp.), plots in this association had low cover ( $\leq 1 \%$ for any one species) for all shrub/subshrub species. Fringed sage (Artemisia frigida) was also present in about half of the plots. Although the average and range of values for perennial grass cover for this association closely approximates those of the two most mesic associations, the average and range of forb cover values is distinctly lower (Table 2). Idaho fescue is consistently the undergrowth dominant with cover 
averaging 30\% and ranging from 24 to 38\%, whereas bluebunch wheatgrass, perhaps as a consequence of being much more palatable (these two species are rated fair and excellent, respectively [Mueggler and Stewart 1980]), exhibits a much wider range of cover (1 to 26\%) and lower average cover (8\%). These values compare favorably to those of Mueggler and Stewart (1980) who found 39 and 5\% average canopy cover for Idaho fescue and bluebunch wheatgrass, respectively, on relatively disturbance-free sites. 


\section{Appendix C. Constancy / Cover Tables}

See key at end showing correspondence between six-character codes used in tables and latin binomial and common name (according to USDA PLANTS Database) 


\begin{tabular}{|c|c|c|c|c|c|c|c|c|c|c|c|c|c|c|c|c|c|c|c|c|}
\hline \multirow{2}{*}{\begin{tabular}{|l} 
SPECIES \\
Shrubs
\end{tabular}} & \multicolumn{2}{|c|}{$\begin{array}{c}\text { ARTTST/ } \\
\text { HESCOM-B } \\
n=1\end{array}$} & \multicolumn{2}{|c|}{$\begin{array}{c}\text { ARTTST/ } \\
\text { HESCOM-C } \\
n=1\end{array}$} & \multicolumn{2}{|c|}{$\begin{array}{c}\text { ARTTST/ } \\
\text { PASSMI-B } \\
n=3\end{array}$} & \multicolumn{2}{|c|}{$\begin{array}{c}\text { ARTGST/ } \\
\text { PASSMI-C } \\
n=3\end{array}$} & \multicolumn{2}{|c|}{$\begin{array}{c}\text { ARTTSV/FESIDA- } \\
\text { ACHOCC-B } \\
n=8\end{array}$} & \multicolumn{2}{|c|}{$\begin{array}{c}\text { ARTTSV/FESIDA- } \\
\text { ACHOCC-C } \\
n=8\end{array}$} & \multicolumn{2}{|c|}{$\begin{array}{c}\text { ARTTSV/FESID } \\
\text { A-CARFIL-B } \\
n=1\end{array}$} & \multicolumn{2}{|c|}{$\begin{array}{c}\text { ARTTSV/FESID } \\
\text { A-CARFIL-C } \\
n=1 \\
\end{array}$} & \multicolumn{2}{|c|}{$\begin{array}{c}\text { ARTTSV/FESID } \\
\text { A-GERVIS-B } \\
n=7\end{array}$} & \multicolumn{2}{|c|}{$\begin{array}{c}\text { ARTTSV/FESID } \\
\text { A-GERVIS-C } \\
n=6\end{array}$} \\
\hline & CON & $\mathrm{cov}$ & CON & $\mathrm{cov}$ & $\mathrm{CON}$ & $\mathrm{cov}$ & $\mathrm{CON}$ & cov & $\mathrm{CON}$ & $\mathrm{cov}$ & $\mathrm{CON}$ & cov & CON & $\mathrm{cov}$ & $\mathrm{CON}$ & $\mathrm{cov}$ & CON & cov & CON & $\mathrm{cov}$ \\
\hline ARTFRI & 0 & 0.0 & 0 & 0.0 & 0 & 0.0 & 0.66 & 0.2 & 0.12 & 0.1 & 0.12 & 3.8 & 0 & 0.0 & 0 & 0.0 & 0 & 0.0 & 0 & 0.0 \\
\hline ARTTRP & 1 & 25.7 & 1 & 0.3 & 0 & 0.0 & 0 & 0.0 & 0.25 & 11.3 & 0.12 & 2.5 & 0 & 0.0 & 0 & 0.0 & 0.28 & 5.0 & 0.5 & 6.1 \\
\hline ARTTST & 0 & 0.0 & 1 & 24.7 & 1 & 15.8 & 1 & 19.1 & 0 & 0.0 & 0 & 0.0 & 0 & 0.0 & 0 & 0.0 & 0 & 0.0 & 0 & 0.0 \\
\hline ARTTSV & 1 & 10.0 & 0 & 0.0 & 0 & 0.0 & 0 & 0.0 & 0.87 & 6.8 & 1 & 30.1 & 1 & 26.4 & 1 & 28.5 & 0.85 & 9.8 & 1 & 30.6 \\
\hline ARTTSW & 0 & 0.0 & 0 & 0.0 & 0 & 0.0 & 0 & 0.0 & 0 & 0.0 & 0 & 0.0 & 0 & 0.0 & 0 & 0.0 & 0 & 0.0 & 0 & 0.0 \\
\hline BERREP & 0 & 0.0 & 0 & 0.0 & 0 & 0.0 & 0 & 0.0 & 0 & 0.0 & 0.12 & 0.1 & 0 & 0.0 & 0 & 0.0 & 0 & 0.0 & 0 & 0.0 \\
\hline CHRNAU & 0 & 0.0 & 0 & 0.0 & 0.33 & 0.7 & 0.33 & 5.1 & 0.12 & 7.5 & 0.12 & 2.7 & 0 & 0.0 & 0 & 0.0 & 0.15 & 0.5 & 0.16 & 0.4 \\
\hline CHRVIS & 0 & 0.0 & 0 & 0.0 & 0.33 & 14.1 & 0.66 & 3.8 & 0.5 & 0.3 & 0 & 0.0 & 0 & 0.0 & 1 & 0.1 & 0 & 0.0 & 0.16 & 0.2 \\
\hline GUTSAR & 0 & 0.0 & 0 & 0.0 & 0 & 0.0 & 0.33 & 0.1 & 0 & 0.0 & 0 & 0.0 & 0 & 0.0 & 0 & 0.0 & 0 & 0.0 & 0 & 0.0 \\
\hline JUNSCO & 0 & 0.0 & 0 & 0.0 & 0 & 0.0 & 0 & 0.0 & 0 & 0.0 & 0 & 0.0 & 0 & 0.0 & 0 & 0.0 & 0 & 0.0 & 0 & 0.0 \\
\hline KRALAN & 0 & 0.0 & 0 & 0.0 & 0 & 0.0 & 0 & 0.0 & 0 & 0.0 & 0 & 0.0 & 0 & 0.0 & 0 & 0.0 & 0 & 0.0 & 0 & 0.0 \\
\hline OPUFRA & 1 & 0.1 & 1 & 4.4 & 0 & 0.0 & 0 & 0.0 & 0 & 0.0 & 0 & 0.0 & 0 & 0.0 & 0 & 0.0 & 0 & 0.0 & 0 & 0.0 \\
\hline OPUPOL & 0 & 0.0 & 0 & 0.0 & 0 & 0.0 & 0.66 & 1.2 & 0 & 0.0 & 0 & 0.0 & 0 & 0.0 & 0 & 0.0 & 0 & 0.0 & 0 & 0.0 \\
\hline SARVER & 0 & 0.0 & 0 & 0.0 & 0.66 & 0.7 & 0.66 & 2.1 & 0 & 0.0 & 0 & 0.0 & 0 & 0.0 & 0 & 0.0 & 0 & 0.0 & 0 & 0.0 \\
\hline SYMOCC & 0 & 0.0 & 0 & 0.0 & 0 & 0.0 & 0.33 & 0.1 & 0 & 0.0 & 0 & 0.0 & 0 & 0.0 & 0 & 0.0 & 0 & 0.0 & 0.16 & 0.5 \\
\hline SYMORE & 0 & 0.0 & 0 & 0.0 & 0 & 0.0 & 0 & 0.0 & 0.25 & 0.7 & 0.25 & 2.0 & 0 & 0.0 & 0 & 0.0 & 0 & 0.0 & 0 & 0.0 \\
\hline TETCAN & 0 & 0.0 & 0 & 0.0 & 0 & 0.0 & 0 & 0.0 & 0.37 & 1.5 & 0 & 0.0 & 0 & 0.0 & 0 & 0.0 & 0.28 & 1.5 & 0.33 & 0.4 \\
\hline
\end{tabular}

\begin{tabular}{|c|c|c|c|c|c|c|c|c|c|c|c|c|c|c|c|c|c|c|c|c|}
\hline Graminoids & CON & cov & CON & cov & CON & cov & CON & $\mathrm{COV}$ & CON & $\mathrm{COV}$ & CON & $\mathrm{COV}$ & CON & cov & CON & cov & CON & cov & CON & $\mathrm{cov}$ \\
\hline \begin{tabular}{|l|l} 
ACHHYM \\
\end{tabular} & 0 & 0.0 & 0 & 0.0 & 0 & 0.0 & 0.33 & 0.7 & 0 & 0.0 & 0 & 0.0 & 0 & 0.0 & 0 & 0.0 & 0 & 0.0 & 0 & 0.0 \\
\hline $\mathrm{ACHOCC}$ & 0 & 0.0 & 0 & 0.0 & 0.33 & 0.1 & 0 & 0.0 & 0.75 & 14.7 & 1 & 11.6 & 0 & 0.0 & 0 & 0.0 & 0.57 & 15.5 & 0.83 & 7.6 \\
\hline ACHRIC & 0 & 0.0 & 0 & 0.0 & 0 & 0.0 & 0 & 0.0 & 0 & 0.0 & 0.12 & 0.2 & 1 & 3.3 & 1 & 2.5 & 0.28 & 20.5 & 0.33 & 9.6 \\
\hline AGRHUM & 0 & 0.0 & 0 & 0.0 & 0 & 0.0 & 0 & 0.0 & 0 & 0.0 & 0 & 0.0 & 0 & 0.0 & 0 & 0.0 & 0.14 & 0.3 & 0 & 0.0 \\
\hline BOUGRA & 0 & 0.0 & 0 & 0.0 & 0.33 & 2.1 & 0 & 0.0 & 0 & 0.0 & 0 & 0.0 & 0 & 0.0 & 0 & 0.0 & 0 & 0.0 & 0 & 0.0 \\
\hline BROANO & 0 & 0.0 & 0 & 0.0 & 0 & 0.0 & 0 & 0.0 & 0.12 & 2.9 & 0.25 & 2.5 & 0 & 0.0 & 0 & 0.0 & 0.28 & 3.0 & 0.33 & 0.4 \\
\hline BROCAR & 0 & 0.0 & 0 & 0.0 & 0 & 0.0 & 0 & 0.0 & 0.12 & 1.3 & 0.12 & 0.1 & 0 & 0.0 & 0 & 0.0 & 0 & 0.0 & 0.16 & 0.1 \\
\hline BROINE & 0 & 0.0 & 0 & 0.0 & 0 & 0.0 & 0 & 0.0 & 0 & 0.0 & 0.12 & 0.1 & 0 & 0.0 & 0 & 0.0 & 0 & 0.0 & 0 & 0.0 \\
\hline BROMUS & 0 & 0.0 & 0 & 0.0 & 0 & 0.0 & 0 & 0.0 & 0 & 0.0 & 0 & 0.0 & 0 & 0.0 & 0 & 0.0 & 0 & 0.0 & 0 & 0.0 \\
\hline BROTEC & 0 & 0.0 & 0 & 0.0 & 0.66 & 0.1 & 0.33 & 0.3 & 0.37 & 3.2 & 0.25 & 0.2 & 0 & 0.0 & 0 & 0.0 & 0.42 & 0.3 & 0 & 0.0 \\
\hline CALMON & 0 & 0.0 & 0 & 0.0 & 0 & 0.0 & 0 & 0.0 & 0 & 0.0 & 0 & 0.0 & 1 & 1.4 & 1 & 0.7 & 0.14 & 0.3 & 0 & 0.0 \\
\hline CALPUR & 0 & 0.0 & 0 & 0.0 & 0 & 0.0 & 0 & 0.0 & 0 & 0.0 & 0 & 0.0 & 0 & 0.0 & 0 & 0.0 & 0 & 0.0 & 0 & 0.0 \\
\hline CARDUR & 0 & 0.0 & 0 & 0.0 & 0 & 0.0 & 0.33 & 0.1 & 0 & 0.0 & 0.12 & 0.1 & 0 & 0.0 & 0 & 0.0 & 0.14 & 0.1 & 0 & 0.0 \\
\hline CAREX & 0 & 0.0 & 0 & 0.0 & 0 & 0.0 & 0 & 0.0 & 0 & 0.0 & 0 & 0.0 & 0 & 0.0 & 0 & 0.0 & 0 & 0.0 & 0 & 0.0 \\
\hline CARFIL & 0 & 0.0 & 0 & 0.0 & 0 & 0.0 & 0 & 0.0 & 0 & 0.0 & 0 & 0.0 & 1 & 58.0 & 1 & 53.0 & 0.85 & 10.0 & 0.66 & 4.6 \\
\hline CARGEY & 0 & 0.0 & 0 & 0.0 & 0 & 0.0 & 0 & 0.0 & 0 & 0.0 & 0 & 0.0 & 0 & 0.0 & 0 & 0.0 & 0.14 & 0.3 & 0.16 & 11.0 \\
\hline CARHOO & 0 & 0.0 & 0 & 0.0 & 0 & 0.0 & 0 & 0.0 & 0.12 & 3.1 & 0 & 0.0 & 0 & 0.0 & 0 & 0.0 & 0 & 0.0 & 0.16 & 2.3 \\
\hline CARPET & 0 & 0.0 & 0 & 0.0 & 0 & 0.0 & 0 & 0.0 & 0.75 & 0.1 & 0.75 & 0.3 & 0 & 0.0 & 0 & 0.0 & 0.71 & 1.1 & 0.66 & 0.8 \\
\hline CARROI & 1 & 3.4 & 1 & 0.5 & 0 & 0.0 & 0 & 0.0 & 0.12 & 0.4 & 0.25 & 4.0 & 0 & 0.0 & 0 & 0.0 & 0 & 0.0 & 0.33 & 0.2 \\
\hline CARVAL & 0 & 0.0 & 0 & 0.0 & 0 & 0.0 & 0 & 0.0 & 0.62 & 0.2 & 0.37 & 1.3 & 0 & 0.0 & 0 & 0.0 & 0.42 & 1.0 & 0.5 & 0.2 \\
\hline DACGLO & 0 & 0.0 & 0 & 0.0 & 0 & 0.0 & 0 & 0.0 & 0 & 0.0 & 0 & 0.0 & 0 & 0.0 & 0 & 0.0 & 0.28 & 3.5 & 0 & 0.0 \\
\hline DANINT & 0 & 0.0 & 0 & 0.0 & 0 & 0.0 & 0 & 0.0 & 0 & 0.0 & 0.12 & 3.2 & 1 & 0.1 & 1 & 0.1 & 0.14 & 0.5 & 0.16 & 0.3 \\
\hline DANUNI & 0 & 0.0 & 0 & 0.0 & 0 & 0.0 & 0 & 0.0 & 0 & 0.0 & 0.12 & 0.3 & 0 & 0.0 & 0 & 0.0 & 0 & 0.0 & 0.33 & 0.1 \\
\hline DISSTR & 0 & 0.0 & 0 & 0.0 & 0.33 & 0.9 & 0.33 & 1.9 & 0 & 0.0 & 0 & 0.0 & 0 & 0.0 & 0 & 0.0 & 0 & 0.0 & 0 & 0.0 \\
\hline ELYELY & 0 & 0.0 & 0 & 0.0 & 0 & 0.0 & 0.33 & 0.4 & 0 & 0.0 & 0.12 & 1.0 & 0 & 0.0 & 0 & 0.0 & 0.14 & 0.4 & 0 & 0.0 \\
\hline ELYLAN & 0 & 0.0 & 1 & 1.1 & 0 & 0.0 & 0 & 0.0 & 0 & 0.0 & 0 & 0.0 & 0 & 0.0 & 0 & 0.0 & 0.42 & 8.0 & 0.33 & 5.2 \\
\hline ELYTRA & 0 & 0.0 & 0 & 0.0 & 0 & 0.0 & 0 & 0.0 & 0.12 & 0.2 & 0 & 0.0 & 0 & 0.0 & 0 & 0.0 & 0.57 & 2.6 & 0.5 & 0.2 \\
\hline FESIDA & 1 & 0.2 & 0 & 0.0 & 0.33 & 1.1 & 0.33 & 0.1 & 1 & 19.6 & 1 & 16.4 & 1 & 4.2 & 1 & 1.2 & 1 & 8.7 & 1 & 12.9 \\
\hline HESCOM & 1 & 14.6 & 1 & 26.0 & 0.66 & 0.3 & 0.66 & 1.5 & 0.12 & 56.0 & 0.12 & 0.7 & 0 & 0.0 & 0 & 0.0 & 0.57 & 17.1 & 0.5 & 11.9 \\
\hline KOEMAC & 1 & 1.0 & 0 & 0.0 & 0 & 0.0 & 0.66 & 0.1 & 0.62 & 0.4 & 0.5 & 0.3 & 1 & 0.2 & 1 & 0.2 & 0.71 & 1.0 & 0.66 & 0.6 \\
\hline LEYCIN & 0 & 0.0 & 0 & 0.0 & 0.33 & 24.6 & 0.33 & 2.0 & 0.12 & 7.6 & 0.12 & 4.8 & 0 & 0.0 & 0 & 0.0 & 0.14 & 0.7 & 0.33 & 2.0 \\
\hline MELBUL & 0 & 0.0 & 0 & 0.0 & 0 & 0.0 & 0 & 0.0 & 0 & 0.0 & 0 & 0.0 & 0 & 0.0 & 0 & 0.0 & 0.14 & 0.1 & 0 & 0.0 \\
\hline MELSPE & 0 & 0.0 & 0 & 0.0 & 0 & 0.0 & 0 & 0.0 & 0 & 0.0 & 0 & 0.0 & 0 & 0.0 & 0 & 0.0 & 0 & 0.0 & 0.33 & 0.2 \\
\hline MUHRIC & 0 & 0.0 & 0 & 0.0 & 0 & 0.0 & 0 & 0.0 & 0 & 0.0 & 0 & 0.0 & 1 & 0.1 & 1 & 0.1 & 0 & 0.0 & 0 & 0.0 \\
\hline PASSMI & 0 & 0.0 & 0 & 0.0 & 0.66 & 36.0 & 1 & 22.3 & 0.12 & 2.3 & 0.12 & 0.1 & 0 & 0.0 & 0 & 0.0 & 0 & 0.0 & 0 & 0.0 \\
\hline PHLPRA & 0 & 0.0 & 0 & 0.0 & 0 & 0.0 & 0 & 0.0 & 0 & 0.0 & 0.12 & 0.3 & 0 & 0.0 & 0 & 0.0 & 0 & 0.0 & 0 & 0.0 \\
\hline POACUS & 0 & 0.0 & 1 & 0.1 & 0 & 0.0 & 0 & 0.0 & 0.12 & 0.2 & 0.12 & 0.1 & 0 & 0.0 & 0 & 0.0 & 0.28 & 0.2 & 0 & 0.0 \\
\hline POAPRA & 0 & 0.0 & 1 & 0.3 & 0.33 & 15.6 & 0.33 & 19.6 & 0.75 & 5.3 & 0.87 & 7.7 & 0 & 0.0 & 0 & 0.0 & 0.71 & 4.2 & 1 & 9.1 \\
\hline POASEC & 1 & 0.2 & 0 & 0.0 & 0.33 & 14.6 & 0.33 & 23.4 & 1 & 1.0 & 0.62 & 0.2 & 1 & 0.1 & 1 & 0.2 & 0.71 & 2.3 & 0.83 & 1.1 \\
\hline POAXXX & 0 & 0.0 & 0 & 0.0 & 0 & 0.0 & 0 & 0.0 & 0.12 & 0.2 & 0 & 0.0 & 0 & 0.0 & 0 & 0.0 & 0 & 0.0 & 0 & 0.0 \\
\hline PSESPI & 0 & 0.0 & 0 & 0.0 & 0 & 0.0 & 0 & 0.0 & 1 & 9.6 & 1 & 5.9 & 0 & 0.0 & 1 & 0.5 & 0.42 & 13.6 & 0.5 & 5.9 \\
\hline SPOCRY & 0 & 0.0 & 0 & 0.0 & 0.33 & 0.5 & 0.33 & 2.5 & 0 & 0.0 & 0 & 0.0 & 0 & 0.0 & 0 & 0.0 & 0 & 0.0 & 0 & 0.0 \\
\hline
\end{tabular}




\begin{tabular}{|c|c|c|c|c|c|c|c|c|c|c|c|c|c|c|c|c|c|c|c|c|}
\hline \multirow{2}{*}{$\begin{array}{l}\text { SPECIES } \\
\text { Forbs }\end{array}$} & \multicolumn{2}{|c|}{$\begin{array}{c}\text { ARTTST/ } \\
\text { HESCOM-B } \\
n=1\end{array}$} & \multicolumn{2}{|c|}{$\begin{array}{c}\text { ARTTST/ } \\
\text { HESCOM-C } \\
n=1\end{array}$} & \multicolumn{2}{|c|}{$\begin{array}{c}\text { ARTTST/ } \\
\text { PASSMl-B } \\
n=3\end{array}$} & \multicolumn{2}{|c|}{$\begin{array}{c}\text { ARTGST/ } \\
\text { PASSMI-C } \\
n=3\end{array}$} & $\begin{array}{r}\text { ARTTSV } \\
\text { ACHC } \\
n\end{array}$ & $\begin{array}{l}\text { ESIDA- } \\
\text { CC-B } \\
B\end{array}$ & $\begin{array}{r}\text { ARTTSV } \\
\text { ACHC } \\
n\end{array}$ & $\begin{array}{l}\text { EESIDA- } \\
\text { CC-C } \\
8\end{array}$ & $\begin{array}{r}\text { ARTTS } \\
\text { A-CAF } \\
n=\end{array}$ & $\begin{array}{l}\text { /FESID } \\
\text { FIL-B } \\
1\end{array}$ & $\begin{array}{r}\text { ARTTS } \\
\text { A-CAF } \\
n=\end{array}$ & $\begin{array}{l}\text { /FESID } \\
\text { FIL-C } \\
1\end{array}$ & $\begin{array}{r}\text { ARTTS } \\
\text { A-GE } \\
n=2\end{array}$ & $\begin{array}{l}\text { /FESID } \\
\text { VIS-B } \\
7\end{array}$ & $\begin{array}{r}\text { ARTTSV } \\
\text { A-GER } \\
n=\end{array}$ & $\begin{array}{l}\text { //FESID } \\
\text { VIS-C } \\
6\end{array}$ \\
\hline & CON & cov & CON & $\mathrm{cov}$ & CON & $\mathrm{cov}$ & CON & cov & CON & $\mathrm{cov}$ & CON & $\operatorname{cov}$ & CON & $\operatorname{cov}$ & CON & $\operatorname{cov}$ & $\mathrm{CON}$ & cov & CON & cov \\
\hline ACHMIL & 0 & 0.0 & 0 & 0.0 & 0 & 0.0 & 0 & 0.0 & 1 & 1.7 & 1 & 1.1 & 1 & 0.3 & 1 & 0.2 & 1 & 4.1 & 0.83 & 1.4 \\
\hline AGOGLA & 0 & 0.0 & 0 & 0.0 & 0 & 0.0 & 0 & 0.0 & 0.37 & 1.5 & 1 & 0.7 & 0 & 0.0 & 0 & 0.0 & 0.42 & 6.5 & 0.66 & 3.8 \\
\hline AGOSER & 0 & 0.0 & 0 & 0.0 & 0 & 0.0 & 0 & 0.0 & 0.12 & 0.5 & 0 & 0.0 & 0 & 0.0 & 0 & 0.0 & 0 & 0.0 & 0 & 0.0 \\
\hline ALLCER & 0 & 0.0 & 0 & 0.0 & 0 & 0.0 & 0 & 0.0 & 0.12 & 0.2 & 0.12 & 0.1 & 0 & 0.0 & 0 & 0.0 & 0 & 0.0 & 0 & 0.0 \\
\hline ALLIUM & 0 & 0.0 & 0 & 0.0 & 0.33 & 0.1 & 0 & 0.0 & 0 & 0.0 & 0 & 0.0 & 0 & 0.0 & 0 & 0.0 & 0 & 0.0 & 0 & 0.0 \\
\hline ALLTEX & 0 & 0.0 & 0 & 0.0 & 0 & 0.0 & 0 & 0.0 & 0 & 0.0 & 0 & 0.0 & 0 & 0.0 & 0 & 0.0 & 0 & 0.0 & 0 & 0.0 \\
\hline ALYDES & 0 & 0.0 & 0 & 0.0 & 0.33 & 0.2 & 0.33 & 0.2 & 0 & 0.0 & 0 & 0.0 & 0 & 0.0 & 0 & 0.0 & 0 & 0.0 & 0 & 0.0 \\
\hline ANDOCC & 0 & 0.0 & 0 & 0.0 & 0 & 0.0 & 0 & 0.0 & 0.12 & 0.1 & 0 & 0.0 & 0 & 0.0 & 0 & 0.0 & 0 & 0.0 & 0 & 0.0 \\
\hline ANDSEP & 0 & 0.0 & 0 & 0.0 & 0 & 0.0 & 0 & 0.0 & 0 & 0.0 & 0 & 0.0 & 0 & 0.0 & 0 & 0.0 & 0 & 0.0 & 0 & 0.0 \\
\hline ANEMUL & 0 & 0.0 & 0 & 0.0 & 0 & 0.0 & 0 & 0.0 & 0 & 0.0 & 0 & 0.0 & 0 & 0.0 & 0 & 0.0 & 0.14 & 0.1 & 0.16 & 0.4 \\
\hline ANEPAT & 0 & 0.0 & 0 & 0.0 & 0 & 0.0 & 0 & 0.0 & 0 & 0.0 & 0 & 0.0 & 0 & 0.0 & 0 & 0.0 & 0.28 & 1.4 & 0 & 0.0 \\
\hline ANTANA & 0 & 0.0 & 0 & 0.0 & 0 & 0.0 & 0 & 0.0 & 0 & 0.0 & 0.12 & 1.3 & 0 & 0.0 & 0 & 0.0 & 0.28 & 0.4 & 0 & 0.0 \\
\hline ANTROS & 0 & 0.0 & 0 & 0.0 & 0 & 0.0 & 0.33 & 0.1 & 0.75 & 0.6 & 0.87 & 0.6 & 1 & 1.5 & 1 & 5.5 & 1 & 0.7 & 0.83 & 1.9 \\
\hline ANTUMB & 0 & 0.0 & 0 & 0.0 & 0 & 0.0 & 0 & 0.0 & 0.12 & 0.4 & 0 & 0.0 & 0 & 0.0 & 0 & 0.0 & 0 & 0.0 & 0 & 0.0 \\
\hline ARABIS & 1 & 0.1 & 0 & 0.0 & 0.33 & 0.1 & 0 & 0.0 & 0 & 0.0 & 0 & 0.0 & 0 & 0.0 & 0 & 0.0 & 0.14 & 0.2 & 0.16 & 0.2 \\
\hline ARACAP & 0 & 0.0 & 0 & 0.0 & 0 & 0.0 & 0 & 0.0 & 0 & 0.0 & 0 & 0.0 & 0 & 0.0 & 0 & 0.0 & 0 & 0.0 & 0 & 0.0 \\
\hline ARADRU & 0 & 0.0 & 0 & 0.0 & 0 & 0.0 & 0.33 & 0.2 & 0.5 & 0.2 & 0.37 & 0.1 & 0 & 0.0 & 0 & 0.0 & 0.42 & 0.1 & 0.16 & 0.1 \\
\hline ARAGLA & 0 & 0.0 & 0 & 0.0 & 0 & 0.0 & 0 & 0.0 & 0.12 & 0.1 & 0 & 0.0 & 0 & 0.0 & 0 & 0.0 & 0 & 0.0 & 0 & 0.0 \\
\hline ARAHOL & 0 & 0.0 & 0 & 0.0 & 0 & 0.0 & 0 & 0.0 & 0 & 0.0 & 0 & 0.0 & 0 & 0.0 & 0 & 0.0 & 0 & 0.0 & 0 & 0.0 \\
\hline ARANUT & 0 & 0.0 & 0 & 0.0 & 0 & 0.0 & 0 & 0.0 & 0.37 & 0.1 & 0 & 0.0 & 0 & 0.0 & 0 & 0.0 & 0.28 & 0.2 & 0.33 & 0.1 \\
\hline ARASPA & 0 & 0.0 & 0 & 0.0 & 0 & 0.0 & 0 & 0.0 & 0 & 0.0 & 0 & 0.0 & 0 & 0.0 & 0 & 0.0 & 0.14 & 0.4 & 0 & 0.0 \\
\hline ARECAP & 0 & 0.0 & 0 & 0.0 & 0 & 0.0 & 0 & 0.0 & 0.5 & 1.0 & 0.62 & 1.0 & 0 & 0.0 & 0 & 0.0 & 0.71 & 0.3 & 0.66 & 0.4 \\
\hline ARECON & 0 & 0.0 & 0 & 0.0 & 0 & 0.0 & 0 & 0.0 & 0 & 0.0 & 0 & 0.0 & 0 & 0.0 & 0 & 0.0 & 0 & 0.0 & 0 & 0.0 \\
\hline AREKIN & 0 & 0.0 & 0 & 0.0 & 0 & 0.0 & 0 & 0.0 & 0 & 0.0 & 0 & 0.0 & 0 & 0.0 & 0 & 0.0 & 0 & 0.0 & 0 & 0.0 \\
\hline ARNSOR & 0 & 0.0 & 0 & 0.0 & 0 & 0.0 & 0 & 0.0 & 0.75 & 3.0 & 0.87 & 1.1 & 1 & 0.4 & 1 & 0.8 & 0.42 & 1.5 & 0.66 & 0.6 \\
\hline ARTARB & 0 & 0.0 & 0 & 0.0 & 0 & 0.0 & 0 & 0.0 & 0 & 0.0 & 0 & 0.0 & 0 & 0.0 & 0 & 0.0 & 0 & 0.0 & 0 & 0.0 \\
\hline ARTLUD & 0 & 0.0 & 0 & 0.0 & 0 & 0.0 & 0 & 0.0 & 0.12 & 12.7 & 0.25 & 4.0 & 0 & 0.0 & 0 & 0.0 & 0.14 & 0.9 & 0.16 & 0.1 \\
\hline ASTADS & 0 & 0.0 & 0 & 0.0 & 0 & 0.0 & 0 & 0.0 & 0 & 0.0 & 0 & 0.0 & 0 & 0.0 & 0 & 0.0 & 0 & 0.0 & 0.16 & 0.2 \\
\hline ASTAGR & 0 & 0.0 & 0 & 0.0 & 0 & 0.0 & 0 & 0.0 & 0.12 & 0.1 & 0.12 & 0.1 & 0 & 0.0 & 0 & 0.0 & 0.14 & 0.1 & 0.16 & 0.1 \\
\hline ASTATR & 0 & 0.0 & 0 & 0.0 & 0 & 0.0 & 0 & 0.0 & 0 & 0.0 & 0 & 0.0 & 0 & 0.0 & 0 & 0.0 & 0 & 0.0 & 0 & 0.0 \\
\hline $\mathrm{ASTCHI}$ & 0 & 0.0 & 0 & 0.0 & 0 & 0.0 & 0 & 0.0 & 0 & 0.0 & 0 & 0.0 & 0 & 0.0 & 0 & 0.0 & 0.14 & 0.1 & 0 & 0.0 \\
\hline ASTER & 0 & 0.0 & 0 & 0.0 & 0 & 0.0 & 0 & 0.0 & 0 & 0.0 & 0 & 0.0 & 0 & 0.0 & 0 & 0.0 & 0.14 & 0.1 & 0.16 & 0.1 \\
\hline ASTFAL & 0 & 0.0 & 0 & 0.0 & 0 & 0.0 & 0 & 0.0 & 0.25 & 1.7 & 0 & 0.0 & 0 & 0.0 & 0 & 0.0 & 0.28 & 0.5 & 0 & 0.0 \\
\hline ASTLEN & 0 & 0.0 & 0 & 0.0 & 0 & 0.0 & 0 & 0.0 & 0 & 0.0 & 0 & 0.0 & 0 & 0.0 & 0 & 0.0 & 0 & 0.0 & 0 & 0.0 \\
\hline ASTMIS & 0 & 0.0 & 0 & 0.0 & 0 & 0.0 & 0 & 0.0 & 0.25 & 0.6 & 0 & 0.0 & 0 & 0.0 & 0 & 0.0 & 0.42 & 0.9 & 0.33 & 1.0 \\
\hline ASTPUR & 0 & 0.0 & 0 & 0.0 & 0 & 0.0 & 0 & 0.0 & 0 & 0.0 & 0 & 0.0 & 0 & 0.0 & 0 & 0.0 & 0 & 0.0 & 0 & 0.0 \\
\hline ASTRAD & 0 & 0.0 & 0 & 0.0 & 0 & 0.0 & 0 & 0.0 & 0 & 0.0 & 0 & 0.0 & 0 & 0.0 & 0 & 0.0 & 0.14 & 0.1 & 0 & 0.0 \\
\hline ASTRAG & 0 & 0.0 & 0 & 0.0 & 0 & 0.0 & 0.33 & 0.1 & 0 & 0.0 & 0 & 0.0 & 0 & 0.0 & 0 & 0.0 & 0 & 0.0 & 0 & 0.0 \\
\hline ASTSCA & 0 & 0.0 & 0 & 0.0 & 0 & 0.0 & 0 & 0.0 & 0 & 0.0 & 0 & 0.0 & 0 & 0.0 & 0 & 0.0 & 0 & 0.0 & 0 & 0.0 \\
\hline BALSAG & 1 & 1.7 & 1 & 11.7 & 0 & 0.0 & 0 & 0.0 & 0.25 & 0.7 & 0.25 & 3.2 & 0 & 0.0 & 0 & 0.0 & 0.28 & 1.2 & 0.16 & 4.0 \\
\hline BESWYO & 0 & 0.0 & 0 & 0.0 & 0 & 0.0 & 0 & 0.0 & 0 & 0.0 & 0 & 0.0 & 0 & 0.0 & 0 & 0.0 & 0.28 & 0.4 & 0 & 0.0 \\
\hline BOIGLA & 0 & 0.0 & 0 & 0.0 & 0 & 0.0 & 0 & 0.0 & 0.12 & 0.6 & 0.12 & 0.1 & 1 & 0.1 & 0 & 0.0 & 0 & 0.0 & 0 & 0.0 \\
\hline BUPAME & 0 & 0.0 & 0 & 0.0 & 0 & 0.0 & 0 & 0.0 & 0 & 0.0 & 0 & 0.0 & 0 & 0.0 & 0 & 0.0 & 0 & 0.0 & 0 & 0.0 \\
\hline CALEUR & 0 & 0.0 & 0 & 0.0 & 0 & 0.0 & 0 & 0.0 & 0 & 0.0 & 0 & 0.0 & 0 & 0.0 & 0 & 0.0 & 0.14 & 0.3 & 0.16 & 0.4 \\
\hline CAMMIC & 0 & 0.0 & 0 & 0.0 & 0 & 0.0 & 0 & 0.0 & 0.25 & 0.5 & 0.12 & 0.1 & 0 & 0.0 & 0 & 0.0 & 0 & 0.0 & 0 & 0.0 \\
\hline CAM ROT & 0 & 0.0 & 0 & 0.0 & 0 & 0.0 & 0 & 0.0 & 0.12 & 0.3 & 0.12 & 0.6 & 0 & 0.0 & 0 & 0.0 & 0 & 0.0 & 0 & 0.0 \\
\hline CANUNI & 0 & 0.0 & 0 & 0.0 & 0 & 0.0 & 0 & 0.0 & 0 & 0.0 & 0 & 0.0 & 0 & 0.0 & 0 & 0.0 & 0 & 0.0 & 0 & 0.0 \\
\hline CASANG & 0 & 0.0 & 0 & 0.0 & 0 & 0.0 & 0 & 0.0 & 0 & 0.0 & 0 & 0.0 & 0 & 0.0 & 0 & 0.0 & 0 & 0.0 & 01 & 0.0 \\
\hline CASPAL & 0 & 0.0 & 0 & 0.0 & 0 & 0.0 & 0 & 0.0 & 0.12 & 0.1 & 0.37 & 0.2 & 0 & 0.0 & 0 & 0.0 & 0 & 0.0 & 0.5 & 0.1 \\
\hline CASSTR & 0 & 0.0 & 0 & 0.0 & 0 & 0.0 & 0 & 0.0 & 0 & 0.0 & 0 & 0.0 & 0 & 0.0 & 0 & 0.0 & 0 & 0.0 & 0 & 0.0 \\
\hline CASTIL & 0 & 0.0 & 0 & 0.0 & 0 & 0.0 & 0 & 0.0 & 0.12 & 0.2 & 0 & 0.0 & 0 & 0.0 & 0 & 0.0 & 0 & 0.0 & 0 & 0.0 \\
\hline CERARV & 0 & 0.0 & 0 & 0.0 & 0 & 0.0 & 0 & 0.0 & 0 & 0.0 & 0.25 & 2.1 & 0 & 0.0 & 0 & 0.0 & 0.28 & 0.6 & 0 & 0.0 \\
\hline CHADOU & 0 & 0.0 & 0 & 0.0 & 0 & 0.0 & 0 & 0.0 & 0 & 0.0 & 0 & 0.0 & 0 & 0.0 & 0 & 0.0 & 0 & 0.0 & 0 & 0.0 \\
\hline CHEALB & 0 & 0.0 & 0 & 0.0 & 0.33 & 0.1 & 0.33 & 0.4 & 0 & 0.0 & 0 & 0.0 & 0 & 0.0 & 0 & 0.0 & 0 & 0.0 & 0 & 0.0 \\
\hline CHEFRE & 1 & 0.5 & 1 & 0.5 & 0.33 & 0.1 & 0.33 & 0.1 & 0.37 & 0.1 & 0.12 & 0.1 & 0 & 0.0 & 0 & 0.0 & 0.14 & 0.1 & 0 & 0.0 \\
\hline CHELEP & 0 & 0.0 & 0 & 0.0 & 0.66 & 0.1 & 0.66 & 0.2 & 0 & 0.0 & 0 & 0.0 & 0 & 0.0 & 0 & 0.0 & 0 & 0.0 & 0 & 0.0 \\
\hline CHENOP & 0 & 0.0 & 0 & 0.0 & 0 & 0.0 & 0 & 0.0 & 0 & 0.0 & 0 & 0.0 & 0 & 0.0 & 0 & 0.0 & 0 & 0.0 & 0 & 0.0 \\
\hline CIRSCA & 0 & 0.0 & 0 & 0.0 & 0 & 0.0 & 0 & 0.0 & 0 & 0.0 & 0 & 0.0 & 0 & 0.0 & 0 & 0.0 & 0.14 & 0.3 & 0.16 & 0.4 \\
\hline CIRSIU & 0 & 0.0 & 0 & 0.0 & 0 & 0.0 & 0 & 0.0 & 0 & 0.0 & 0 & 0.0 & 0 & 0.0 & 0 & 0.0 & 0 & 0.0 & 0 & 0.0 \\
\hline CLEHIR & 0 & 0.0 & 0 & 0.0 & 0 & 0.0 & 0 & 0.0 & 0 & 0.0 & 0 & 0.0 & 0 & 0.0 & 0 & 0.0 & 0.14 & 0.1 & 0 & 0.0 \\
\hline COLLIN & 0 & 0.0 & 0 & 0.0 & 0 & 0.0 & 0 & 0.0 & 0.5 & 1.6 & 0.37 & 1.7 & 0 & 0.0 & 0 & 0.0 & 0.42 & 0.7 & 0.5 & 2.7 \\
\hline COLPAR & 0 & 0.0 & 0 & 0.0 & 0 & 0.0 & 0 & 0.0 & 0.62 & 0.3 & 0.37 & 0.3 & 0 & 0.0 & 0 & 0.0 & 0.28 & 0.3 & 0.33 & 0.4 \\
\hline CORRAM & 0 & 0.0 & 0 & 0.0 & 0 & 0.0 & 0.33 & 0.1 & 0 & 0.0 & 0 & 0.0 & 0 & 0.0 & 0 & 0.0 & 0 & 0.0 & 0 & 0.0 \\
\hline CREACU & 0 & 0.0 & 0 & 0.0 & 0 & 0.0 & 0 & 0.0 & 0 & 0.0 & 0 & 0.0 & 0 & 0.0 & 0 & 0.0 & 0.14 & 0.9 & 0 & 0.0 \\
\hline CREATR & 0 & 0.0 & 0 & 0.0 & 0 & 0.0 & 0 & 0.0 & 0 & 0.0 & 0 & 0.0 & 0 & 0.0 & 0 & 0.0 & 0 & 0.0 & 0.16 & 2.8 \\
\hline
\end{tabular}




\begin{tabular}{|c|c|c|c|c|c|c|c|c|c|c|c|c|c|c|c|c|c|c|c|c|}
\hline \multirow{2}{*}{$\frac{\text { SPECIES }}{\text { Forbs }}$} & \multicolumn{2}{|c|}{$\begin{array}{c}\text { ARTTST/ } \\
\text { HESCOM-B } \\
n=1 \\
\end{array}$} & \multicolumn{2}{|c|}{$\begin{array}{c}\text { ARTTST/ } \\
\text { HESCOM-C } \\
n=1 \\
\end{array}$} & \multicolumn{2}{|c|}{$\begin{array}{c}\text { ARTTST/ } \\
\text { PASSMI-B } \\
n=3\end{array}$} & \multicolumn{2}{|c|}{$\begin{array}{c}\text { ARTGST/ } \\
\text { PASSMI-C } \\
n=3\end{array}$} & $\begin{array}{r}\text { ARTTSV } \\
\text { ACHC } \\
\mathrm{n}\end{array}$ & $\begin{array}{l}\text { EESIDA- } \\
\text { CC-B } \\
8\end{array}$ & $\begin{array}{r}\text { ARTTSV } \\
\mathrm{ACHC} \\
\mathrm{n}= \\
\end{array}$ & $\begin{array}{l}\text { ESIDA- } \\
\mathrm{CC}-\mathrm{C} \\
3\end{array}$ & $\begin{array}{r}\text { ARTTSI } \\
\text { A-CAF } \\
n=\end{array}$ & $\begin{array}{l}/ / F E S I D \\
\text { FIL-B } \\
1 \\
\end{array}$ & $\begin{array}{r}\text { ARTTSV } \\
\text { A-CAF } \\
n= \\
\end{array}$ & $\begin{array}{l}\text { /FESID } \\
\text { FIL-C } \\
1 \\
\end{array}$ & $\begin{array}{r}\text { ARTTSV } \\
\text { A-GER } \\
n=\end{array}$ & $\begin{array}{l}\text { /FESID } \\
\text { VIS-B } \\
7 \\
\end{array}$ & $\begin{array}{r}\text { ARTTSV } \\
\text { A-GER } \\
n=\end{array}$ & $\begin{array}{l}\text { /FESID } \\
\text { VIS-C } \\
6 \\
\end{array}$ \\
\hline & CON & $\mathrm{cov}$ & CON & $\mathrm{cov}$ & $\mathrm{CON}$ & $\mathrm{cov}$ & CON & $\mathrm{cov}$ & CON & cov & $\mathrm{CON}$ & $\mathrm{cov}$ & CON & cov & CON & cov & $\mathrm{CON}$ & $\mathrm{cov}$ & CON & $\mathrm{cov}$ \\
\hline CREM OD & 0 & 0.0 & 0 & 0.0 & 0 & 0.0 & 0 & 0.0 & 0 & 0.0 & 0 & 0.0 & 0 & 0.0 & 0 & 0.0 & 0 & 0.0 & 0 & 0.0 \\
\hline CREPIS & 0 & 0.0 & 0 & 0.0 & 0 & 0.0 & 0 & 0.0 & 0 & 0.0 & 0 & 0.0 & 0 & 0.0 & 0 & 0.0 & 0 & 0.0 & 0.16 & 0.1 \\
\hline CRYPTA & 0 & 0.0 & 0 & 0.0 & 0 & 0.0 & 0 & 0.0 & 0.12 & 0.4 & 0 & 0.0 & 0 & 0.0 & 0 & 0.0 & 0 & 0.0 & 0 & 0.0 \\
\hline CYMBIP & 0 & 0.0 & 0 & 0.0 & 0 & 0.0 & 0 & 0.0 & 0 & 0.0 & 0 & 0.0 & 0 & 0.0 & 0 & 0.0 & 0 & 0.0 & 0 & 0.0 \\
\hline CYMPIP & 0 & 0.0 & 0 & 0.0 & 0 & 0.0 & 0 & 0.0 & 0 & 0.0 & 0 & 0.0 & 0 & 0.0 & 0 & 0.0 & 0 & 0.0 & 0 & 0.0 \\
\hline CYNOFF & 0 & 0.0 & 0 & 0.0 & 0 & 0.0 & 0 & 0.0 & 0 & 0.0 & 0 & 0.0 & 0 & 0.0 & 0 & 0.0 & 0 & 0.0 & 0 & 0.0 \\
\hline CYSFRA & 0 & 0.0 & 0 & 0.0 & 0 & 0.0 & 0 & 0.0 & 0 & 0.0 & 0 & 0.0 & 0 & 0.0 & 0 & 0.0 & 0 & 0.0 & 0 & 0.0 \\
\hline DELBIC & 0 & 0.0 & 0 & 0.0 & 0 & 0.0 & 0 & 0.0 & 0.25 & 0.5 & 0.5 & 0.2 & 0 & 0.0 & 0 & 0.0 & 0.42 & 0.3 & 0.5 & 0.2 \\
\hline DESRIC & 0 & 0.0 & 0 & 0.0 & 0.33 & 0.1 & 0.33 & 0.2 & 0 & 0.0 & 0 & 0.0 & 0 & 0.0 & 0 & 0.0 & 0 & 0.0 & 0 & 0.0 \\
\hline DESSOP & 0 & 0.0 & 0 & 0.0 & 0.33 & 0.1 & 0.33 & 0.1 & 0.25 & 0.5 & 0 & 0.0 & 0 & 0.0 & 0 & 0.0 & 0 & 0.0 & 0 & 0.0 \\
\hline DODCON & 0 & 0.0 & 0 & 0.0 & 0 & 0.0 & 0 & 0.0 & 0.12 & 0.1 & 0.37 & 0.1 & 0 & 0.0 & 0 & 0.0 & 0.42 & 0.4 & 0.16 & 0.3 \\
\hline DOUM ON & 0 & 0.0 & 0 & 0.0 & 0 & 0.0 & 0 & 0.0 & 0 & 0.0 & 0 & 0.0 & 0 & 0.0 & 0 & 0.0 & 0 & 0.0 & 0 & 0.0 \\
\hline DRABAX & 0 & 0.0 & 0 & 0.0 & 0 & 0.0 & 0.33 & 0.1 & 0 & 0.0 & 0.12 & 1.0 & 0 & 0.0 & 0 & 0.0 & 0 & 0.0 & 0 & 0.0 \\
\hline DRANEM & 0 & 0.0 & 0 & 0.0 & 0 & 0.0 & 0.33 & 0.1 & 0.5 & 0.2 & 0.37 & 0.1 & 0 & 0.0 & 0 & 0.0 & 0.14 & 0.1 & 0 & 0.0 \\
\hline DRASTE & 0 & 0.0 & 0 & 0.0 & 0 & 0.0 & 0 & 0.0 & 0 & 0.0 & 0 & 0.0 & 0 & 0.0 & 0 & 0.0 & 0 & 0.0 & 0 & 0.0 \\
\hline EPIPAN & 0 & 0.0 & 0 & 0.0 & 0 & 0.0 & 0 & 0.0 & 0 & 0.0 & 0 & 0.0 & 0 & 0.0 & 0 & 0.0 & 0.14 & 0.2 & 0.16 & 0.1 \\
\hline ERICES & 0 & 0.0 & 0 & 0.0 & 0 & 0.0 & 0.33 & 0.1 & 0 & 0.0 & 0 & 0.0 & 0 & 0.0 & 0 & 0.0 & 0 & 0.0 & 0 & 0.0 \\
\hline ERICOM & 0 & 0.0 & 0 & 0.0 & 0 & 0.0 & 0 & 0.0 & 0.12 & 0.4 & 0 & 0.0 & 0 & 0.0 & 1 & 0.1 & 0 & 0.0 & 0 & 0.0 \\
\hline ERICOR & 0 & 0.0 & 0 & 0.0 & 0 & 0.0 & 0 & 0.0 & 0.75 & 4.7 & 0.75 & 0.6 & 0 & 0.0 & 0 & 0.0 & 0.42 & 3.2 & 0.66 & 2.5 \\
\hline ERIFLA & 0 & 0.0 & 0 & 0.0 & 0 & 0.0 & 0 & 0.0 & 0 & 0.0 & 0 & 0.0 & 0 & 0.0 & 0 & 0.0 & 0.14 & 1.0 & 0 & 0.0 \\
\hline ERIGER & 0 & 0.0 & 0 & 0.0 & 0 & 0.0 & 0 & 0.0 & 0 & 0.0 & 0 & 0.0 & 0 & 0.0 & 0 & 0.0 & 0 & 0.0 & 0 & 0.0 \\
\hline ERIHER & 0 & 0.0 & 0 & 0.0 & 0 & 0.0 & 0 & 0.0 & 0 & 0.0 & 0.12 & 1.9 & 0 & 0.0 & 0 & 0.0 & 0.14 & 7.7 & 0.33 & 0.7 \\
\hline ERILIN & 0 & 0.0 & 0 & 0.0 & 0 & 0.0 & 0 & 0.0 & 0 & 0.0 & 0 & 0.0 & 0 & 0.0 & 0 & 0.0 & 0 & 0.0 & 0 & 0.0 \\
\hline ERIM IC & 0 & 0.0 & 0 & 0.0 & 0 & 0.0 & 0 & 0.0 & 0 & 0.0 & 0 & 0.0 & 0 & 0.0 & 0 & 0.0 & 0 & 0.0 & 0 & 0.0 \\
\hline ERIOVA & 0 & 0.0 & 0 & 0.0 & 0 & 0.0 & 0 & 0.0 & 0 & 0.0 & 0 & 0.0 & 0 & 0.0 & 0 & 0.0 & 0 & 0.0 & 0 & 0.0 \\
\hline ERIPUM & 0 & 0.0 & 0 & 0.0 & 0 & 0.0 & 0 & 0.0 & 0.12 & 0.1 & 0 & 0.0 & 0 & 0.0 & 0 & 0.0 & 0 & 0.0 & 0 & 0.0 \\
\hline ERISPE & 0 & 0.0 & 0 & 0.0 & 0 & 0.0 & 0 & 0.0 & 0.12 & 0.1 & 0 & 0.0 & 0 & 0.0 & 0 & 0.0 & 0 & 0.0 & 0.16 & 0.7 \\
\hline ERITWE & 0 & 0.0 & 0 & 0.0 & 0 & 0.0 & 0 & 0.0 & 0 & 0.0 & 0 & 0.0 & 0 & 0.0 & 0 & 0.0 & 0 & 0.0 & 0 & 0.0 \\
\hline ERIUMB & 1 & 0.1 & 1 & 0.1 & 0 & 0.0 & 0 & 0.0 & 0.37 & 0.9 & 0.62 & 2.8 & 1 & 0.3 & 1 & 0.7 & 0.85 & 1.7 & 1 & 3.1 \\
\hline ERYCHE & 0 & 0.0 & 0 & 0.0 & 0 & 0.0 & 0 & 0.0 & 0 & 0.0 & 0 & 0.0 & 0 & 0.0 & 0 & 0.0 & 0.14 & 0.1 & 0 & 0.0 \\
\hline ERYINC & 0 & 0.0 & 0 & 0.0 & 0 & 0.0 & 0 & 0.0 & 0 & 0.0 & 0 & 0.0 & 0 & 0.0 & 0 & 0.0 & 0.14 & 0.1 & 0 & 0.0 \\
\hline FRASPE & 0 & 0.0 & 0 & 0.0 & 0 & 0.0 & 0 & 0.0 & 0 & 0.0 & 0 & 0.0 & 0 & 0.0 & 0 & 0.0 & 0 & 0.0 & 0 & 0.0 \\
\hline FRAVES & 0 & 0.0 & 0 & 0.0 & 0 & 0.0 & 0 & 0.0 & 0 & 0.0 & 0 & 0.0 & 0 & 0.0 & 0 & 0.0 & 0 & 0.0 & 0.16 & 0.3 \\
\hline FRIPUD & 0 & 0.0 & 0 & 0.0 & 0 & 0.0 & 0 & 0.0 & 0 & 0.0 & 0 & 0.0 & 0 & 0.0 & 0 & 0.0 & 0 & 0.0 & 0 & 0.0 \\
\hline GALBIF & 0 & 0.0 & 0 & 0.0 & 0 & 0.0 & 0 & 0.0 & 0 & 0.0 & 0 & 0.0 & 0 & 0.0 & 0 & 0.0 & 0.14 & 0.1 & 0.16 & 0.1 \\
\hline GENAFF & 0 & 0.0 & 0 & 0.0 & 0 & 0.0 & 0 & 0.0 & 0 & 0.0 & 0 & 0.0 & 0 & 0.0 & 0 & 0.0 & 0 & 0.0 & 0.16 & 0.1 \\
\hline GERRIC & 0 & 0.0 & 0 & 0.0 & 0 & 0.0 & 0 & 0.0 & 0 & 0.0 & 0 & 0.0 & 0 & 0.0 & 0 & 0.0 & 0.14 & 1.3 & 0 & 0.0 \\
\hline GERVIS & 0 & 0.0 & 0 & 0.0 & 0 & 0.0 & 0 & 0.0 & 0.25 & 0.7 & 0.25 & 0.3 & 0 & 0.0 & 0 & 0.0 & 0.42 & 6.1 & 0.5 & 6.9 \\
\hline GEUTRI & 0 & 0.0 & 0 & 0.0 & 0 & 0.0 & 0 & 0.0 & 0.12 & 1.3 & 0.5 & 0.5 & 0 & 0.0 & 0 & 0.0 & 0.57 & 1.9 & 0.5 & 1.0 \\
\hline GILTER & 0 & 0.0 & 0 & 0.0 & 0 & 0.0 & 0 & 0.0 & 0 & 0.0 & 0 & 0.0 & 0 & 0.0 & 0 & 0.0 & 0 & 0.0 & 0 & 0.0 \\
\hline HACMIC & 0 & 0.0 & 0 & 0.0 & 0 & 0.0 & 0 & 0.0 & 0 & 0.0 & 0.12 & 0.6 & 0 & 0.0 & 0 & 0.0 & 0 & 0.0 & 0 & 0.0 \\
\hline HACPAT & 0 & 0.0 & 0 & 0.0 & 0 & 0.0 & 0 & 0.0 & 0 & 0.0 & 0.12 & 0.1 & 0 & 0.0 & 0 & 0.0 & 0 & 0.0 & 0 & 0.0 \\
\hline HAPACA & 0 & 0.0 & 0 & 0.0 & 0 & 0.0 & 0 & 0.0 & 0 & 0.0 & 0 & 0.0 & 0 & 0.0 & 0 & 0.0 & 0 & 0.0 & 0 & 0.0 \\
\hline HAPINT & 0 & 0.0 & 0 & 0.0 & 0 & 0.0 & 0 & 0.0 & 0 & 0.0 & 0 & 0.0 & 0 & 0.0 & 1 & 0.2 & 0 & 0.0 & 0 & 0.0 \\
\hline HAPUNI & 0 & 0.0 & 0 & 0.0 & 0 & 0.0 & 0 & 0.0 & 0.12 & 0.3 & 0 & 0.0 & 0 & 0.0 & 0 & 0.0 & 0 & 0.0 & 0 & 0.0 \\
\hline HEDHIS & 0 & 0.0 & 0 & 0.0 & 0 & 0.0 & 0 & 0.0 & 0 & 0.0 & 0 & 0.0 & 0 & 0.0 & 0 & 0.0 & 0 & 0.0 & 0.16 & 0.1 \\
\hline HELUNI & 0 & 0.0 & 0 & 0.0 & 0 & 0.0 & 0 & 0.0 & 0 & 0.0 & 0.25 & 1.9 & 0 & 0.0 & 0 & 0.0 & 0.28 & 7.2 & 0.5 & 2.9 \\
\hline HETVIL & 0 & 0.0 & 0 & 0.0 & 0 & 0.0 & 0 & 0.0 & 0 & 0.0 & 0 & 0.0 & 0 & 0.0 & 0 & 0.0 & 0 & 0.0 & 0 & 0.0 \\
\hline HEUPAR & 0 & 0.0 & 0 & 0.0 & 0 & 0.0 & 0 & 0.0 & 0 & 0.0 & 0 & 0.0 & 0 & 0.0 & 0 & 0.0 & 0.28 & 0.1 & 0 & 0.0 \\
\hline HIECYN & 0 & 0.0 & 0 & 0.0 & 0 & 0.0 & 0 & 0.0 & 0.12 & 1.4 & 0 & 0.0 & 0 & 0.0 & 0 & 0.0 & 0.14 & 3.3 & 0.16 & 0.3 \\
\hline HYDCAP & 0 & 0.0 & 0 & 0.0 & 0 & 0.0 & 0 & 0.0 & 0 & 0.0 & 0 & 0.0 & 0 & 0.0 & 0 & 0.0 & 0 & 0.0 & 0.16 & 0.1 \\
\hline IONALP & 0 & 0.0 & 0 & 0.0 & 0 & 0.0 & 0 & 0.0 & 0 & 0.0 & 0 & 0.0 & 0 & 0.0 & 0 & 0.0 & 0 & 0.0 & 0 & 0.0 \\
\hline KOCsco & 0 & 0.0 & 0 & 0.0 & 0.33 & 0.1 & 0 & 0.0 & 0 & 0.0 & 0 & 0.0 & 0 & 0.0 & 0 & 0.0 & 0 & 0.0 & 0 & 0.0 \\
\hline LAPRED & 0 & 0.0 & 0 & 0.0 & 0.66 & 0.4 & 0.66 & 0.2 & 0.37 & 0.2 & 0 & 0.0 & 0 & 0.0 & 0 & 0.0 & 0 & 0.0 & 0 & 0.0 \\
\hline LEPCAM & 0 & 0.0 & 0 & 0.0 & 0 & 0.0 & 0 & 0.0 & 0.12 & 0.2 & 0 & 0.0 & 0 & 0.0 & 0 & 0.0 & 0 & 0.0 & 0 & 0.0 \\
\hline LEPDEN & 0 & 0.0 & 0 & 0.0 & 0 & 0.0 & 0 & 0.0 & 0.12 & 0.1 & 0 & 0.0 & 0 & 0.0 & 0 & 0.0 & 0.14 & 0.1 & 0.16 & 0.1 \\
\hline LEPIDI & 0 & 0.0 & 0 & 0.0 & 0 & 0.0 & 0.33 & 0.1 & 0 & 0.0 & 0 & 0.0 & 0 & 0.0 & 0 & 0.0 & 0 & 0.0 & 0 & 0.0 \\
\hline LESALP & 0 & 0.0 & 0 & 0.0 & 0 & 0.0 & 0 & 0.0 & 0.12 & 0.1 & 0 & 0.0 & 0 & 0.0 & 0 & 0.0 & 0 & 0.0 & 0 & 0.0 \\
\hline LEWRED & 0 & 0.0 & 0 & 0.0 & 0 & 0.0 & 0 & 0.0 & 0 & 0.0 & 0 & 0.0 & 0 & 0.0 & 0 & 0.0 & 0 & 0.0 & 0 & 0.0 \\
\hline LINLEW & 0 & 0.0 & 0 & 0.0 & 0 & 0.0 & 0 & 0.0 & 0 & 0.0 & 0 & 0.0 & 0 & 0.0 & 0 & 0.0 & 0.14 & 0.1 & 0.16 & 0.1 \\
\hline LITINC & 0 & 0.0 & 0 & 0.0 & 0 & 0.0 & 0 & 0.0 & 0 & 0.0 & 0 & 0.0 & 0 & 0.0 & 0 & 0.0 & 0 & 0.0 & 0 & 0.0 \\
\hline LITPAR & 0 & 0.0 & 0 & 0.0 & 0 & 0.0 & 0 & 0.0 & 0 & 0.0 & 0 & 0.0 & 0 & 0.0 & 0 & 0.0 & 0 & 0.0 & 0 & 0.0 \\
\hline LITRUD & 0 & 0.0 & 0 & 0.0 & 0 & 0.0 & 0 & 0.0 & 0.25 & 1.3 & 0.37 & 1.6 & 0 & 0.0 & 0 & 0.0 & 0 & 0.0 & 0.33 & 0.1 \\
\hline LOMCOU & 0 & 0.0 & 0 & 0.0 & 0 & 0.0 & 0 & 0.0 & 0.12 & 0.1 & 0 & 0.0 & 0 & 0.0 & 0 & 0.0 & 0 & 0.0 & 0 & 0.0 \\
\hline LOMFOE & 0 & 0.0 & 0 & 0.0 & 0 & 0.0 & 0 & 0.0 & 0 & 0.0 & 0 & 0.0 & 0 & 0.0 & 0 & 0.0 & 0 & 0.0 & 0 & 0.0 \\
\hline LOMTRI & 0 & 0.0 & 0 & 0.0 & 0 & 0.0 & 0 & 0.0 & 0.5 & 0.3 & 0.5 & 0.2 & 0 & 0.0 & 0 & 0.0 & 0.42 & 0.6 & 0.5 & 0.1 \\
\hline
\end{tabular}

Appendix C - 3 


\begin{tabular}{|c|c|c|c|c|c|c|c|c|c|c|c|c|c|c|c|c|c|c|c|c|}
\hline \multirow{2}{*}{$\frac{\text { SPECIES }}{\text { Forbs }}$} & \multicolumn{2}{|c|}{$\begin{array}{c}\text { ARTTST/ } \\
\text { HESCOM-B } \\
n=1\end{array}$} & \multicolumn{2}{|c|}{$\begin{array}{c}\text { ARTTST/ } \\
\text { HESCOM-C } \\
n=1\end{array}$} & \multicolumn{2}{|c|}{$\begin{array}{c}\text { ARTTST/ } \\
\text { PASSMI-B } \\
n=3\end{array}$} & \multicolumn{2}{|c|}{$\begin{array}{c}\text { ARTGST/ } \\
\text { PASSMI-C } \\
n=3\end{array}$} & \multicolumn{2}{|c|}{$\begin{array}{c}\text { ARTTSV/FESIDA- } \\
\text { ACHOCC-B } \\
n=8\end{array}$} & \multicolumn{2}{|c|}{$\begin{array}{c}\text { ARTTSV/FESIDA- } \\
\text { ACHOCC-C } \\
n=8\end{array}$} & \multicolumn{2}{|c|}{$\begin{array}{c}\text { ARTTSV/FESID } \\
\text { A-CARFIL-B } \\
n=1 \\
\end{array}$} & $\begin{array}{r}\text { ARTTSV } \\
\text { A-CAF } \\
\mathrm{n}=\end{array}$ & $\begin{array}{l}\text { /FESID } \\
\text { FFL-C } \\
1 \\
\end{array}$ & $\begin{array}{r}\text { ARTTSV } \\
\text { A-GER } \\
n=\end{array}$ & $\begin{array}{l}\text { /FESID } \\
\text { VIS-B } \\
7\end{array}$ & $\begin{array}{r}\text { ARTTSV } \\
\text { A-GER } \\
n=\end{array}$ & $\begin{array}{l}\text { /FESID } \\
\text { VIS-C } \\
6 \\
\end{array}$ \\
\hline & $\mathrm{CON}$ & $\mathrm{cov}$ & CON & $\mathrm{cov}$ & $\mathrm{CON}$ & $\mathrm{cov}$ & CON & $\mathrm{cov}$ & $\mathrm{CON}$ & $\mathrm{cov}$ & CON & $\mathrm{cov}$ & CON & $\mathrm{cov}$ & CON & $\mathrm{cov}$ & $\mathrm{CON}$ & $\mathrm{cov}$ & CON & $\mathrm{cov}$ \\
\hline LUPARG & 0 & 0.0 & 1 & 2.0 & 0 & 0.0 & 0 & 0.0 & 0.12 & 3.0 & 0 & 0.0 & 0 & 0.0 & 0 & 0.0 & 0 & 0.0 & 0 & 0.0 \\
\hline LUPINU & 0 & 0.0 & 0 & 0.0 & 0 & 0.0 & 0 & 0.0 & 0.12 & 2.6 & 0 & 0.0 & 0 & 0.0 & 0 & 0.0 & 0 & 0.0 & 0 & 0.0 \\
\hline LUPLEU & 0 & 0.0 & 0 & 0.0 & 0 & 0.0 & 0 & 0.0 & 0 & 0.0 & 0 & 0.0 & 1 & 2.9 & 1 & 0.2 & 0 & 0.0 & 0 & 0.0 \\
\hline LUPSER & 1 & 0.2 & 1 & 2.7 & 0 & 0.0 & 0 & 0.0 & 0.74 & 9.6 & 0.87 & 6.3 & 0 & 0.0 & 0 & 0.0 & 0.85 & 10.5 & 0.83 & 8.3 \\
\hline LUPWYE & 0 & 0.0 & 0 & 0.0 & 0 & 0.0 & 0 & 0.0 & 0.12 & 11.3 & 0.12 & 0.9 & 0 & 0.0 & 0 & 0.0 & 0.14 & 3.8 & 0.16 & 7.4 \\
\hline MACCAN & 0 & 0.0 & 0 & 0.0 & 0 & 0.0 & 0 & 0.0 & 0 & 0.0 & 0 & 0.0 & 0 & 0.0 & 0 & 0.0 & 0 & 0.0 & 0 & 0.0 \\
\hline MACHAE & 0 & 0.0 & 0 & 0.0 & 0 & 0.0 & 0 & 0.0 & 0.12 & 0.1 & 0 & 0.0 & 0 & 0.0 & 0 & 0.0 & 0 & 0.0 & 0 & 0.0 \\
\hline MEROBL & 0 & 0.0 & 0 & 0.0 & 0 & 0.0 & 0 & 0.0 & 0.62 & 0.5 & 0.75 & 0.7 & 1 & 0.2 & 0 & 0.0 & 0.42 & 0.5 & 0.5 & 0.6 \\
\hline MICGRA & 0 & 0.0 & 0 & 0.0 & 0 & 0.0 & 0 & 0.0 & 0.12 & 0.2 & 0.25 & 0.2 & 0 & 0.0 & 0 & 0.0 & 0 & 0.0 & 0.16 & 0.1 \\
\hline MICNUT & 0 & 0.0 & 0 & 0.0 & 0 & 0.0 & 0 & 0.0 & 0.12 & 0.1 & 0.12 & 0.2 & 0 & 0.0 & 0 & 0.0 & 0.14 & 0.8 & 0.16 & 0.3 \\
\hline MUSDIV & 0 & 0.0 & 0 & 0.0 & 0 & 0.0 & 0 & 0.0 & 0 & 0.0 & 0 & 0.0 & 0 & 0.0 & 0 & 0.0 & 0 & 0.0 & 0 & 0.0 \\
\hline MYOSYL & 0 & 0.0 & 0 & 0.0 & 0 & 0.0 & 0 & 0.0 & 0 & 0.0 & 0 & 0.0 & 0 & 0.0 & 0 & 0.0 & 0 & 0.0 & 0 & 0.0 \\
\hline NEMBRE & 0 & 0.0 & 0 & 0.0 & 0 & 0.0 & 0 & 0.0 & 0.12 & 0.1 & 0.12 & 0.5 & 0 & 0.0 & 0 & 0.0 & 0.14 & 0.4 & 0.33 & 0.7 \\
\hline NOTTRO & 0 & 0.0 & 0 & 0.0 & 0 & 0.0 & 0 & 0.0 & 0.37 & 0.2 & 0.25 & 0.1 & 0 & 0.0 & 0 & 0.0 & 0 & 0.0 & 0.16 & 0.1 \\
\hline OENOTH & 0 & 0.0 & 0 & 0.0 & 0 & 0.0 & 0 & 0.0 & 0 & 0.0 & 0 & 0.0 & 0 & 0.0 & 0 & 0.0 & 0.14 & 1.5 & 0 & 0.0 \\
\hline OXYLAG & 0 & 0.0 & 0 & 0.0 & 0 & 0.0 & 0 & 0.0 & 0 & 0.0 & 0 & 0.0 & 0 & 0.0 & 0 & 0.0 & 0 & 0.0 & 0 & 0.0 \\
\hline OXYSER & 0 & 0.0 & 0 & 0.0 & 0 & 0.0 & 0 & 0.0 & 0 & 0.0 & 0 & 0.0 & 0 & 0.0 & 0 & 0.0 & 0 & 0.0 & 0 & 0.0 \\
\hline OXYvIS & 0 & 0.0 & 0 & 0.0 & 0 & 0.0 & 0 & 0.0 & 0 & 0.0 & 0 & 0.0 & 0 & 0.0 & 0 & 0.0 & 0 & 0.0 & 0 & 0.0 \\
\hline PEDPAR & 0 & 0.0 & 0 & 0.0 & 0 & 0.0 & 0 & 0.0 & 0 & 0.0 & 0 & 0.0 & 0 & 0.0 & 0 & 0.0 & 0 & 0.0 & 0 & 0.0 \\
\hline PEDSIM & 0 & 0.0 & 0 & 0.0 & 0 & 0.0 & 0 & 0.0 & 0 & 0.0 & 0 & 0.0 & 0 & 0.0 & 0 & 0.0 & 0 & 0.0 & 0 & 0.0 \\
\hline PENARI & 0 & 0.0 & 0 & 0.0 & 0 & 0.0 & 0 & 0.0 & 0 & 0.0 & 0 & 0.0 & 0 & 0.0 & 0 & 0.0 & 0 & 0.0 & 0 & 0.0 \\
\hline PENERI & 0 & 0.0 & 0 & 0.0 & 0 & 0.0 & 0 & 0.0 & 0 & 0.0 & 0 & 0.0 & 0 & 0.0 & 0 & 0.0 & 0 & 0.0 & 0 & 0.0 \\
\hline PENPRO & 0 & 0.0 & 0 & 0.0 & 0 & 0.0 & 0 & 0.0 & 0.12 & 0.1 & 0.12 & 0.3 & 0 & 0.0 & 0 & 0.0 & 0.42 & 1.9 & 0.33 & 2.6 \\
\hline PENRAD & 0 & 0.0 & 0 & 0.0 & 0 & 0.0 & 0 & 0.0 & 0 & 0.0 & 0 & 0.0 & 0 & 0.0 & 0 & 0.0 & 0.14 & 0.1 & 0.16 & 0.1 \\
\hline PERGAI & 0 & 0.0 & 0 & 0.0 & 0 & 0.0 & 0 & 0.0 & 0.12 & 0.1 & 0.12 & 0.1 & 0 & 0.0 & 0 & 0.0 & 0.14 & 0.9 & 0.5 & 0.3 \\
\hline PHAHAS & 0 & 0.0 & 1 & 1.1 & 0 & 0.0 & 0 & 0.0 & 0.12 & 0.1 & 0.12 & 0.1 & 0 & 0.0 & 0 & 0.0 & 0.14 & 0.1 & 0 & 0.0 \\
\hline PHALIN & 0 & 0.0 & 0 & 0.0 & 0 & 0.0 & 0 & 0.0 & 0 & 0.0 & 0 & 0.0 & 0 & 0.0 & 0 & 0.0 & 0 & 0.0 & 0 & 0.0 \\
\hline PHLCAE & 0 & 0.0 & 0 & 0.0 & 0 & 0.0 & 0 & 0.0 & 0 & 0.0 & 0 & 0.0 & 0 & 0.0 & 0 & 0.0 & 0.14 & 0.4 & 0 & 0.0 \\
\hline PHLHOO & $1)$ & 0.1 & 0 & 0.0 & 0 & 0.0 & 0.33 & 0.1 & 0 & 0.0 & 0 & 0.0 & 0 & 0.0 & 0 & 0.0 & 0.14 & 0.1 & 0.16 & 0.5 \\
\hline PHLLON & 1 & 0.1 & 0 & 0.0 & 0 & 0.0 & 0 & 0.0 & 1 & 1.7 & 1 & 0.9 & 0 & 0.0 & 0 & 0.0 & 0.71 & 1.2 & 0.5 & 0.3 \\
\hline PHLMUL & 0 & 0.0 & 0 & 0.0 & 0 & 0.0 & 0 & 0.0 & 0.12 & 0.1 & 0 & 0.0 & 0 & 0.0 & 0 & 0.0 & 0 & 0.0 & 0 & 0.0 \\
\hline PHLMUS & 0 & 0.0 & 0 & 0.0 & 0 & 0.0 & 0 & 0.0 & 0 & 0.0 & 0 & 0.0 & 0 & 0.0 & 0 & 0.0 & 0 & 0.0 & 0 & 0.0 \\
\hline POLDOU & 1 & 0.1 & 1 & 0.1 & 0 & 0.0 & 0 & 0.0 & 0.37 & 0.2 & 0.25 & 0.4 & 0 & 0.0 & 0 & 0.0 & 0.42 & 0.6 & 0.5 & 0.7 \\
\hline POTARG & 0 & 0.0 & 0 & 0.0 & 0 & 0.0 & 0 & 0.0 & 0 & 0.0 & 0 & 0.0 & 0 & 0.0 & 0 & 0.0 & 0.28 & 9.6 & 0.5 & 0.1 \\
\hline POTGLA & 0 & 0.0 & 0 & 0.0 & 0 & 0.0 & 0 & 0.0 & 0 & 0.0 & 0 & 0.0 & 0 & 0.0 & 0 & 0.0 & 0.14 & 0.4 & 0 & 0.0 \\
\hline POTGRA & 0 & 0.0 & 0 & 0.0 & 0 & 0.0 & 0 & 0.0 & 0 & 0.0 & 0.12 & 0.1 & 0 & 0.0 & 1 & 0.1 & 0.57 & 2.8 & 0.5 & 2.1 \\
\hline RANALI & 0 & 0.0 & 0 & 0.0 & 0 & 0.0 & 0 & 0.0 & 0 & 0.0 & 0 & 0.0 & 0 & 0.0 & 0 & 0.0 & 0.14 & 0.1 & 0 & 0.0 \\
\hline RANGLA & 0 & 0.0 & 0 & 0.0 & 0 & 0.0 & 0 & 0.0 & 0 & 0.0 & 0 & 0.0 & 0 & 0.0 & 0 & 0.0 & 0 & 0.0 & 0 & 0.0 \\
\hline RANUNC & 0 & 0.0 & 0 & 0.0 & 0 & 0.0 & 0 & 0.0 & 0 & 0.0 & 0 & 0.0 & 0 & 0.0 & 0 & 0.0 & 0 & 0.0 & 0 & 0.0 \\
\hline RUMPAU & 0 & 0.0 & 0 & 0.0 & 0 & 0.0 & 0 & 0.0 & 0 & 0.0 & 0.12 & 0.1 & 0 & 0.0 & 0 & 0.0 & 0 & 0.0 & 0 & 0.0 \\
\hline SCHLIN & 0 & 0.0 & 0 & 0.0 & 0 & 0.0 & 0.33 & 0.1 & 0 & 0.0 & 0 & 0.0 & 0 & 0.0 & 0 & 0.0 & 0 & 0.0 & 0 & 0.0 \\
\hline SEDLAN & 0 & 0.0 & 0 & 0.0 & 0 & 0.0 & 0 & 0.0 & 0 & 0.0 & 0 & 0.0 & 0 & 0.0 & 0 & 0.0 & 0.14 & 0.4 & 0.16 & 0.1 \\
\hline SELDEN & 0 & 0.0 & 0 & 0.0 & 0 & 0.0 & 0 & 0.0 & 0 & 0.0 & 0 & 0.0 & 0 & 0.0 & 0 & 0.0 & 0 & 0.0 & 0 & 0.0 \\
\hline SENCRA & 0 & 0.0 & 0 & 0.0 & 0 & 0.0 & 0 & 0.0 & 0 & 0.0 & 0 & 0.0 & 1 & 0.5 & 1 & 0.3 & 0.14 & 0.4 & 0.16 & 1.2 \\
\hline SENINT & 0 & 0.0 & 0 & 0.0 & 0 & 0.0 & 0 & 0.0 & 0.25 & 0.2 & 0.12 & 0.1 & 0 & 0.0 & 0 & 0.0 & 0.28 & 0.6 & 0.16 & 0.1 \\
\hline SILDOU & 0 & 0.0 & 0 & 0.0 & 0 & 0.0 & 0 & 0.0 & 0 & 0.0 & 0 & 0.0 & 0 & 0.0 & 0 & 0.0 & 0 & 0.0 & 0 & 0.0 \\
\hline SILDRU & 0 & 0.0 & 0 & 0.0 & 0 & 0.0 & 0 & 0.0 & 0.12 & 0.1 & 0.12 & 0.1 & 0 & 0.0 & 0 & 0.0 & 0.14 & 0.1 & 0.16 & 0.1 \\
\hline SISALT & 0 & 0.0 & 0 & 0.0 & 0.66 & 0.1 & 0 & 0.0 & 0.12 & 3.1 & 0.12 & 0.3 & 0 & 0.0 & 0 & 0.0 & 0 & 0.0 & 0 & 0.0 \\
\hline SOLIDA & 0 & 0.0 & 0 & 0.0 & 0 & 0.0 & 0 & 0.0 & 0 & 0.0 & 0 & 0.0 & 0 & 0.0 & 0 & 0.0 & 0 & 0.0 & 0 & 0.0 \\
\hline SOLMIS & 0 & 0.0 & 0 & 0.0 & 0 & 0.0 & 0 & 0.0 & 0 & 0.0 & 0.12 & 4.7 & 0 & 0.0 & 0 & 0.0 & 0 & 0.0 & 0.16 & 0.4 \\
\hline SOLMUL & 0 & 0.0 & 0 & 0.0 & 0 & 0.0 & 0 & 0.0 & 0 & 0.0 & 0 & 0.0 & 0 & 0.0 & 0 & 0.0 & 0.14 & 1.1 & 0.33 & 0.5 \\
\hline SPHCOC & 0 & 0.0 & 0 & 0.0 & 0 & 0.0 & 0 & 0.0 & 0 & 0.0 & 0 & 0.0 & 0 & 0.0 & 0 & 0.0 & 0 & 0.0 & 0 & 0.0 \\
\hline STERUN & 0 & 0.0 & 0 & 0.0 & 0 & 0.0 & 0 & 0.0 & 0 & 0.0 & 0 & 0.0 & 0 & 0.0 & 0 & 0.0 & 0 & 0.0 & 0 & 0.0 \\
\hline TARLAE & 0 & 0.0 & 0 & 0.0 & 0 & 0.0 & 0 & 0.0 & 0.12 & 0.5 & 0 & 0.0 & 0 & 0.0 & 0 & 0.0 & 0 & 0.0 & 0 & 0.0 \\
\hline TAROFF & 0 & 0.0 & 0 & 0.0 & 0.33 & 0.2 & 0.33 & 0.2 & 0.87 & 2.4 & 1 & 3.4 & 1 & 1.2 & 1. & 0.2 & 0.71 & 2.0 & 0.83 & 0.8 \\
\hline TRADUB & 0 & 0.0 & 0 & 0.0 & 0 & 0.0 & 0 & 0.0 & 0.25 & 0.3 & 0.25 & 0.1 & 0 & 0.0 & 0 & 0.0 & 0 & 0.0 & 0.33 & 0.1 \\
\hline TRILON & 0 & 0.0 & 0 & 0.0 & 0 & 0.0 & 0 & 0.0 & 0 & 0.0 & 0 & 0.0 & 0 & 0.0 & 0 & 0.0 & 0 & 0.0 & 0 & 0.0 \\
\hline VIONUT & 0 & 0.0 & 0 & 0.0 & 0 & 0.0 & 0 & 0.0 & 0.87 & 0.3 & 0.87 & 1.4 & 1 & 0.4 & 1 & 0.8 & 0.71 & 0.5 & 0.66 & 0.7 \\
\hline ZIGVEN & 0 & 0.0 & 0 & 0.0 & 0 & 0.0 & 0 & 0.0 & 0.25 & 0.5 & 0.37 & 0.9 & 0 & 0.0 & 0 & 0.0 & 0.14 & 0.2 & 0.5 & 0.1 \\
\hline
\end{tabular}




\begin{tabular}{|c|c|c|c|c|c|c|c|c|c|c|c|c|c|c|c|c|c|c|c|c|}
\hline \multirow{2}{*}{$\begin{array}{l}\text { SPECIES } \\
\text { Shrubs }\end{array}$} & \multicolumn{2}{|c|}{$\begin{array}{c}\text { ARTTSV/FESID } \\
\text { A-PASSMI-B } \\
n=3\end{array}$} & \multicolumn{2}{|c|}{$\begin{array}{c}\text { ARTTSV/FESID } \\
\text { A-PASSMI-C } \\
n=3\end{array}$} & \multicolumn{2}{|c|}{$\begin{array}{c}\text { ARTTSV/FESID } \\
\text { A-PSESPI-B } \\
n=10\end{array}$} & \multicolumn{2}{|c|}{$\begin{array}{c}\text { ARTTSV/FESID } \\
\text { A-PSESPI-C } \\
n=11\end{array}$} & \multicolumn{2}{|c|}{$\begin{array}{c}\text { ARTTSW/PSESPI- } \\
\text { PASSMI-B } \\
n=1\end{array}$} & \multicolumn{2}{|c|}{$\begin{array}{c}\text { ARTTSW/PSESPI- } \\
\text { PASSMI-C } \\
n=1\end{array}$} & \multicolumn{2}{|c|}{$\begin{array}{c}\text { ARTTSW/ } \\
\text { FESIDA-B } \\
n=3\end{array}$} & \multicolumn{2}{|c|}{$\begin{array}{c}\text { ARTTSW/ } \\
\text { FESIDA-C } \\
n=2\end{array}$} & \multicolumn{2}{|c|}{$\begin{array}{c}\text { ARTTSW/ } \\
\text { PSESPI-B } \\
\mathrm{n}=3\end{array}$} & \multicolumn{2}{|c|}{$\begin{array}{c}\text { ARTTSW/ } \\
\text { PSESPI-C } \\
n=3\end{array}$} \\
\hline & CON & cov & CON & cov & CON & $\mathrm{cov}$ & CON & cov & CON & cov & CON & cov & CON & cov & $\mathrm{CON}$ & cov & $\mathrm{CON}$ & $\mathrm{cov}$ & $\mathrm{CON}$ & cov \\
\hline ARTARB & 0 & 0.0 & 0 & 0.0 & 0 & 0.0 & 0 & 0.0 & 0 & 0.0 & 0 & 0.0 & 0.33 & 17.1 & 0 & 0.0 & 0 & 0.0 & 0 & 0.0 \\
\hline ARTFRI & 0.66 & 6.5 & 0.33 & 4.1 & 0.6 & 0.6 & 0.27 & 0.1 & 1 & 0.2 & & 0.1 & 0.65 & 0.4 & 0.5 & 0.1 & 1 & 4.3 & 1 & 1.8 \\
\hline ARTTRP & 0.33 & 8.1 & 0.33 & 3.1 & 0.2 & 6.5 & 0.09 & 0.3 & 0 & 0.0 & 1 & 0.2 & 0.33 & 20.6 & 0 & 0.0 & 0.33 & 0.7 & 0.66 & 4.2 \\
\hline ARTTST & 0 & 0.0 & 0 & 0.0 & 0 & 0.0 & 0 & 0.0 & 0 & 0.0 & 0 & 0.0 & 0 & 0.0 & 0 & 0.0 & 0 & 0.0 & 0 & 0.0 \\
\hline ARTTSV & 1 & 9.7 & 1 & 22.9 & 0.9 & 7.6 & 1 & 25.5 & 0 & 0.0 & 0 & 0.0 & 0.33 & 0.4 & 0.5 & 21.2 & 0 & 0.0 & 0 & 0.0 \\
\hline ARTTSW & 0.33 & 0.4 & 0 & 0.0 & 0 & 0.0 & 0 & 0.0 & 0 & 0.0 & 1 & 19.1 & 0.66 & 1.1 & 0.5 & 12.0 & 0.33 & 0.1 & 1 & 12.7 \\
\hline CHRNAU & 0.66 & 0.6 & 0.66 & 0.4 & 0.2 & 0.1 & 0.09 & 0.1 & 1 & 0.1 & 0 & 0.0 & 0.66 & 1.3 & 0.5 & 0.2 & 0.33 & 1.3 & 0.33 & 0.3 \\
\hline CHRVIS & 1 & 1.7 & 0.33 & 0.4 & 0.4 & 0.3 & 0.18 & 0.1 & & 0.1 & & 0.0 & 1 & 0.5 & 0.5 & 0.2 & 0.66 & 5.0 & 0.66 & 0.8 \\
\hline GUTSAR & 0 & 0.0 & 0 & 0.0 & 0 & 0.0 & 0 & 0.0 & 1 & 0.8 & & 1.0 & 0.33 & 1.8 & 0.5 & 0.1 & 0.66 & 4.0 & 0.66 & 0.7 \\
\hline JUNSCO & 0 & 0.0 & 0 & 0.0 & 0 & 0.0 & 0.18 & 1.8 & 0 & 0.0 & 0 & 0.0 & 0.33 & 0.3 & 0 & 0.0 & 0 & 0.0 & 0 & 0.0 \\
\hline KRALAN & 0 & 0.0 & 0 & 0.0 & 0 & 0.0 & 0 & 0.0 & 1 & 0.1 & 0 & 0.0 & 0 & 0.0 & 0 & 0.0 & 0.33 & 0.2 & 0 & 0.0 \\
\hline MAHREP & 0 & 0.0 & 0 & 0.0 & 0 & 0.0 & 0 & 0.0 & & 0.0 & & 0.6 & 0 & 0.0 & 0 & 0.0 & 0 & 0.0 & 0 & 0.0 \\
\hline OPUFRA & 0 & 0.0 & & 0.0 & 0 & & 0 & & & 0 & & & 0 & & 0 & & 0 & 0.0 & 0 & 0.0 \\
\hline OPUPOL & 0 & 0.0 & 0 & 0.0 & 0.1 & 0.1 & 0 & 0.0 & 0 & 0.0 & 0 & 0. & 0 & 0.0 & 0 & 0.0 & 0.66 & 1.1 & 1 & 2.2 \\
\hline SARVER & 0 & 0.0 & 0 & 0.0 & 0 & 0.0 & 0 & 0.0 & 0 & 0.0 & 0 & 0.0 & 0 & 0.0 & 0 & 0.0 & 0 & 0.0 & 0 & 0.0 \\
\hline SYMOCC & 0 & 0.0 & 0 & 0.0 & 0 & 0.0 & 0 & & 0 & 0.0 & & 0. & 0 & 0.0 & 0 & & 0 & 0.0 & 0 & 0.0 \\
\hline SYMORE & 0 & 0.0 & 0 & 0.0 & 0 & 0.0 & 0.09 & 0.6 & 0 & 0.0 & 0 & 0.0 & 0 & 0.0 & 0 & 0.0 & 0 & 0.0 & 0 & 0.0 \\
\hline TETCAN & 0.66 & 0.1 & 0 & 0.0 & 0.5 & 1.1 & 0.27 & 0.2 & 0 & 0.0 & 0 & 0.0 & 0.33 & 0.1 & 0 & 0.0 & 0.33 & 0.0 & 0 & 0.0 \\
\hline
\end{tabular}

\begin{tabular}{|c|c|c|c|c|c|c|c|c|c|c|c|c|c|c|c|c|c|c|c|c|}
\hline Graminoids & $\mathrm{CON}$ & $\mathrm{cov}$ & CON & $\mathrm{cov}$ & CON & $\mathrm{cov}$ & CON & $\mathrm{cov}$ & CON & cov & $\mathrm{CON}$ & $\mathrm{cov}$ & $\mathrm{CON}$ & $\mathrm{cov}$ & $\mathrm{CON}$ & $\mathrm{cov}$ & $\mathrm{CON}$ & $\mathrm{cov}$ & $\mathrm{CON}$ & cov \\
\hline ACHHYM & 0 & 0.0 & 0 & 0.0 & 0 & 0.0 & 0 & 0.0 & 0 & 0.0 & 0 & 0.0 & 0 & 0.0 & 0 & 0.0 & 0.33 & 0.4 & 0 & 0.0 \\
\hline ACHOCC & 0 & 0.0 & 0.33 & 0.1 & 0.3 & 3.4 & 0.45 & 2.8 & 0 & 0.0 & 0 & 0.0 & 0 & 0.0 & 0 & 0.0 & 0 & 0.0 & 0 & 0.0 \\
\hline ACHRIC & 0 & 0.0 & 0 & 0.0 & 0 & 0.0 & 0 & 0.0 & 0 & 0.0 & 0 & 0.0 & 0.33 & 1.6 & 0.5 & 3.0 & 0 & 0.0 & 0 & 0.0 \\
\hline AGRHUM & 0 & 0.0 & 0 & 0.0 & 0 & 0.0 & 0 & 0.0 & 0 & 0.0 & 0 & 0.0 & 0 & 0.0 & 0 & 0.0 & 0 & 0.0 & 0 & 0.0 \\
\hline BOUGRA & 0 & 0.0 & 0 & 0.0 & 0.1 & 0.4 & 0 & 0.0 & 0 & 0.0 & 0 & 0.0 & 0 & 0.0 & 0 & 0.0 & 0 & 0.0 & 0.33 & 0.3 \\
\hline BROANO & 0.33 & 0.3 & 0 & 0.0 & 0 & 0.0 & 0 & 0.0 & 0 & 0.0 & 0 & 0.0 & 0 & 0.0 & 0 & 0.0 & 0 & 0.0 & 0 & 0.0 \\
\hline BROCAR & 0 & 0.0 & 0.33 & 0.8 & 0 & 0.0 & 0 & 0.0 & 0 & 0.0 & 0 & 0.0 & 0 & 0.0 & 0 & 0.0 & 0 & 0.0 & 0 & 0.0 \\
\hline BROINE & 0 & 0.0 & 0 & 0.0 & 0 & 0.0 & 0 & 0.0 & 0 & 0.0 & 0 & 0.0 & 0 & 0.0 & 0 & 0.0 & 0 & 0.0 & 0 & 0.0 \\
\hline BROMUS & 0 & 0.0 & 0 & 0.0 & 0.1 & 0.1 & 0.09 & 0.2 & 0 & 0.0 & 0 & 0.0 & 0 & 0.0 & 0 & 0.0 & 0 & 0.0 & 0 & 0.0 \\
\hline BROTEC & 0 & 0.0 & 0 & 0.0 & 0.1 & 0.1 & 0 & 0.0 & 0 & 0.0 & 0 & 0.0 & 0 & 0.0 & 0 & 0.0 & 0 & 0.0 & 0 & 0.0 \\
\hline CALMON & 0.66 & 0.4 & 0.66 & 0.3 & 0.1 & 3.5 & 0.09 & 1.0 & 0 & 0.0 & 0 & 0.0 & 0 & 0.0 & 0 & 0.0 & 0 & 0.0 & 0 & 0.0 \\
\hline CALPUR & 0.33 & 0.5 & 0 & 0.0 & 0 & 0.0 & 0 & 0.0 & 0 & 0.0 & 0 & 0.0 & 0 & 0.0 & 0 & 0.0 & 0 & 0.0 & 0 & 0.0 \\
\hline CARDUR & 0.66 & 0.4 & 0.66 & 0.5 & 0.3 & 0.3 & 0.27 & 0.3 & 0 & 0.0 & 1 & 0.1 & 1 & 1.3 & 1 & 0.2 & 1 & 0.2 & 0.66 & 0.7 \\
\hline CAREX & 0.33 & 0.1 & 0.33 & 0.4 & 0.1 & 0.5 & 0 & 0.0 & 0 & 0.0 & 0 & 0.0 & 0 & 0.0 & 0 & 0.0 & 0 & 0.0 & 0 & 0.0 \\
\hline CARFIL & 0 & 0.0 & 0 & 0.0 & 0.2 & 15.0 & 0.27 & 10.2 & 0 & 0.0 & 0 & 0.0 & 0.33 & 2.1 & 0.5 & 59.0 & 0 & 0.0 & 0 & 0.0 \\
\hline CARGEY & 0 & 0.0 & 0 & 0.0 & 0 & 0.0 & 0 & 0.0 & 0 & 0.0 & 0 & 0.0 & 0 & 0.0 & 0 & 0.0 & 0 & 0.0 & 0 & 0.0 \\
\hline CARHOO & 0 & 0.0 & 0 & 0.0 & 0 & 0.0 & 0 & 0.0 & 0 & 0.0 & 0 & 0.0 & 0 & 0.0 & 0 & 0.0 & 0 & 0.0 & 0 & 0.0 \\
\hline CARPET & 0 & 0.0 & 0.66 & 0.1 & 0.1 & 0.2 & 0.36 & 0.1 & 0 & 0.0 & 0 & 0.0 & 0 & 0.0 & 0.5 & 0.2 & 0 & 0.0 & 0 & 0.0 \\
\hline CARROI & 0 & 0.0 & 0.33 & 0.7 & 0 & 0.0 & 0.09 & 0.1 & 0 & 0.0 & 0 & 0.0 & 0 & 0.0 & \begin{tabular}{l|l|}
0.5 \\
\end{tabular} & 1.3 & 0 & 0.0 & 0 & 0.0 \\
\hline CARVAL & 0 & 0.0 & 0 & 0.0 & 0 & 0.0 & 0.09 & 1.3 & 0 & 0.0 & 0 & 0.0 & 0 & 0.0 & 0 & 0.0 & 0 & 0.0 & 0 & 0.0 \\
\hline DACGLO & 0 & 0.0 & 0 & 0.0 & 0 & 0.0 & 0 & 0.0 & 0 & 0.0 & 0 & 0.0 & 0 & 0.0 & 0 & 0.0 & 0 & 0.0 & 0 & 0.0 \\
\hline DANINT & 0 & 0.0 & 0 & 0.0 & 0.1 & 0.1 & 0 & 0.0 & 0 & 0.0 & 0 & 0.0 & 0 & 0.0 & 0 & 0.0 & 0 & 0.0 & 0 & 0.0 \\
\hline DANUNI & 0 & 0.0 & 0 & 0.0 & 0 & 0.0 & 0 & 0.0 & 0 & 0.0 & 0 & 0.0 & 0.33 & 4.7 & 0 & 0.0 & 0 & 0.0 & 0 & 0.0 \\
\hline DISSTR & 0 & 0.0 & 0 & 0.0 & 0 & 0.0 & 0 & 0.0 & 0 & 0.0 & 0 & 0.0 & 0 & 0.0 & 0 & 0.0 & 0 & 0.0 & 0 & 0.0 \\
\hline ELYELY & 0 & 0.0 & 0 & 0.0 & 0 & 0.0 & 0 & 0.0 & 0 & 0.0 & 0 & 0.0 & 0 & 0.0 & 0 & 0.0 & 0 & 0.0 & 0 & 0.0 \\
\hline ELYLAN & 0.66 & 4.0 & 0.66 & 3.6 & 0 & 0.0 & 0 & 0.0 & 0 & 0.0 & 0 & 0.0 & 0 & 0.0 & 0 & 0.0 & 0 & 0.0 & 0 & 0.0 \\
\hline ELYTRA & 0 & 0.0 & 0 & 0.0 & 0 & 0.0 & 0.09 & 0.1 & 0 & 0.0 & 0 & 0.0 & 0 & 0.0 & 0 & 0.0 & 0 & 0.0 & 0 & 0.0 \\
\hline FESIDA & 1 & 18.2 & 1 & 19.3 & 1 & 22.1 & 1 & 26.8 & 0 & 0.0 & 0 & 0.0 & 1 & 3.3 & 1 & 7.6 & 0.66 & 0.6 & 0.33 & 0.6 \\
\hline HESCOM & 0 & 0.0 & 0 & 0.0 & 0 & 0.0 & 0 & 0.0 & 1 & 0.4 & 1 & 1.3 & 0 & 0.0 & 0 & 0.0 & 0.66 & 14.6 & 0.66 & 1.2 \\
\hline KOEMAC & 0.66 & 0.3 & 1 & 0.3 & 0.3 & 0.6 & 0.45 & 0.4 & 0 & 0.0 & 0 & 0.0 & 1 & 1.9 & 1 & 0.3 & 1 & 1.4 & 1 & 1.4 \\
\hline LEYCIN & 0 & 0.0 & 0 & 0.0 & 0.1 & 0.3 & 0.18 & 1.2 & 0 & 0.0 & 0 & 0.0 & 0 & 0.0 & 0 & 0.0 & 0 & 0.0 & 0 & 0.0 \\
\hline MELBUL & 0 & 0.0 & 0 & 0.0 & 0 & 0.0 & 0 & 0.0 & 0 & 0.0 & 0 & 0.0 & 0 & 0.0 & 0 & 0.0 & 0 & 0.0 & 0 & 0.0 \\
\hline MELSPE & 0 & 0.0 & 0 & 0.0 & 0 & 0.0 & 0 & 0.0 & 0 & 0.0 & 0 & 0.0 & 0 & 0.0 & 0 & 0.0 & 0 & 0.0 & 0 & 0.0 \\
\hline MUHRIC & 0 & 0.0 & 0.33 & 3.3 & 0.1 & 1.0 & 0.09 & 1.0 & 0 & 0.0 & 0 & 0.0 & 0 & 0.0 & 0.5 & 0.4 & 0 & 0.0 & 0 & 0.0 \\
\hline PASSMI & 0.33 & 5.8 & 0.33 & 1.3 & 0.1 & 1.4 & 0 & 0.0 & 1 & 17.2 & 1 & 12.6 & 0.33 & 2.6 & 0 & 0.0 & 0 & 0.0 & 0 & 0.0 \\
\hline PHLPRA & 0.33 & 0.3 & 0.33 & 0.8 & 0 & 0.0 & 0 & 0.0 & 0 & 0.0 & 0 & 0.0 & 0 & 0.0 & 0 & 0.0 & 0 & 0.0 & 0 & 0.0 \\
\hline POACUS & 0.33 & 0.1 & 0.33 & 0.1 & 0 & 0.0 & 0.18 & 0.1 & 1 & 0.1 & 0 & 0.0 & 0 & 0.0 & 0 & 0.0 & 0 & 0.0 & 0 & 0.0 \\
\hline POAPRA & 0.33 & 1.2 & 0.66 & 9.2 & 0.1 & 2.3 & 0.45 & 1.2 & 0 & 0.0 & 0 & 0.0 & 0 & 0.0 & 0 & 0.0 & 0 & 0.0 & 0 & 0.0 \\
\hline POASEC & 1 & 3.8 & 1 & 2.6 & 1 & 0.7 & 0.72 & 0.3 & 1 & 0.6 & 1 & 0.6 & 1 & 1.3 & 1 & 0.6 & 1 & 0.7 & 1 & 0.8 \\
\hline POAXXX & 0 & 0.0 & 0 & 0.0 & 0 & 0.0 & 0 & 0.0 & 0 & 0.0 & 0 & 0.0 & 0 & 0.0 & 0 & 0.0 & 0 & 0.0 & 0 & 0.0 \\
\hline PSESPI & 1 & 8.3 & 1 & 2.6 & 1 & 13.2 & 1 & 11.0 & 1 & 3.0 & 1 & 11.4 & 1 & 6.1 & 1 & 3.8 & 1 & 21.3 & 1 & 21.0 \\
\hline SPOCRY & 0 & 0.0 & 0 & 0.0 & 0 & 0.0 & 0 & 0.0 & 0 & 0.0 & 0 & 0.0 & 0 & 0.0 & 0 & 0.0 & 0 & 0.0 & 0 & 0.0 \\
\hline
\end{tabular}




\begin{tabular}{|c|c|c|c|c|c|c|c|c|c|c|c|c|c|c|c|c|c|c|c|c|}
\hline \multirow{2}{*}{$\begin{array}{l}\text { SPECIES } \\
\text { Forbs } \\
\end{array}$} & \multicolumn{2}{|c|}{$\begin{array}{c}\text { ARTTSV/FESID } \\
\text { A-PASSMI-B } \\
n=3\end{array}$} & \multicolumn{2}{|c|}{$\begin{array}{c}\text { ARTTSV/FESID } \\
\text { A-PASSMI-C } \\
n=3\end{array}$} & \multicolumn{2}{|c|}{$\begin{array}{c}\text { ARTTSV/FESID } \\
\text { A-PSESPI-B } \\
n=10\end{array}$} & \multicolumn{2}{|c|}{$\begin{array}{c}\text { ARTTSV/FESID } \\
\text { A-PSESPI-C } \\
\mathrm{n}=11\end{array}$} & $\begin{array}{r}\text { ARTTSV } \\
\text { PAS } \\
\mathrm{n}\end{array}$ & $\begin{array}{l}\text { PSESPI- } \\
\text { MI-B } \\
1\end{array}$ & $\begin{array}{r}\text { ARTTSV } \\
\text { PAS } \\
n\end{array}$ & $\begin{array}{l}\text { PSESPF- } \\
\text { M-C } \\
1\end{array}$ & $\begin{array}{l}\text { ART } \\
\text { FESII } \\
\mathrm{n}=\end{array}$ & $\begin{array}{l}S W I \\
A-B \\
3\end{array}$ & $\begin{array}{l}\text { ART } \\
\text { FESII } \\
\mathrm{n}=\end{array}$ & $\begin{array}{l}\text { SWI } \\
A-C \\
2\end{array}$ & $\begin{array}{r}\text { ART } \\
\text { PSES } \\
n=\end{array}$ & $\begin{array}{l}\text { SWI } \\
\text { Pr-B } \\
3\end{array}$ & $\begin{array}{l}\text { ART } \\
\text { PSES } \\
n=\end{array}$ & $\begin{array}{l}\text { SWI } \\
\mathrm{Pl}-\mathrm{C} \\
3\end{array}$ \\
\hline & $\mathrm{CON}$ & $\mathrm{cov}$ & CON & $\mathrm{cov}$ & $\mathrm{CON}$ & $\mathrm{cov}$ & $\mathrm{CON}$ & $\mathrm{cov}$ & $\mathrm{CON}$ & $\mathrm{cov}$ & CON & $\mathrm{cov}$ & CON & cov & $\mathrm{CON}$ & cov & $\mathrm{CON}$ & cov & $\mathrm{CON}$ & $\mathrm{cov}$ \\
\hline ACHMIL & 0.33 & 1.0 & 0.66 & 0.4 & 0.9 & 0.7 & 1 & 0.3 & 0 & 0.0 & 0 & 0.0 & 0.66 & 0.1 & 1 & 0.7 & 0 & 0.0 & 0 & 0.0 \\
\hline AGOGLA & 0 & 0.0 & 0 & 0.0 & 0.4 & 0.1 & 0.63 & 0.2 & 0 & 0.0 & 0 & 0.0 & 0 & 0.0 & 0 & 0.0 & 0.33 & 0.1 & 0 & 0.0 \\
\hline AGOSER & 0 & 0.0 & 0 & 0.0 & 0.1 & 0.1 & 0 & 0.0 & 0 & 0.0 & 0 & 0.0 & 0 & 0.0 & 0 & 0.0 & 0 & 0.0 & 0 & 0.0 \\
\hline ALLCER & 0 & 0.0 & 0 & 0.0 & 0.3 & 0.1 & 0.45 & 0.1 & 0 & 0.0 & 0 & 0.0 & 0 & 0.0 & 0 & 0.0 & 0 & 0.0 & 0 & 0.0 \\
\hline ALLIUM & 0 & 0.0 & 0 & 0.0 & 0 & 0.0 & 0 & 0.0 & 0 & 0.0 & 0 & 0.0 & 0 & 0.0 & 0 & 0.0 & 0 & 0.0 & 0 & 0.0 \\
\hline ALLTEX & 0.33 & 0.1 & 0 & 0.0 & 0.3 & 0.1 & 0.09 & 0.5 & 0 & 0.0 & 0 & 0.0 & 0.33 & 0.2 & 0.5 & 0.2 & 0.33 & 0.2 & 0.33 & 0.3 \\
\hline ALYDES & 0 & 0.0 & 0 & 0.0 & 0 & 0.0 & 0 & 0.0 & 0 & 0.0 & 0 & 0.0 & 0 & 0.0 & 0 & 0.0 & 0 & 0.0 & 0 & 0.0 \\
\hline ANDOCC & 0 & 0.0 & 0 & 0.0 & 0 & 0.0 & 0 & 0.0 & 0 & 0.0 & 0 & 0.0 & 0 & 0.0 & 0 & 0.0 & 0 & 0.0 & 0 & 0.0 \\
\hline ANDSEP & 0 & 0.0 & 0 & 0.0 & 0.1 & 0.1 & 0 & 0.0 & 0 & 0.0 & 0 & 0.0 & 0 & 0.0 & 0 & 0.0 & 0 & 0.0 & 0 & 0.0 \\
\hline ANEM UL & 0 & 0.0 & 0 & 0.0 & 0 & 0.0 & 0 & 0.0 & 0 & 0.0 & 0 & 0.0 & 0 & 0.0 & 0 & 0.0 & 0 & 0.0 & 0 & 0.0 \\
\hline ANEPAT & 0 & 0.0 & 0 & 0.0 & 0 & 0.0 & 0 & 0.0 & 0 & 0.0 & 0 & 0.0 & 0 & 0.0 & 0 & 0.0 & 0 & 0.0 & 0 & 0.0 \\
\hline ANTANA & 0 & 0.0 & 0.33 & 0.1 & 0 & 0.0 & 0 & 0.0 & 0 & 0.0 & 0 & 0.0 & 0 & 0.0 & 0.5 & 1.0 & 0 & 0.0 & 0 & 0.0 \\
\hline ANTROS & 1 & 6.3 & 1 & 2.6 & 1 & 2.3 & 1 & 1.3 & 1 & 0.6 & 1 & 0.8 & 1 & 3.3 & 1 & 2.3 & 0.66 & 0.5 & 0.33 & 1.8 \\
\hline ANTUMB B & 0 & 0.0 & 0 & 0.0 & 0 & 0.0 & 0.09 & 0.5 & 0 & 0.0 & 0 & 0.0 & 0 & 0.0 & 0 & 0.0 & 0 & 0.0 & 0 & 0.0 \\
\hline ARABIS & 0 & 0.0 & 0 & 0.0 & 0 & 0.0 & 0 & 0.0 & 0 & 0.0 & 0 & 0.0 & 0 & 0.0 & 0 & 0.0 & 0 & 0.0 & 0 & 0.0 \\
\hline ARACAP & 0 & 0.0 & 0 & 0.0 & 0 & 0.0 & 0.09 & 0.1 & 0 & 0.0 & 0 & 0.0 & 0 & 0.0 & 0 & 0.0 & 0 & 0.0 & 0 & 0.0 \\
\hline ARADRU & 0.66 & 0.1 & 0.33 & 0.2 & 0.5 & 0.1 & 0.36 & 0.1 & 0 & 0.0 & 0 & 0.0 & 0 & 0.0 & 0 & 0.0 & 0 & 0.0 & 0.33 & 0.3 \\
\hline ARAGLA & 0 & 0.0 & 0 & 0.0 & 0 & 0.0 & 0 & 0.0 & 0 & 0.0 & 0 & 0.0 & 0 & 0.0 & 0 & 0.0 & 0 & 0.0 & 0 & 0.0 \\
\hline ARAHOL & 0 & 0.0 & 0 & 0.0 & 0.2 & 0.1 & 0.09 & 0.1 & 0 & 0.0 & 0 & 0.0 & 0 & 0.0 & 0.5 & 0.0 & 0 & 0.0 & 0 & 0.0 \\
\hline ARANUT & 0 & 0.0 & 0 & 0.0 & 0 & 0.0 & 0.09 & 0.1 & 0 & 0.0 & 0 & 0.0 & 0 & 0.0 & 0.5 & 0.1 & 0 & 0.0 & 0 & 0.0 \\
\hline ARASPA & 0 & 0.0 & 0 & 0.0 & 0 & 0.0 & 0.09 & 0.3 & 0 & 0.0 & 0 & 0.0 & 0 & 0.0 & 0 & 0.0 & 0 & 0.0 & 0 & 0.0 \\
\hline ARECAP & 0.33 & 0.1 & 0.66 & 0.2 & 0.7 & 0.4 & 0.36 & 0.4 & 0 & 0.0 & 0 & 0.0 & 0.66 & 0.2 & 0.5 & 0.3 & 0.66 & 0.4 & 0.66 & 0.4 \\
\hline ARECON & 0.33 & 1.1 & 0.33 & 0.2 & 0 & 0.0 & 0 & 0.0 & 0 & 0.0 & 0 & 0.0 & 0 & 0.0 & 0 & 0.0 & 0 & 0.0 & 0 & 0.0 \\
\hline AREKIN & 0 & 0.0 & 0 & 0.0 & 0 & 0.0 & 0 & 0.0 & 0 & 0.0 & 0 & 0.0 & 0.33 & 0.8 & 0.5 & 0.4 & 0 & 0.0 & 0 & 0.0 \\
\hline ARNSOR & 0 & 0.0 & 0.33 & 0.7 & 0.7 & 1.4 & 0.72 & 1.3 & 0 & 0.0 & 0 & 0.0 & 1 & 0.3 & 1 & 0.0 & 0 & 0.0 & 0 & 0.0 \\
\hline ARTARB & 0 & 0.0 & 0 & 0.0 & 0 & 0.0 & 0 & 0.0 & 0 & 0.0 & 0 & 0.0 & 0.33 & 17.1 & 0 & 0.0 & 0 & 0.0 & 0 & 0.0 \\
\hline ARTLUD & 0 & 0.0 & 0.33 & 3.3 & 0.1 & 0.1 & 0 & 0.0 & 0 & 0.0 & 0 & 0.0 & 0 & 0.0 & 0 & 0.0 & 0 & 0.0 & 0 & 0.0 \\
\hline ASTADS & 0.33 & 1.0 & 0.33 & 1.4 & 0.2 & 0.7 & 0.09 & 0.1 & 0 & 0.0 & 0 & 0.0 & 0 & 0.0 & 0 & 0.0 & 0.33 & 2.0 & 0.66 & 1.0 \\
\hline ASTAGR & 0.33 & 0.5 & 0.66 & 0.1 & 0.4 & 0.1 & 0.36 & 0.2 & 0 & 0.0 & 0 & 0.0 & 0 & 0.0 & 0.5 & 0.0 & 0 & 0.0 & 0 & 0.0 \\
\hline ASTATR & 0 & 0.0 & 0 & 0.0 & 0.1 & 0.4 & 0.09 & 0.8 & 0 & 0.0 & 0 & 0.0 & 0 & 0.0 & 0 & 0.0 & 0 & 0.0 & 0 & 0.0 \\
\hline ASTCAM & 0.33 & 1.8 & 0.33 & 6.3 & 0 & 0.0 & 0 & 0.0 & 0 & 0.0 & 0 & 0.0 & 0 & 0.0 & 0 & 0.0 & 0 & 0.0 & 0 & 0.0 \\
\hline ASTCHI & 0 & 0.0 & 0 & 0.0 & 0 & 0.0 & 0 & 0.0 & 0 & 0.0 & 0 & 0.0 & 0 & 0.0 & 0 & 0.0 & 0 & 0.0 & 0 & 0.0 \\
\hline ASTER & 0 & 0.0 & 0 & 0.0 & 0 & 0.0 & 0 & 0.0 & 0 & 0.0 & 0 & 0.0 & 0 & 0.0 & 0 & 0.0 & 0 & 0.0 & 0 & 0.0 \\
\hline ASTFAL & 0 & 0.0 & 0 & 0.0 & 0 & 0.0 & 0.09 & 0.1 & 0 & 0.0 & 0 & 0.0 & 0 & 0.0 & 0 & 0.0 & 0 & 0.0 & 0 & 0.0 \\
\hline ASTLEN & 0 & 0.0 & 0.33 & 0.1 & 0 & 0.0 & 0 & 0.0 & 0 & 0.0 & 0 & 0.0 & 0 & 0.0 & 0 & 0.0 & 0 & 0.0 & 0 & 0.0 \\
\hline ASTM IS & 1 & 0.4 & 0.66 & 0.2 & 0.7 & 1.8 & 0.36 & 3.0 & 0 & 0.0 & 0 & 0.0 & 0.66 & 0.3 & 0.5 & 0.3 & 0.66 & 0.5 & 0.66 & 0.4 \\
\hline ASTPUR & 0.33 & 0.1 & 0.33 & 0.1 & 0.1 & 0.1 & 0 & 0.0 & 0 & 0.0 & 0 & 0.0 & 0 & 0.0 & 0 & 0.0 & 0 & 0.0 & 0.33 & 0.1 \\
\hline ASTRAD & 0 & 0.0 & 0 & 0.0 & 0 & 0.0 & 0 & 0.0 & 0 & 0.0 & 0 & 0.0 & 0 & 0.0 & 0 & 0.0 & 0 & 0.0 & 0 & 0.0 \\
\hline ASTRAG & 0 & 0.0 & 0 & 0.0 & 0 & 0.0 & 0 & 0.0 & 0 & 0.0 & 0 & 0.0 & 0 & 0.0 & 0 & 0.0 & 0 & 0.0 & 0 & 0.0 \\
\hline ASTSCA & 0 & 0.0 & 0 & 0.0 & 0.1 & 0.1 & 0.09 & 0.1 & 1 & 0.1 & 1 & 0.3 & 0.33 & 0.6 & 0.5 & 0.8 & 0.66 & 0.3 & 0.66 & 0.4 \\
\hline BALSAG & 0 & 0.0 & 0 & 0.0 & 0.2 & 0.6 & 0.36 & 0.3 & 0 & 0.0 & 0 & 0.0 & 0 & 0.0 & 0 & 0.0 & 0 & 0.0 & 0 & 0.0 \\
\hline BESWYO & 0.33 & 0.3 & 0.33 & 0.1 & 0.1 & 2.0 & 0.09 & 1.7 & 0 & 0.0 & 0 & 0.0 & 0.33 & 0.1 & 0.5 & 0.1 & 0 & 0.0 & 0 & 0.0 \\
\hline BOIGLA & 0 & 0.0 & 0 & 0.0 & 0.1 & 0.5 & 0.09 & 0.1 & 0 & 0.0 & 0 & 0.0 & 0 & 0.0 & 0 & 0.0 & 0 & 0.0 & 0 & 0.0 \\
\hline BUPAME & 0 & 0.0 & 0 & 0.0 & 0.1 & 0.2 & 0 & 0.0 & 0 & 0.0 & 0 & 0.0 & 0 & 0.0 & 0 & 0.0 & 0 & 0.0 & 0 & 0.0 \\
\hline CALEUR & 0 & 0.0 & 0 & 0.0 & 0 & 0.0 & 0 & 0.0 & 0 & 0.0 & 0 & 0.0 & 0 & 0.0 & 0 & 0.0 & 0 & 0.0 & 0 & 0.0 \\
\hline CAMMIC & 0 & 0.0 & 0 & 0.0 & 0.1 & 0.1 & 0 & 0.0 & 0 & 0.0 & 0 & 0.0 & 0 & 0.0 & 0 & 0.0 & 0.33 & 0.2 & 0 & 0.0 \\
\hline CAMROT & 0 & 0.0 & 0 & 0.0 & 0 & 0.0 & 0 & 0.0 & 0 & 0.0 & 0 & 0.0 & 0 & 0.0 & 0 & 0.0 & 0 & 0.0 & 0 & 0.0 \\
\hline CANUNI & 0 & 0.0 & 0 & 0.0 & 0 & 0.0 & 0 & 0.0 & 0 & 0.0 & 0 & 0.0 & 0 & 0.0 & 0.5 & 1.8 & 0 & 0.0 & 0 & 0.0 \\
\hline CASANG & 0 & 0.0 & 0 & 0.0 & 0 & 0.0 & 0 & 0.0 & 0 & 0.0 & 0 & 0.0 & 0 & 0.0 & 0 & 0.0 & 0.33 & 0.3 & 0.66 & 0.1 \\
\hline CASPAL & 0 & 0.0 & 0.33 & 0.1 & 0.6 & 0.3 & 0.81 & 0.4 & 0 & 0.0 & 0 & 0.0 & 0.33 & 0.1 & 0 & 0.0 & 0 & 0.0 & 0 & 0.0 \\
\hline CASSTR & 0 & 0.0 & 0 & 0.0 & 0 & 0.0 & 0.09 & 0.1 & 0 & 0.0 & 0 & 0.0 & 0 & 0.0 & 0 & 0.0 & 0 & 0.0 & 0 & 0.0 \\
\hline CASTIL & 0 & 0.0 & 0 & 0.0 & 0.1 & 0.6 & 0 & 0.0 & 0 & 0.0 & 0 & 0.0 & 0 & 0.0 & 0 & 0.0 & 0 & 0.0 & 0 & 0.0 \\
\hline CERARV & 0.66 & 0.1 & 0.33 & 1.6 & 0 & 0.0 & 0.09 & 0.5 & 0 & 0.0 & 0 & 0.0 & 0 & 0.0 & 0 & 0.0 & 0 & 0.0 & 0 & 0.0 \\
\hline CHADOU & 0 & 0.0 & 0 & 0.0 & 0.1 & 0.1 & 0 & 0.0 & 0 & 0.0 & 0 & 0.0 & 0 & 0.0 & 0 & 0.0 & 0 & 0.0 & 0 & 0.0 \\
\hline CHEALB & 0 & 0.0 & 0 & 0.0 & 0 & 0.0 & 0 & 0.0 & 0 & 0.0 & 0 & 0.0 & 0 & 0.0 & 0 & 0.0 & 0 & 0.0 & 0 & 0.0 \\
\hline CHEFRE & 0 & 0.0 & 0 & 0.0 & 0 & 0.0 & 0 & 0.0 & 0 & 0.0 & 0 & 0.0 & 0 & 0.0 & 0 & 0.0 & 0 & 0.0 & 0 & 0.0 \\
\hline CHELEP & 0 & 0.0 & 0 & 0.0 & 0 & 0.0 & 0 & 0.0 & 0 & 0.0 & 0 & 0.0 & 0 & 0.0 & 0 & 0.0 & 0 & 0.0 & 0 & 0.0 \\
\hline CHENOP & 0 & 0.0 & 0 & 0.0 & 0.1 & 0.1 & 0.09 & 0.1 & 0 & 0.0 & 0 & 0.0 & 0 & 0.0 & 0 & 0.0 & 0 & 0.0 & 0 & 0.0 \\
\hline CIRSCA & 0 & 0.0 & 0 & 0.0 & 0 & 0.0 & 0 & 0.0 & 0 & 0.0 & 0 & 0.0 & 0 & 0.0 & 0 & 0.0 & 0 & 0.0 & 0 & 0.0 \\
\hline CIRSIU & 0 & 0.0 & 0 & 0.0 & 0.1 & 0.1 & 0 & 0.0 & 0 & 0.0 & 0 & 0.0 & 0 & 0.0 & 0 & 0.0 & 0 & 0.0 & 0 & 0.0 \\
\hline CLEHIR & 0 & 0.0 & 0 & 0.0 & 0 & 0.0 & 0 & 0.0 & 0 & 0.0 & 0 & 0.0 & 0 & 0.0 & 0 & 0.0 & 0 & 0.0 & 0 & 0.0 \\
\hline COLLIN & 0 & 0.0 & 0 & 0.0 & 0.1 & 0.2 & 0 & 0.0 & 0 & 0.0 & 0 & 0.0 & 0 & 0.0 & 0 & 0.0 & 0 & 0.0 & 0 & 0.0 \\
\hline COLPAR & 0 & 0.0 & 0 & 0.0 & 0.3 & 0.2 & 0.45 & 0.3 & 0 & 0.0 & 0 & 0.0 & 0 & 0.0 & 0 & 0.0 & 0 & 0.0 & 0 & 0.0 \\
\hline COMUMB & 0.66 & 0.2 & 0.66 & 0.3 & 0.3 & 0.2 & 0.27 & 0.6 & 0 & 0.0 & 0 & 0.0 & 0 & 0.0 & 0 & 0.0 & 0 & 0.0 & 0 & 0.0 \\
\hline CORRAM & 0 & 0.0 & 0 & 0.0 & 0 & 0.0 & 0 & 0.0 & 0 & 0.0 & 1 & 1.5 & 0 & 0.0 & 0 & 0.0 & 0 & 0.0 & 0 & 0.0 \\
\hline CREACU & 0 & 0.0 & 0 & 0.0 & 0.1 & 1.0 & 0.09 & 0.3 & 0 & 0.0 & 0 & 0.0 & 0 & 0.0 & 0 & 0.0 & 0 & 0.0 & 0 & 0.0 \\
\hline
\end{tabular}




\begin{tabular}{|c|c|c|c|c|c|c|c|c|c|c|c|c|c|c|c|c|c|c|c|c|}
\hline \multirow{2}{*}{$\begin{array}{l}\text { SPECIES } \\
\text { Forbs }\end{array}$} & \multicolumn{2}{|c|}{$\begin{array}{c}\text { ARTTSV/FESID } \\
\text { A-PASSMI-B } \\
n=3\end{array}$} & \multicolumn{2}{|c|}{\begin{tabular}{|c|} 
ARTTSV/FESID \\
A-PASSMIC \\
$n=3$
\end{tabular}} & \multicolumn{2}{|c|}{$\begin{array}{c}\text { ARTTSV/FESID } \\
\text { A-PSESPI-B } \\
n=10\end{array}$} & \multicolumn{2}{|c|}{$\begin{array}{c}\text { ARTTSV/FESID } \\
\text { A-PSESPI-C } \\
n=11\end{array}$} & $\begin{array}{r}\text { ARTTSV } \\
\text { PAS } \\
n\end{array}$ & \begin{tabular}{l|l} 
PSESPI- \\
MI-B \\
1
\end{tabular} & $\begin{array}{r}\text { ARTTSV } \\
\text { PAS } \\
n\end{array}$ & $\begin{array}{l}\text { PSESPI- } \\
\mathrm{MI} C \\
1\end{array}$ & $\begin{array}{l}\text { ART } \\
\text { FESII } \\
n=\end{array}$ & $\begin{array}{l}\text { SW/ } \\
\text { DA-B } \\
=3\end{array}$ & $\begin{array}{l}\text { ART } \\
\text { FESII } \\
n=\end{array}$ & $\begin{array}{l}\text { SWI } \\
\text { DA-C } \\
2\end{array}$ & $\begin{array}{r}\text { ARTT } \\
\text { PSES } \\
\mathrm{n}=\end{array}$ & $\begin{array}{l}\text { SWI } \\
\text { PI-B } \\
3\end{array}$ & $\begin{array}{c}\text { ARTT } \\
\text { PSES } \\
n=\end{array}$ & $\begin{array}{l}\text { SWI } \\
\text { PI-C } \\
=3\end{array}$ \\
\hline & CON & $\mathrm{cov}$ & CON & $\mathrm{cov}$ & $\mathrm{CON}$ & $\mathrm{cov}$ & CON & $\mathrm{cov}$ & $\mathrm{CON}$ & $\mathrm{cov}$ & CON & cov & $\mathrm{CON}$ & cov & CON & $\mathrm{cov}$ & CON & cov & CON & cov \\
\hline CREATR & 0 & 0.0 & 0 & 0.0 & 0.1 & 0.1 & 0 & 0.0 & 0 & 0.0 & 0 & 0.0 & 0 & 0.0 & 0 & 0.0 & 0 & 0.0 & 0 & 0.0 \\
\hline CREM OD & 0 & 0.0 & 0 & 0.0 & 0.1 & 0.1 & 0.27 & 1.1 & 0 & 0.0 & 0 & 0.0 & 0 & 0.0 & 0.5 & 0.2 & 0.66 & 0.6 & 0.66 & 0.5 \\
\hline CREPIS & 0 & 0.0 & 0 & 0.0 & 0 & 0.0 & 0 & 0.0 & 0 & 0.0 & 0 & 0.0 & 0 & 0.0 & 0.5 & 0.1 & 0 & 0.0 & 0.33 & 0.2 \\
\hline CRYPTA & 0 & 0.0 & 0 & 0.0 & 0.1 & 0.5 & 0.09 & 0.1 & 0 & 0.0 & 0 & 0.0 & 0 & 0.0 & 0 & 0.0 & 0 & 0.0 & 0 & 0.0 \\
\hline CYMBIP & 0.33 & 0.1 & 0 & 0.0 & 0.1 & 0.1 & 0.18 & 0.1 & 0 & 0.0 & 0 & 0.0 & 0 & 0.0 & 0 & 0.0 & 0 & 0.0 & 0 & 0.0 \\
\hline CYNOFF & 0 & 0.0 & 0 & 0.0 & 0 & 0.0 & 0.09 & 0.1 & 0 & 0.0 & 0 & 0.0 & 0 & 0.0 & 0 & 0.0 & 0 & 0.0 & 0 & 0.0 \\
\hline CYSFRA & 0 & 0.0 & 0 & 0.0 & 0 & 0.0 & 0.18 & 0.1 & 0 & 0.0 & 0 & 0.0 & 0 & 0.0 & 0 & 0.0 & 0 & 0.0 & 0 & 0.0 \\
\hline DELBIC & 0 & 0.0 & 0 & 0.0 & 0.2 & 0.2 & 0.18 & 1.4 & 0 & 0.0 & 0 & 0.0 & 0 & 0.0 & 0 & 0.0 & 0 & 0.0 & 0 & 0.0 \\
\hline DESRIC & 0 & 0.0 & 0 & 0.0 & 0 & 0.0 & 0 & 0.0 & 0 & 0.0 & 0 & 0.0 & 0 & 0.0 & 0 & 0.0 & 0 & 0.0 & 0.33 & 0.1 \\
\hline DESSOP & 0 & 0.0 & 0 & 0.0 & 0 & 0.0 & 0 & 0.0 & 0 & 0.0 & 0 & 0.0 & 0 & 0.0 & 0 & 0.0 & 0 & 0.0 & 0 & 0.0 \\
\hline DODCON & 0.33 & 0.1 & 0 & 0.0 & 0.1 & 0.1 & 0.27 & 0.3 & 0 & 0.0 & 0 & 0.0 & 0 & 0.0 & 0 & 0.0 & 0 & 0.0 & 0 & 0.0 \\
\hline DOUM ON & 0 & 0.0 & 0 & 0.0 & 0 & 0.0 & 0.09 & 0.1 & 0 & 0.0 & 0 & 0.0 & 0 & 0.0 & 0 & 0.0 & 0 & 0.0 & 0 & 0.0 \\
\hline DRABAX & 0 & 0.0 & 0 & 0.0 & 0.1 & 0.1 & 0 & 0.0 & 0 & 0.0 & 0 & 0.0 & 0 & 0.0 & 0 & 0.0 & 0 & 0.0 & 0 & 0.0 \\
\hline DRANEM & 0 & 0.0 & 0.33 & 0.1 & 0.1 & 0.1 & 0.18 & 0.2 & 0 & 0.0 & 0 & 0.0 & 0 & 0.0 & 0 & 0.0 & 0 & 0.0 & 0 & 0.0 \\
\hline DRASTE & 0 & 0.0 & 0 & 0.0 & 0.1 & 0.1 & 0.09 & 0.1 & 0 & 0.0 & 0 & 0.0 & 0 & 0.0 & 0 & 0.0 & 0 & 0.0 & 0 & 0.0 \\
\hline EPIPAN & 0 & 0.0 & 0 & 0.0 & 0 & 0.0 & 0 & 0.0 & 0 & 0.0 & 0 & 0.0 & 0 & 0.0 & 0 & 0.0 & 0 & 0.0 & 0 & 0.0 \\
\hline ERICES & 0 & 0.0 & 0 & 0.0 & 0 & 0.0 & 0 & 0.0 & 0 & 0.0 & 0 & 0.0 & 0 & 0.0 & 0 & 0.0 & 0 & 0.0 & 0.33 & 0.1 \\
\hline ERICOM & 0 & 0.0 & 0 & 0.0 & 0.2 & 0.4 & 0.27 & 0.1 & 0 & 0.0 & 0 & 0.0 & 0.33 & 0.1 & 0.5 & 0.2 & 0.33 & 0.2 & 0.66 & 0.1 \\
\hline ERICOR & 0 & 0.0 & 0 & 0.0 & 0.6 & 1.3 & 0.45 & 2.0 & 0 & 0.0 & 0 & 0.0 & 0.66 & 0.1 & 0 & 0.0 & 0 & 0.0 & 0 & 0.0 \\
\hline ERIFLA & 0 & 0.0 & 0 & 0.0 & 0 & 0.0 & 0 & 0.0 & 0 & 0.0 & 0 & 0.0 & 0 & 0.0 & 0 & 0.0 & 0 & 0.0 & 0 & 0.0 \\
\hline ERIGER & 0 & 0.0 & 0 & 0.0 & 0 & 0.0 & 0.09 & 0.1 & 0 & 0.0 & 0 & 0.0 & 0 & 0.0 & 0 & 0.0 & 0 & 0.0 & 0 & 0.0 \\
\hline ERIHER & 0 & 0.0 & 0 & 0.0 & 0 & 0.0 & 0 & 0.0 & 0 & 0.0 & 0 & 0.0 & 0 & 0.0 & 0 & 0.0 & 0 & 0.0 & 0 & 0.0 \\
\hline ERILIN & 0 & 0.0 & 0 & 0.0 & 0 & 0.0 & 0.09 & 0.1 & 0 & 0.0 & 0 & 0.0 & 0 & 0.0 & 0 & 0.0 & 0 & 0.0 & 0 & 0.0 \\
\hline ERIMIC & 0 & 0.0 & 0 & 0.0 & 0.1 & 0.4 & 0 & 0.0 & 0 & 0.0 & 0 & 0.0 & 0.33 & 0.1 & 0 & 0.0 & 0 & 0.0 & 0.33 & 0.1 \\
\hline ERIOVA & 0 & 0.0 & 0 & 0.0 & 0.1 & 0.4 & 0 & 0.0 & 0 & 0.0 & 0 & 0.0 & 0 & 0.0 & 0 & 0.0 & 0 & 0.0 & 0 & 0.0 \\
\hline ERIPUM & 0 & 0.0 & 0 & 0.0 & 0 & 0.0 & 0 & 0.0 & 0 & 0.0 & 0 & 0.0 & 0 & 0.0 & 0 & 0.0 & 0 & 0.0 & 0 & 0.0 \\
\hline ERISPE & 0 & 0.0 & 0 & 0.0 & 0 & 0.0 & 0 & 0.0 & 0 & 0.0 & 0 & 0.0 & 0 & 0.0 & 0 & 0.0 & 0 & 0.0 & 0 & 0.0 \\
\hline ERITWE & 0 & 0.0 & 0 & 0.0 & 0 & 0.0 & 0 & 0.0 & 0 & 0.0 & 0 & 0.0 & 0 & 0.0 & 0 & 0.0 & 0.33 & 0.3 & 0.33 & 0.2 \\
\hline ERIUMB & 0 & 0.0 & 0.66 & 0.2 & 0.3 & 0.7 & 0.45 & 1.5 & 0 & 0.0 & 0 & 0.0 & 0.33 & 0.1 & 0.5 & 0.1 & 0 & 0.0 & 0 & 0.0 \\
\hline \begin{tabular}{|l} 
ERYCHE \\
\end{tabular} & 0 & 0.0 & 0 & 0.0 & 0 & 0.0 & 0 & 0.0 & 0 & 0.0 & 0 & 0.0 & 0 & 0.0 & 0 & 0.0 & 0 & 0.0 & 0 & 0.0 \\
\hline ERYINC & 0 & 0.0 & 0 & 0.0 & 0 & 0.0 & 0 & 0.0 & 0 & 0.0 & 0 & 0.0 & 0 & 0.0 & 0 & 0.0 & 0 & 0.0 & 0 & 0.0 \\
\hline FRASPE & 0 & 0.0 & 0 & 0.0 & 0.1 & 0.5 & 0 & 0.0 & 0 & 0.0 & 0 & 0.0 & 0 & 0.0 & 0 & 0.0 & 0 & 0.0 & 0 & 0.0 \\
\hline FRAVES & 0 & 0.0 & 0 & 0.0 & 0 & 0.0 & 0 & 0.0 & 0 & 0.0 & 0 & 0.0 & 0 & 0.0 & 0 & 0.0 & 0 & 0.0 & 0 & 0.0 \\
\hline FRIPUD & 0 & 0.0 & 0 & 0.0 & 0 & 0.0 & 0.09 & 0.2 & 0 & 0.0 & 0 & 0.0 & 0 & 0.0 & 0 & 0.0 & 0 & 0.0 & 0 & 0.0 \\
\hline GALBIF & 0 & 0.0 & 0 & 0.0 & 0 & 0.0 & 0.09 & 0.1 & 0 & 0.0 & 0 & 0.0 & 0 & 0.0 & 0 & 0.0 & 0 & 0.0 & 0 & 0.0 \\
\hline GENAFF & 0 & 0.0 & 0 & 0.0 & 0 & 0.0 & 0 & 0.0 & 0 & 0.0 & 0 & 0.0 & 0 & 0.0 & 0.5 & 1.2 & 0 & 0.0 & 0 & 0.0 \\
\hline GERRIC & 0 & 0.0 & 0 & 0.0 & 0 & 0.0 & 0 & 0.0 & 0 & 0.0 & 0 & 0.0 & 0 & 0.0 & 0 & 0.0 & 0 & 0.0 & 0 & 0.0 \\
\hline GERVIS & 0 & 0.0 & 0 & 0.0 & 0 & 0.0 & 0.18 & 0.5 & 0 & 0.0 & 0 & 0.0 & 0 & 0.0 & 0 & 0.0 & 0 & 0.0 & 0 & 0.0 \\
\hline GEUTRI & 0 & 0.0 & 0.33 & 0.4 & 0.3 & 0.5 & 0.27 & 0.7 & 0 & 0.0 & 0 & 0.0 & 0.33 & 0.3 & 0.5 & 0.9 & 0 & 0.0 & 0 & 0.0 \\
\hline GILTER & 0 & 0.0 & 0 & 0.0 & 0.1 & 0.1 & 0 & 0.0 & 0 & 0.0 & 0 & 0.0 & 0 & 0.0 & 0 & 0.0 & 0 & 0.0 & 0 & 0.0 \\
\hline HACMIC & 0 & 0.0 & 0.33 & 0.1 & 0 & 0.0 & 0 & 0.0 & 0 & 0.0 & 0 & 0.0 & 0 & 0.0 & 0 & 0.0 & 0 & 0.0 & 0 & 0.0 \\
\hline HACPAT & 0 & 0.0 & 0 & 0.0 & 0 & 0.0 & 0 & 0.0 & 0 & 0.0 & 0 & 0.0 & 0 & 0.0 & 0 & 0.0 & 0 & 0.0 & 0 & 0.0 \\
\hline HAPACA & 0 & 0.0 & 0 & 0.0 & 0.2 & 0.1 & 0.09 & 0.2 & 0 & 0.0 & 0 & 0.0 & 0 & 0.0 & 0.5 & 0.1 & 0.33 & 0.2 & 0.33 & 0.1 \\
\hline HAPINT & 0 & 0.0 & 0 & 0.0 & 0 & 0.0 & 0 & 0.0 & 0 & 0.0 & 0 & 0.0 & 0 & 0.0 & 0 & 0.0 & 0 & 0.0 & 0 & 0.0 \\
\hline HAPUNI & 0.33 & 0.4 & 0 & 0.0 & 0 & 0.0 & 0 & 0.0 & 0 & 0.0 & 0 & 0.0 & 0 & 0.0 & 0 & 0.0 & 0 & 0.0 & 0 & 0.0 \\
\hline HEDHIS & 0 & 0.0 & 0 & 0.0 & 0 & 0.0 & 0 & 0.0 & 0 & 0.0 & 0 & 0.0 & 0 & 0.0 & 0 & 0.0 & 0 & 0.0 & 0 & 0.0 \\
\hline HELUNI & 0 & 0.0 & 0 & 0.0 & 0 & 0.0 & 0 & 0.0 & 0 & 0.0 & 0 & 0.0 & 0 & 0.0 & 0 & 0.0 & 0 & 0.0 & 0 & 0.0 \\
\hline HETVIL & 0 & 0.0 & 0 & 0.0 & 0.1 & 2.2 & 0 & 0.0 & 0 & 0.0 & 0 & 0.0 & 0 & 0.0 & 0 & 0.0 & 0.33 & 0.1 & 0 & 0.0 \\
\hline HEUPAR & 0.66 & 0.1 & 0.33 & 0.1 & 0.4 & 0.3 & 0.09 & 0.1 & 0 & 0.0 & 0 & 0.0 & 0 & 0.0 & 0 & 0.0 & 0 & 0.0 & 0 & 0.0 \\
\hline HIECYN & 0 & 0.0 & 0 & 0.0 & 0 & 0.0 & 0 & 0.0 & 0 & 0.0 & 0 & 0.0 & 0 & 0.0 & 0 & 0.0 & 0 & 0.0 & 0 & 0.0 \\
\hline HYDCAP & 0 & 0.0 & 0 & 0.0 & 0 & 0.0 & 0 & 0.0 & 0 & 0.0 & 0 & 0.0 & 0 & 0.0 & 0 & 0.0 & 0 & 0.0 & 0 & 0.0 \\
\hline KOCsco & 0 & 0.0 & 0 & 0.0 & 0 & 0.0 & 0 & 0.0 & 0 & 0.0 & 0 & 0.0 & 0 & 0.0 & 0 & 0.0 & 0 & 0.0 & 0 & 0.0 \\
\hline LAPRED & 0.33 & 0.1 & 0 & 0.0 & 0.2 & 0.1 & 0 & 0.0 & 0 & 0.0 & 0 & 0.0 & 0.33 & 0.4 & 0 & 0.0 & 0.33 & 0.1 & 0 & 0.0 \\
\hline LEPCAM & 0 & 0.0 & 0 & 0.0 & 0 & 0.0 & 0 & 0.0 & 0 & 0.0 & 0 & 0.0 & 0 & 0.0 & 0 & 0.0 & 0 & 0.0 & 0 & 0.0 \\
\hline LEPDEN & 0 & 0.0 & 0 & 0.0 & 0 & 0.0 & 0 & 0.0 & 0 & 0.0 & 0 & 0.0 & 0 & 0.0 & 0 & 0.0 & 0 & 0.0 & 0 & 0.0 \\
\hline LEPIDI & 0 & 0.0 & 0 & 0.0 & 0 & 0.0 & 0 & 0.0 & 0 & 0.0 & 0 & 0.0 & 0 & 0.0 & 0 & 0.0 & 0 & 0.0 & 0 & 0.0 \\
\hline LESALP & 0 & 0.0 & 0 & 0.0 & 0 & 0.0 & 0 & 0.0 & 0 & 0.0 & 0 & 0.0 & 0 & 0.0 & 0 & 0.0 & 0 & 0.0 & 0 & 0.0 \\
\hline LEWRED & 0 & 0.0 & 0 & 0.0 & 0.1 & 0.2 & 0.09 & 0.4 & 0 & 0.0 & 0 & 0.0 & 0.33 & 0.1 & 0 & 0.0 & 0.33 & 0.2 & 0.66 & 0.1 \\
\hline LINLEW & 0 & 0.0 & 0 & 0.0 & 0 & 0.0 & 0 & 0.0 & 0 & 0.0 & 0 & 0.0 & 0 & 0.0 & 0 & 0.0 & 0 & 0.0 & 0 & 0.0 \\
\hline LITINC & 0 & 0.0 & 0 & 0.0 & 0 & 0.0 & 0 & 0.0 & 1 & 0.1 & 0 & 0.0 & 0 & 0.0 & 0 & 0.0 & 0 & 0.0 & 0 & 0.0 \\
\hline LITPAR & 0 & 0.0 & 0 & 0.0 & 0 & 0.0 & 0.09 & 0.2 & 0 & 0.0 & 0 & 0.0 & 0 & 0.0 & 0 & 0.0 & 0 & 0.0 & 0 & 0.0 \\
\hline LITRUD & 0 & 0.0 & 0 & 0.0 & 0.2 & 3.0 & 0.27 & 0.6 & 0 & 0.0 & 0 & 0.0 & 0 & 0.0 & 0 & 0.0 & 0 & 0.0 & 0 & 0.0 \\
\hline LOMCOU & 0.33 & 0.4 & 0.33 & 0.6 & 0.3 & 0.1 & 0.09 & 0.1 & 0 & 0.0 & 0 & 0.0 & 0 & 0.0 & 0 & 0.0 & 0 & 0.0 & 0 & 0.0 \\
\hline LOMFOE & 0 & 0.0 & 0 & 0.0 & 0.1 & 0.4 & 0.09 & 0.3 & 0 & 0.0 & 0 & 0.0 & 0 & 0.0 & 0 & 0.0 & 0.33 & 0.2 & 0.66 & 0.3 \\
\hline LOM TRI & 0 & 0.0 & 0 & 0.0 & 0.1 & 0.1 & 0.36 & 0.2 & 0 & 0.0 & 0 & 0.0 & 0 & 0.0 & 0 & 0.0 & 0 & 0.0 & 0 & 0.0 \\
\hline
\end{tabular}




\begin{tabular}{|c|c|c|c|c|c|c|c|c|c|c|c|c|c|c|c|c|c|c|c|c|}
\hline \multirow{2}{*}{$\begin{array}{l}\text { SPECIES } \\
\text { Forbs }\end{array}$} & \multicolumn{2}{|c|}{$\begin{array}{c}\text { ARTTSV/FESID } \\
\text { A-PASSMI-B } \\
n=3\end{array}$} & \multicolumn{2}{|c|}{$\begin{array}{c}\text { ARTTSV/FESID } \\
\text { A-PASSMI-C } \\
n=3\end{array}$} & \multicolumn{2}{|c|}{$\begin{array}{c}\text { ARTTSV/FESID } \\
\text { A-PSESPI-B } \\
n=10\end{array}$} & \multicolumn{2}{|c|}{$\begin{array}{c}\text { ARTTSV/FESID } \\
\text { A-PSESPI-C } \\
n=11\end{array}$} & \multicolumn{2}{|c|}{$\begin{array}{c}\text { ARTTSW/PSESPI- } \\
\text { PASSMI-B } \\
n=1\end{array}$} & \multicolumn{2}{|c|}{$\begin{array}{c}\text { ARTTSW/PSESPI- } \\
\text { PASSMI-C } \\
n=1\end{array}$} & \multicolumn{2}{|c|}{$\begin{array}{c}\text { ARTTSW/ } \\
\text { FESIDA-B } \\
n=3\end{array}$} & $\begin{array}{l}\text { ARTT } \\
\text { FESID } \\
n=\end{array}$ & $\begin{array}{l}\text { SWI } \\
\text { A-C } \\
2\end{array}$ & $\begin{array}{c}\text { ARTT } \\
\text { PSES } \\
n=\end{array}$ & & $\begin{array}{c}\text { ARTT } \\
\text { PSES } \\
n=\end{array}$ & $\begin{array}{l}\text { SWI } \\
\text { Pl-C } \\
3\end{array}$ \\
\hline & CON & $\mathrm{cov}$ & $\mathrm{CON}$ & $\mathrm{cov}$ & CON & $\mathrm{cov}$ & CON & $\operatorname{cov}$ & CON & $\operatorname{cov}$ & CON & cov & CON & $\mathrm{cov}$ & CON & $\mathrm{cov}$ & CON & $\mathrm{cov}$ & CON & $\mathrm{cov}$ \\
\hline LUPARG & 0 & 0.0 & 0.66 & 2.6 & 0.1 & 0.9 & 0.09 & 3.0 & 0 & 0.0 & 0 & 0.0 & 0 & 0.0 & 0 & 0.0 & 0 & 0.0 & 0 & 0.0 \\
\hline LUPINU & 0 & 0.0 & 0 & 0.0 & 0 & 0.0 & 0 & 0.0 & 0 & 0.0 & 0 & 0.0 & 0 & 0.0 & 0 & 0.0 & 0 & 0.0 & 0 & 0.0 \\
\hline LUPLEU & 0 & 0.0 & 0 & 0.0 & 0 & 0.0 & 0 & 0.0 & 0 & 0.0 & 0 & 0.0 & 0 & 0.0 & 0.5 & 4.3 & 0 & 0.0 & 0 & 0.0 \\
\hline LUPSER & 0 & 0.0 & 0 & 0.0 & 0.7 & 5.1 & 0.81 & 4.8 & 0 & 0.0 & 0 & 0.0 & 0 & 0.0 & 0 & 0.0 & 0 & 0.0 & 0 & 0.0 \\
\hline LUPWYE & 이 & 0.0 & 0 & 0.0 & 0 & 0.0 & 0.09 & 9.7 & 0 & 0.0 & 0 & 0.0 & 0 & 0.0 & 0.5 & 2.0 & 0 & 0.0 & 0 & 0.0 \\
\hline MACCAN & 0 & 0.0 & 0 & 0.0 & 0.1 & 0.1 & 0 & 0.0 & 1 & 0.3 & 1 & 0.1 & 0 & 0.0 & 0 & 0.0 & 0 & 0.0 & 0 & 0.0 \\
\hline MACHAE & 0 & 0.0 & 0 & 0.0 & 0 & 0.0 & 0 & 0.0 & 0 & 0.0 & 0 & 0.0 & 0 & 0.0 & 0 & 0.0 & 0 & 0.0 & 0 & 0.0 \\
\hline MEROBL & 0.33 & 0.1 & 0 & 0.0 & 0.4 & 0.2 & 0.45 & 1.0 & 0 & 0.0 & 0 & 0.0 & 0.66 & 0.2 & 0.5 & 0.4 & 0.33 & 0.3 & 0.33 & 0.2 \\
\hline MICGRA & 0 & 0.0 & 0 & 0.0 & 0 & 0.0 & 0 & 0.0 & 0 & 0.0 & 0 & 0.0 & 0 & 0.0 & 0 & 0.0 & 0 & 0.0 & 0 & 0.0 \\
\hline MICNUT & 0 & 0.0 & 0 & 0.0 & 0.1 & 0.0 & 0 & 0.0 & 0 & 0.0 & 0 & 0.0 & 0 & 0.0 & 0 & 0.0 & 0 & 0.0 & 0 & 0.0 \\
\hline MUSDIV & 0 & 0.0 & 0 & 0.0 & 0 & 0.0 & 0 & 0.0 & 0 & 0.0 & 0 & 0.0 & 0 & 0.0 & 0.5 & 0.1 & 0 & 0.0 & 0 & 0.0 \\
\hline MYOSYL & 0.33 & 0.1 & 0.33 & 0.2 & 0 & 0.0 & 0 & 0.0 & 0 & 0.0 & 0 & 0.0 & 0 & 0.0 & 0 & 0.0 & 0 & 0.0 & 0 & 0.0 \\
\hline NEMBRE & 0 & 0.0 & 0 & 0.0 & 0 & 0.0 & 0 & 0.0 & 0 & 0.0 & 0 & 0.0 & 0 & 0.0 & 0 & 0.0 & 0 & 0.0 & 0 & 0.0 \\
\hline NOTTRO & 0 & 0.0 & 0 & 0.0 & 0.5 & 0.2 & 0.36 & 0.3 & 0 & 0.0 & 0 & 0.0 & 0.33 & 0.1 & 0.5 & 0.3 & 0.33 & 0.2 & 0.33 & 0.2 \\
\hline OENOTH & 0 & 0.0 & 0 & 0.0 & 0 & 0.0 & 0 & 0.0 & 0 & 0.0 & 0 & 0.0 & 0 & 0.0 & 0 & 0.0 & 0 & 0.0 & 0 & 0.0 \\
\hline OXYLAG & 0 & 0.0 & 0 & 0.0 & 0.2 & 0.1 & 0 & 0.0 & 0 & 0.0 & 0 & 0.0 & 0 & 0.0 & 0 & 0.0 & 0 & 0.0 & 0 & 0.0 \\
\hline OXYSER & 0 & 0.0 & 0 & 0.0 & 0 & 0.0 & 0 & 0.0 & 0 & 0.0 & 0 & 0.0 & 0 & 0.0 & 0.5 & 0.2 & 0.33 & 1.0 & 0.33 & 0.1 \\
\hline OXYVIS & 0 & 0.0 & 0 & 0.0 & 0.1 & 0.1 & 0.09 & 0.1 & 0 & 0.0 & 0 & 0.0 & 0 & 0.0 & 0 & 0.0 & 0 & 0.0 & 0 & 0.0 \\
\hline PEDPAR & 0 & 0.0 & 0 & 0.0 & 0 & 0.0 & 0 & 0.0 & 0 & 0.0 & 0 & 0.0 & 0 & 0.0 & 0.5 & 0.1 & 0 & 0.0 & 0 & 0.0 \\
\hline PEDSIM & 0 & 0.0 & 0 & 0.0 & 0 & 0.0 & 0 & 0.0 & 0 & 0.0 & 1 & 0.2 & 0 & 0.0 & 0 & 0.0 & 0 & 0.0 & 0 & 0.0 \\
\hline PENARI & 0.33 & 0.1 & 0 & 0.0 & 0.3 & 0.3 & 0.09 & 0.1 & 0 & 0.0 & 0 & 0.0 & 0.66 & 0.2 & 0.5 & 0.9 & 0.66 & 0.1 & 0.66 & 0.1 \\
\hline PENERI & 0 & 0.0 & 0 & 0.0 & 0 & 0.0 & 0.09 & 0.1 & 0 & 0.0 & 0 & 0.0 & 0 & 0.0 & 0.5 & 0.1 & 0 & 0.0 & 0 & 0.0 \\
\hline PENPRO & 0 & 0.0 & 0 & 0.0 & 0 & 0.0 & 0.18 & 0.2 & 0 & 0.0 & 0 & 0.0 & 0 & 0.0 & 0.5 & 0.1 & 0 & 0.0 & 0 & 0.0 \\
\hline PENRAD & 0 & 0.0 & 0 & 0.0 & 0 & 0.0 & 0 & 0.0 & 0 & 0.0 & 0 & 0.0 & 0.33 & 0.5 & 0 & 0.0 & 0 & 0.0 & 0.33 & 0.2 \\
\hline PERGAI & 0 & 0.0 & 0 & 0.0 & 0 & 0.0 & 0 & 0.0 & 0 & 0.0 & 0 & 0.0 & 0 & 0.0 & 0 & 0.0 & 0 & 0.0 & 0 & 0.0 \\
\hline PHAHAS & 0 & 0.0 & 0 & 0.0 & 0.1 & 1.0 & 0 & 0.0 & 0 & 0.0 & 0 & 0.0 & 0 & 0.0 & 0 & 0.0 & 0 & 0.0 & 0 & 0.0 \\
\hline PHALIN & 0 & 0.0 & 0 & 0.0 & 0.2 & 1.7 & 0.18 & 0.2 & 0 & 0.0 & 0 & 0.0 & 0.33 & 0.1 & 0 & 0.0 & 0.33 & 1.0 & 0.33 & 0.7 \\
\hline PHLCAE & 0 & 0.0 & 0 & 0.0 & 0 & 0.0 & 0 & 0.0 & 0 & 0.0 & 0 & 0.0 & 0 & 0.0 & 0 & 0.0 & 0 & 0.0 & 0 & 0.0 \\
\hline PHLHOO & 0.33 & 0.7 & 0.33 & 0.4 & 0.6 & 1.0 & 0.36 & 0.5 & 1 & 3.1 & 1 & 3.7 & 0.66 & 2.7 & 0.5 & 0.1 & 1 & 1.7 & 1 & 0.8 \\
\hline PHLLON & 0.33 & 0.1 & 0.33 & 0.2 & 0.9 & 0.4 & 1 & 0.3 & 0 & 0.0 & 0 & 0.0 & 0 & 0.0 & 0.5 & 0.1 & 0.33 & 0.4 & 0.66 & 0.4 \\
\hline PHLMUL & 0 & 0.0 & 0 & 0.0 & 0 & 0.0 & 0.09 & 3.0 & 0 & 0.0 & 0 & 0.0 & 0 & 0.0 & 0 & 0.0 & 0 & 0.0 & 0 & 0.0 \\
\hline PHLMUS & 0.33 & 0.8 & 0.33 & 0.1 & 0.1 & 0.7 & 0.18 & 0.7 & 0 & 0.0 & 0 & 0.0 & 0.66 & 2.7 & 0.5 & 0.6 & 0 & 0.0 & 0.33 & 0.1 \\
\hline POLDOU & 0.33 & 0.1 & 0.33 & 0.1 & 0 & 0.0 & 0 & 0.0 & 0 & 0.0 & 0 & 0.0 & 0 & 0.0 & 0 & 0.0 & 0 & 0.0 & 0 & 0.0 \\
\hline POTARG & 0 & 0.0 & 0 & 0.0 & 0 & 0.0 & 0 & 0.0 & 0 & 0.0 & 0 & 0.0 & 0 & 0.0 & 0 & 0.0 & 0 & 0.0 & 0 & 0.0 \\
\hline POTGLA & 0 & 0.0 & 0 & 0.0 & 0 & 0.0 & 0 & 0.0 & 0 & 0.0 & 0 & 0.0 & 0 & 0.0 & 0 & 0.0 & 0 & 0.0 & 0 & 0.0 \\
\hline POTGRA & 0.33 & 1.0 & 0.66 & 2.7 & 0.1 & 0.1 & 0.09 & 0.3 & 0 & 0.0 & 0 & 0.0 & 0 & 0.0 & 0 & 0.0 & 0 & 0.0 & 0 & 0.0 \\
\hline RANALI & 0 & 0.0 & 0 & 0.0 & 0 & 0.0 & 0 & 0.0 & 0 & 0.0 & 0 & 0.0 & 0 & 0.0 & 0 & 0.0 & 0 & 0.0 & 0 & 0.0 \\
\hline RANGLA & 0 & 0.0 & 0.33 & 0.2 & 0 & 0.0 & 0.09 & 0.2 & 0 & 0.0 & 0 & 0.0 & 0 & 0.0 & 0.5 & 0.1 & 0 & 0.0 & 0 & 0.0 \\
\hline RANUNC & 0 & 0.0 & 0 & 0.0 & 0 & 0.0 & 0 & 0.0 & 0 & 0.0 & 0 & 0.0 & 0.33 & 0.1 & 0 & 0.0 & 0 & 0.0 & 0 & 0.0 \\
\hline RUMPAU & 0 & 0.0 & 0 & 0.0 & 0 & 0.0 & 0 & 0.0 & 0 & 0.0 & 0 & 0.0 & 0 & 0.0 & 0 & 0.0 & 0 & 0.0 & 0 & 0.0 \\
\hline SCHLIN & 0 & 0.0 & 0 & 0.0 & 0.1 & 0.1 & 0.09 & 0.1 & 0 & 0.0 & 0 & 0.0 & 0.33 & 0.1 & 0.5 & 0.1 & 0.33 & 0.1 & 0.33 & 0.1 \\
\hline SEDLAN & 0 & 0.0 & 0 & 0.0 & 0.1 & 0.4 & 0.18 & 0.3 & 0 & 0.0 & 0 & 0.0 & 0.33 & 0.5 & 0 & 0.0 & 0 & 0.0 & 0 & 0.0 \\
\hline SELDEN & 0.33 & 0.1 & 0 & 0.0 & 0.2 & 9.2 & 0 & 0.0 & 0 & 0.0 & 0 & 0.0 & 0 & 0.0 & 0 & 0.0 & 0.33 & 1.1 & 0 & 0.0 \\
\hline SENCRA & 0 & 0.0 & 0 & 0.0 & 0.1 & 0.3 & 0.09 & 0.3 & 0 & 0.0 & 0 & 0.0 & 0.33 & 0.1 & 0 & 0.0 & 0 & 0.0 & 0 & 0.0 \\
\hline SENINT & 0 & 0.0 & 0 & 0.0 & 0.1 & 0.1 & 0.09 & 0.5 & 0 & 0.0 & 0 & 0.0 & 0 & 0.0 & 0 & 0.0 & 0 & 0.0 & 0 & 0.0 \\
\hline SILDOU & 0 & 0.0 & 0 & 0.0 & 0 & 0.0 & 0.09 & 0.5 & 0 & 0.0 & 0 & 0.0 & 0 & 0.0 & 0 & 0.0 & 0 & 0.0 & 0 & 0.0 \\
\hline SILDRU & 0 & 0.0 & 0.33 & 1.0 & 0.2 & 0.1 & 0 & 0.0 & 0 & 0.0 & 0 & 0.0 & 0 & 0.0 & 0 & 0.0 & 0 & 0.0 & 0 & 0.0 \\
\hline SISALT & 0 & 0.0 & 0 & 0.0 & 0 & 0.0 & 0 & 0.0 & 0 & 0.0 & 0 & 0.0 & 0 & 0.0 & 0 & 0.0 & 0 & 0.0 & 0 & 0.0 \\
\hline SOLIDA & 0 & 0.0 & 0 & 0.0 & 0.1 & 0.1 & 0.09 & 0.5 & 0 & 0.0 & 0 & 0.0 & 0 & 0.0 & 0 & 0.0 & 0 & 0.0 & 0 & 0.0 \\
\hline SOLMIS & 0 & 0.0 & 0 & 0.0 & 0 & 0.0 & 0 & 0.0 & 0 & 0.0 & 0 & 0.0 & 0 & 0.0 & 0 & 0.0 & 0 & 0.0 & 0 & 0.0 \\
\hline SOLMUL & 0 & 0.0 & 0.33 & 0.1 & 0.1 & 0.1 & 0.09 & 0.3 & 0 & 0.0 & 0 & 0.0 & 0 & 0.0 & 0 & 0.0 & 0 & 0.0 & 0 & 0.0 \\
\hline SPHCOC & 0.33 & 0.2 & 0 & 0.0 & 0 & 0.0 & 0 & 0.0 & 1 & 0.3 & 1 & 0.1 & 0.66 & 0.4 & 0.5 & 0.1 & 0.66 & 0.3 & 0.33 & 0.1 \\
\hline STERUN & 0 & 0.0 & 0 & 0.0 & 0 & 0.0 & 0 & 0.0 & 1 & 0.1 & 0 & 0.0 & 0 & 0.0 & 0 & 0.0 & 0 & 0.0 & 0 & 0.0 \\
\hline TARLAE & 0 & 0.0 & 0 & 0.0 & 0 & 0.0 & 0 & 0.0 & 0 & 0.0 & 0 & 0.0 & 0 & 0.0 & 0 & 0.0 & 0 & 0.0 & 0 & 0.0 \\
\hline TAROFF & 0.33 & 10.6 & 0.66 & 4.7 & 0.6 & 3.5 & 0.81 & 1.8 & 0 & 0.0 & 1 & 0.1 & 0 & 0.0 & 0.5 & 0.4 & 1 & 0.5 & 0.66 & 0.2 \\
\hline TRADUB & 0 & 0.0 & 0 & 0.0 & 0.3 & 0.1 & 0.09 & 0.1 & 0 & 0.0 & 0 & 0.0 & 0 & 0.0 & 0 & 0.0 & 0.66 & 0.1 & 0.66 & 0.1 \\
\hline TRILON & 0.33 & 0.4 & 0.33 & 0.7 & 0 & 0.0 & 0 & 0.0 & 0 & 0.0 & 0 & 0.0 & 0 & 0.0 & 0 & 0.0 & 0 & 0.0 & 0 & 0.0 \\
\hline VIONUT & 0 & 0.0 & 0.33 & 0.3 & 0.5 & 0.3 & 0.54 & 0.3 & 0 & 0.0 & 0 & 0.0 & 0.66 & 0.2 & 0.5 & 0.7 & 0 & 0.0 & 0 & 0.0 \\
\hline ZIGVEN & 0 & 0.0 & 0 & 0.0 & 0.2 & 0.7 & 0.18 & 0.2 & 0 & 0.0 & 0 & 0.0 & 0.33 & 0.4 & 0.5 & 0.2 & 0 & 0.0 & 0 & 0.0 \\
\hline
\end{tabular}


Key to six-character codes used in Constancy / Cover Tables; ordered alphabetically by lifeform

\begin{tabular}{|c|c|c|}
\hline \multicolumn{3}{|c|}{ Shrubs \& Subshrubs } \\
\hline ARTART & Artemisia arbuscula & little sagebrush \\
\hline ARTFRI & A. frigida & prairie sagewort \\
\hline ARTTRP & A.tripartita & threetip sagebrush \\
\hline \begin{tabular}{|l|} 
ARTTST \\
\end{tabular} & A. tridentata ssp. tridentata & basin big sagebrush \\
\hline ARTTSV & A. tridentata ssp. vaseyana & mountain big sagebrush \\
\hline ARTTSW & A. tridentata ssp. womingensis & Wyoming big sagebrush \\
\hline MAHREP & Mahonia repens & creeping barberry \\
\hline CHRNAU & Ericameria nauseosa & rubber rabbitbrush \\
\hline \begin{tabular}{|l|} 
CHRVIS \\
\end{tabular} & Chrysothamnus nauseosus & yellow rabbitbrush \\
\hline GUTSAR & Gutierrizia sarothrae & broom snakeweed \\
\hline JUNSCO & Juniperus scopulorum & Rocky M ountain juniper \\
\hline KRALAN & Krascheninnikova lanata & winterfat \\
\hline OPUFRA & Opuntia fragilis & brittle pricklypear \\
\hline OPUPOL & Opuntia polyacantha & plains pricklypear \\
\hline SARVER & Sarcobatus vermiculatus & greasewood \\
\hline SYMOCC & Symphoricarpos occidentalis & western snowberry \\
\hline SYMORE & Symphoricarpos oreophilus & mountain snowberry \\
\hline TETCAN & Tetradymia canescens & spineless horsebrush \\
\hline \multicolumn{3}{|c|}{ Graminoids } \\
\hline ACHHYM & Achnatherum hymenoides & Indian ricegrass \\
\hline $\mathrm{ACHOCC}$ & A.occidentale & western needlegrass \\
\hline ACHRIC & A. richardsonii & Richardson's needlegrass \\
\hline AGRHUM & Agrostis humilis & alpine bentgrass \\
\hline BOUGRA & Bouteloua gracilis & blue grama \\
\hline BROANO & Bromus anomalus & nodding brome \\
\hline BROCAR & \begin{tabular}{|l|} 
B. carinatus \\
\end{tabular} & Californiabrome \\
\hline BROINE & B. inermis & smooth brome \\
\hline BROMUS & Bromus spp. & brome species \\
\hline BROTEC & B.tectorum & cheatgrass \\
\hline CALMON & Calamagrostis montanensis & plains reedgrass \\
\hline CALPUR & C. purpurascens & purple reedgrass \\
\hline CARDUR & Carex duriuscula & needleleaf sedge \\
\hline CAREX & Carex spp. & sedge species \\
\hline CARFIL & C. filifolia & threadleaf sedge \\
\hline CARGEY & C. geyeri & elk sedge \\
\hline CARHOO & C. hoodii & Hood's sedge \\
\hline CARPET & C. petasata & Liddon sedge \\
\hline \begin{tabular}{|l|} 
CARROI \\
\end{tabular} & C. rossii & Ross' sedge \\
\hline CARVAL & C. vallicola & Valleysedge \\
\hline DACGLO & Dactylis glomerata & Orchardgrass \\
\hline DANINT & Danthonia intermedia & timber oatgrass \\
\hline
\end{tabular}

\begin{tabular}{|c|c|c|}
\hline \multicolumn{3}{|c|}{ Graminoids continued } \\
\hline DANUNI & D. unispicata & onspike danthonia \\
\hline DISSPI & Distichlis spicata & inland saltgrass \\
\hline ELYELYY & Elymus elymoides & squirreltail \\
\hline ELYLAN & E. lanceolatus & thickspike wheatgrass \\
\hline ELYTRA & E. trachycaulis & slender wheatgrass \\
\hline FESIDA & Festucaidahoensis & Idaho fescue \\
\hline HESCOM & Hesperostipa comata & needle-and-thread \\
\hline KOEMAC & Koeleria macrantha & prairie Junegrass \\
\hline LEYCIN & Leymus cinereus & \begin{tabular}{|l|l|} 
basin wildrye \\
\end{tabular} \\
\hline MELBUL & Melica bulbosa & oniongrass \\
\hline MELSPE & M. spectabilis & purple oniongrass \\
\hline MUHRIC & Muhlenbergia richardsonis & mat muhly \\
\hline PASSMI & Passcopyrum smithii & western wheatgrass \\
\hline PHLPRA & Phleum pratense & timothy \\
\hline POACUS & Poacusickii & Cusick's bluegrass \\
\hline POAPRA & P. pratensis & Kentucky bluegrass \\
\hline POASEC & Poasecunda & Sandberg bluegrass \\
\hline POA & Poaspp. & bluegrass species \\
\hline PSESPI & Pseudoroegneria spicata & bluebunch wheatgrass \\
\hline SPOCRY & Sporobolus cryptandrus & sand dropseed \\
\hline \multicolumn{3}{|c|}{ Forbs } \\
\hline ACHMIL & Achillea millefolium & common yarrow \\
\hline AGOGLA & Agoseris glauca & pale agoseris \\
\hline AGOSER & Agroseris spp. & agoseris species \\
\hline ALLCER & Allium cernuum & nodding onion \\
\hline ALLIUM & Allium spp. & onion species \\
\hline ALLTEX & A. textile & textile onion \\
\hline ALYDES & Allysum derertorum & desert madwort \\
\hline ANDOCC & Androsace occidentalis & western rockjasmine \\
\hline ANDSEP & A. septentrionalis & pygmyflower rockjasmine \\
\hline ANEMUL & Anemone multifida & Pacific anemone \\
\hline ANEPAT & Anemone patens & cutleaf anemone \\
\hline ANTANA & Antennaria anaphaloides & pearly pussytoes \\
\hline ANTROS & A. rosea & rosypussytoes \\
\hline ANTUMB & A. umbrinella & umber pussytoes \\
\hline ARABIS & Artabis spp. & rockcress species \\
\hline ARACAP & Arenaria capillaris & fescue sandwort \\
\hline$\overline{\text { ARADRU }}$ & A. drummondii & Drummond's rockcress \\
\hline ARAGLA & A. glabra & tower rockcress \\
\hline ARAHOI & A. holboellii & Holboell's rockcress \\
\hline ARANUT & A. nuttallii & Nuttall's rockcress \\
\hline
\end{tabular}

\begin{tabular}{|c|c|c|}
\hline \multicolumn{3}{|c|}{ Forbs Continued } \\
\hline ARASPA & A. sparsiflora & elegant rockcress \\
\hline ARECAP & Arenaria capillaris & fescue sandwort \\
\hline ARECON & A. congesta & ballhead sandwort \\
\hline AREKIN & A. kingii & King's sandwort \\
\hline ARNSOR & Arnica sororia & twin arnica \\
\hline ARTLUD & Artemisia ludo viciana & White sagebrush \\
\hline ASTADS & Astragalus adsurgens & prairie milkvetch \\
\hline ASTAGR & A. agrestis & purple milkvetch \\
\hline ASTATR & A. atropubescens & hangingpod milkvetch \\
\hline ASTCAM & Aster campestris & western meadowaster \\
\hline ASTCHI & A. chilensis & Pacific aster \\
\hline ASTER & Aster spp. & aster species \\
\hline ASTFAL & A. falcatus & white prairie aster \\
\hline ASTLEN & Astragalus lentiginosus & freckled milkvetch \\
\hline ASTMIS & A. miser & timber milkvetch \\
\hline ASTPUR & A. purshii & wo ollypod milkvetch \\
\hline ASTRAG & Astragalus spp. & milkvetch species \\
\hline ASTSCA & Aster scopulorum & see IONALP \\
\hline BALSAG & Balsamorhiza sagittata & arroweaf balsamroot \\
\hline BESWYO & Bessieya wyomingensis & Wyoming besseya \\
\hline BOIGLA & Boisduvalia glabella & smooth spike-primrose \\
\hline BUPAME & Bupleurum americanum & American thorowax \\
\hline CALEUR & Calochortus eurycarpus & white mariposalily \\
\hline CAMMIC & Camelina microcarpa & littlepod false flax \\
\hline CAMROT & Campanula rotundifolia & bluebell bellflower \\
\hline CAMUNI & C. uniflora & arctic bellflower \\
\hline CASANG & Castilleja angustifolia & northwestern Indian paintbrush \\
\hline CASPAL & C. pallescens & pale Indian paintbrush \\
\hline CASTIL & Castilleja spp. & paintbrush species \\
\hline CERARV & Cerastium arvense & field chickweed \\
\hline CHADOU & Chaenactis douglasii & Douglas' dustymaiden \\
\hline CHEALB & Chenopodium album & lambsquarter \\
\hline CHEFRE & C. fremontii & Fremont's goosefoot \\
\hline CHELEP & C. leptophyllum & narrowleaf goosefoot \\
\hline CHENOP & Chenopodium spp. & goosefoot species \\
\hline CIRSCA & Cirsium scariosum & meadowthistle \\
\hline CIRSIU & \begin{tabular}{|l|} 
Cirsium spp. \\
\end{tabular} & thistle species \\
\hline CLEHIR & Clematis hirsutissima & hairyclematis \\
\hline COLLIN & Collinsia spp. & blue-eyed Maryspecies \\
\hline COLPAR & C. parviflora & maiden blue-eyed $M$ ary \\
\hline COMUMB & Comandra umbellata & bastard to adflax \\
\hline
\end{tabular}

\begin{tabular}{|c|c|c|}
\hline \multicolumn{3}{|c|}{ Forbs Continued } \\
\hline CORRAM & Cordylanthus ramosus & bush bird's beak \\
\hline CREACU & Crepis acuminata & tapertip hawksbeard \\
\hline CREATR & C.atribarba & slender hawksbeard \\
\hline CREMOD & C.modocensis & Modoc hawksbeard \\
\hline CREPIS & Crepis spp. & hawksbeard species \\
\hline CRYPTA & Cryptantha spp. & cryptantha species \\
\hline CYMBIP & Cymopteris bipinnatus & snowine springparsley \\
\hline CYNOFF & Cynoglossum officinale & gypsyflower \\
\hline CYSFRA & Cystopteris fragilis & brittle bladderfern \\
\hline DELBIC & Delphinium bicolor & little larkspur \\
\hline DESRIC & Descurainia richardsonii & mountain tansymustard \\
\hline DESSOP & D. sophia & herb sophia \\
\hline DODCON & Dodecatheon conjugens & Bonneville shootingstar \\
\hline DOUMON & Douglasia montana & Rocky Mountain primrose \\
\hline DRABAX & Draba spp. & draba species \\
\hline DRANEM & D. nemorosa & woodland draba \\
\hline DRASTE & D. stenoloba & slender draba \\
\hline EPIPAN & Epilobium paniculatum & tall annual willowherb \\
\hline ERICES & Erigeroncaespitosus & tufted fleabane \\
\hline ERICOM & E. compositus & cutleaf fleabane \\
\hline ERICOR & E. corymbosus & Iongleaf fleabane \\
\hline ERIFLA & Eriogonum flavum & alpine go Iden buckwheat \\
\hline ERIGER & Erigeron spp. & fleabane species \\
\hline ERIHER & Eriogonum heracleoides & parsnipflower buckwheat \\
\hline ERILIN & Erigeron linearis & desert yellowfleabane \\
\hline ERIMIC & Eriogonum microthecum & slender buckwheat \\
\hline ERIOVA & E. ovalifolium & cushion buckwheat \\
\hline ERIPUM & Erigeron pumilus & shaggy fleabane \\
\hline ERISPE & E. speciosus & alpine fleabane \\
\hline ERITWE & E.tweedyi & Tweedys fleabane \\
\hline ERIUMB B & Eriogonum umbellatum & sulfur-flower buckwheat \\
\hline ERYCHE & Erysimum cheiranthoides & wormseed wallflower \\
\hline ERYINC & E. inconspicuum & shy wallflower \\
\hline FRASPE & Frasera speciosa & elkweed \\
\hline FRAVES & Fragaria vesca & woodland strawberry \\
\hline FRIPUD & Fritillaria pudica & yellow fritillary \\
\hline GALBIF & Galium bifolium & twinleaf bedstraw \\
\hline GENAFF & Gentiana affinis & pleated gentian \\
\hline GERRIC & Geranium richardsonii & Richardson's geranium \\
\hline GERVIS & G. viscosissimum & sticky purple geranium \\
\hline GEUTRI & Geum triflorum & old man's whiskers \\
\hline GILTER & Gilia tenerrima & delicate gilia \\
\hline HACMIC & Hackelia micrantha & Jessica sticktight \\
\hline
\end{tabular}

\begin{tabular}{|c|c|c|}
\hline \multicolumn{3}{|c|}{ Forbs Continued } \\
\hline HACPAT & H. patens & spotted stickseed \\
\hline HAPACA & Haplopappus acaulis & stemless mock goldenweed \\
\hline HAPINT & H. integrifolius & manysted goldenweed \\
\hline HAPUNI & H. uniflorus & plantain goldenweed \\
\hline HEDHIS & Hedoma hispidula & rough false pennyroyal \\
\hline HELUNI & Helianthella uniflora & oneflower helianthella \\
\hline HETVIL & Heterotheca villosa & hariyfalse goldenaster \\
\hline HEUPAR & Heuchera parviflora & littleflower alumroot \\
\hline HIECYN & Hieracium cynoglossoides & houndstongue hawkweed \\
\hline HYDCAP & Hydro phyllum capitatum & ballhead waterleaf \\
\hline IONALP & Ionactis alpina & lava aster \\
\hline KOCSCO & Kochia scoparia & Mexican-fireweed \\
\hline \begin{tabular}{|l|} 
LAPRED \\
\end{tabular} & Lappula redows $k i$ & flatspine stickseed \\
\hline LEPCAM & Lepidium campestre & field pepperweed \\
\hline LEPDEN & L. densifflorum & common pepperweed \\
\hline LEPIDI & Lepidium spp. & Pepperweed species \\
\hline LESALP & Lesquerella alpina & alpine bladderpod \\
\hline LEWRED & Lewisia rediviva & bitterroot \\
\hline LINLEW & Linum lewisii & prairie flax \\
\hline LITINC & Lithospermum incisum & narrowleaf stoneseed \\
\hline LITPAR & Lithophragma parviflorum & smallflower wo odland-star \\
\hline LITRUD & Lithospermum ruderale & western stoneseed \\
\hline LOMCOU & Lomatium cous & cous biscuitroot \\
\hline LOMFOE & Lomatium foeniculaceum & desert biscuitroot \\
\hline LOMTRI & L. triternatum & nineleaf biscuitroot \\
\hline LUPARG & Lupinus argenteus & silvery lupine \\
\hline LUPINU & Lupinus spp. & lupine species \\
\hline LUPLEU & L. leucophyllus & velvet lupine \\
\hline LUPSER & L. sericeus & silky lupine \\
\hline LUPWYE & L. wethii & Wyeth's lupine \\
\hline MACCAN & Machaeranthera canescens & hoarytansyaster \\
\hline MACHAE & Machaeranthera spp. & tansyaster species \\
\hline MEROBL & Mertensia oblongifolia & oblongleaf bluebells \\
\hline MICGRA & Microsteris gracilis & microsteris \\
\hline MICNUT & Microseris nutans & nodding microseris \\
\hline MUSDIV & Musineon divaricatum & leafy wildparsley \\
\hline MYOSYL & Myosotis sylvatica & wo odland forget-me-not \\
\hline NEMBRE & Nemophila breviflora & basin nemo phila \\
\hline NOTTRO & Nothocalais troximoides & weevil prairie-dandelion \\
\hline OENOTH & Oenothera spp. & evening-primrose species \\
\hline OXYLAG & Oxytropis lagopus & haresfoot locoweed \\
\hline OXYSER & O. sericea & white locoweed \\
\hline OXYVIS & O. viscida & viscid locoweed \\
\hline
\end{tabular}

\begin{tabular}{|c|c|c|}
\hline \multicolumn{3}{|c|}{ Forbs Continued } \\
\hline PEDPAR & Pedicularis parryi & Parrys lousewort \\
\hline PEDSIM & Pediocactus simpsoni & Simpson hedgehog cactus \\
\hline PENARI & Penstemon aridus & stiffleaf penstemon \\
\hline PENERI & P. eriantherus & fuzzytongue penstemon \\
\hline PENPRO & P. procerus & littleflower penstemon \\
\hline PENRAD & P. radicosus & matroot penstemon \\
\hline PERGAI & Perideridia gairdneri & Gairdner's yampah \\
\hline PHAHAS & Phacelia hastata & silverleaf phacelia \\
\hline PHALIN & P. linearis & threadleaf phacelia \\
\hline PHLCAE & Phloxcaespitosa & tufted phlox \\
\hline PHLHOO & P. hoodii & Hood's phlox \\
\hline PHLLON & P. longifolia & Iongleaf phlox \\
\hline PHLMUL & P. multiflora & phloxmultiflora \\
\hline PHLMUS & P. bryoides & moss phlox \\
\hline POLDOU & Polygonum douglasii & Douglas' knotweed \\
\hline POTARG & Potentilla arguta & tall cinquifoil \\
\hline POTGLA & P. glandulosa & sticky cinqufoil \\
\hline POTGRA & P. gracilis & slender cinquefoil \\
\hline RANALI & Ranunculus alismifolius & plantainleaf buttercup \\
\hline RANGLA & R. glaberrimus & sagebrush buttercut \\
\hline RANUNC & Ranunculus spp. & buttercup spp. \\
\hline RUMPAU & Rumexpaucifolius & alpine sheep sorrel \\
\hline SCHLIN & Schoenocrambe linifolia & flaxleaf plainsmustard \\
\hline SEDLAN & Sedum lanceolatum & spearleaf stonecrop \\
\hline SELDEN & Selaginella densa & lesser spikemoss \\
\hline SENCRA & Senecio crassulus & thickleaf ragwort \\
\hline SENINT & S. integerrimus & lambstongue ragwort \\
\hline SILDOU & Silene douglasii & seabluff catchfly \\
\hline SILDRU & S. drummondii & Drummond's campion \\
\hline SISALT & Sisymbrium altissimum & tall tumblemustard \\
\hline SOLIDA & Solidago spp. & goldenrod species \\
\hline SOLMIS & S. missouriensis & Missouri goldenrod \\
\hline SOLMUL & S. multiradiata & Rocky Mountain goldenrod \\
\hline SPHCOC & Sphaeralcea coccinea & scarlet globemallow \\
\hline STERUN & Stephanomeria runcinata & desert wirelettuce \\
\hline TARLAE & Taraxacum laevigatum & rock dandelion \\
\hline TAROFF & T. officinale & common dandelion \\
\hline TRADUB & Tragopogon dubius & yellowsalsify \\
\hline TRILON & Trifolium longipes & Iongstalk clover \\
\hline VIONUT & \begin{tabular}{|l|l} 
Viola nuttallii \\
\end{tabular} & Nuttall's violet \\
\hline ZIGVEN & Zigadenus venenosus & meadowdeathcamas \\
\hline
\end{tabular}

Appendix C - 9 
Appendix D. Рноtos 

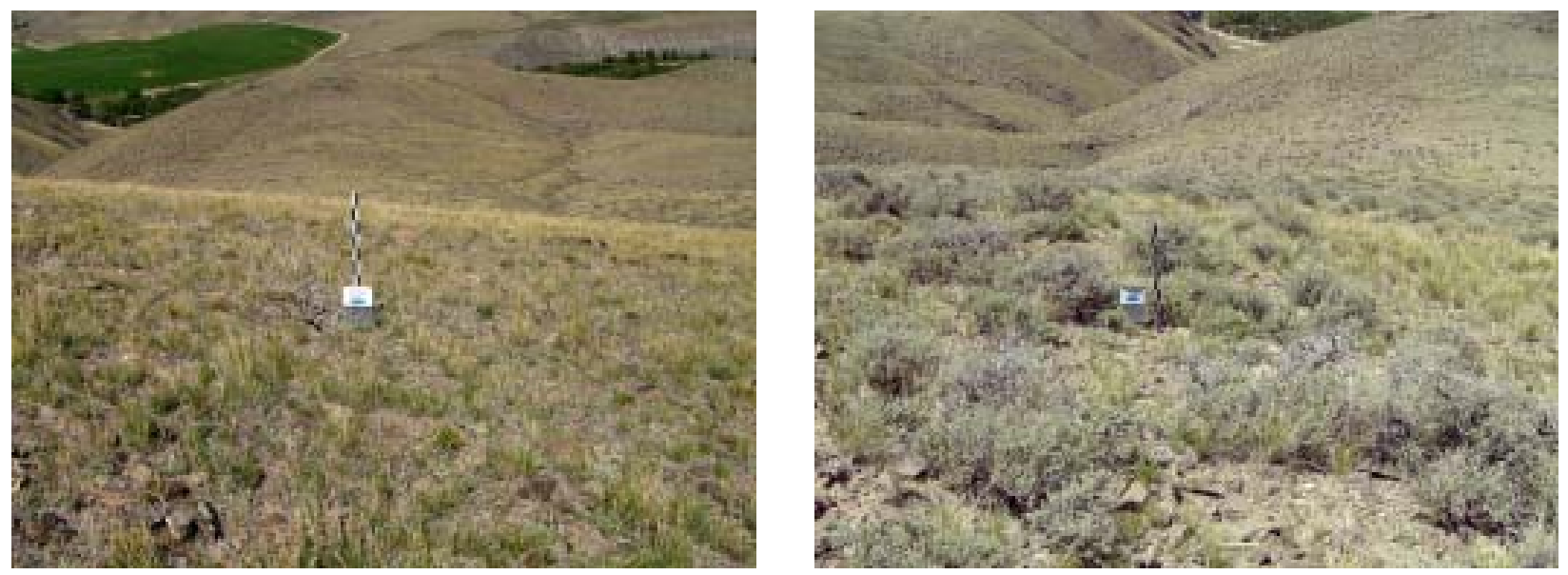

Burned (left, NHMTECSS04CL0001) and control (right, NHMTECSS04CL0002) Artemisia tridentata ssp. wyomingensis / Pseudoroegneria spicata plant association. Site is at $5910 \mathrm{ft}$. elevation with an appreciable exposure of rock/gravel. Meter stake of burn plot marks the one ssp. wyomingensis stem that was not consumed to ground level by fire; note there has been no postfire reestablishment of the shrub component in the ensuing 8 years. Control plot (in foreground) shows a patchy distribution of ssp. wyomingensis (ave. cover $=14.7 \%$ ) and $P$. spicata (ave. cover $=15.0 \%$ ) typical for these very xeric sites.
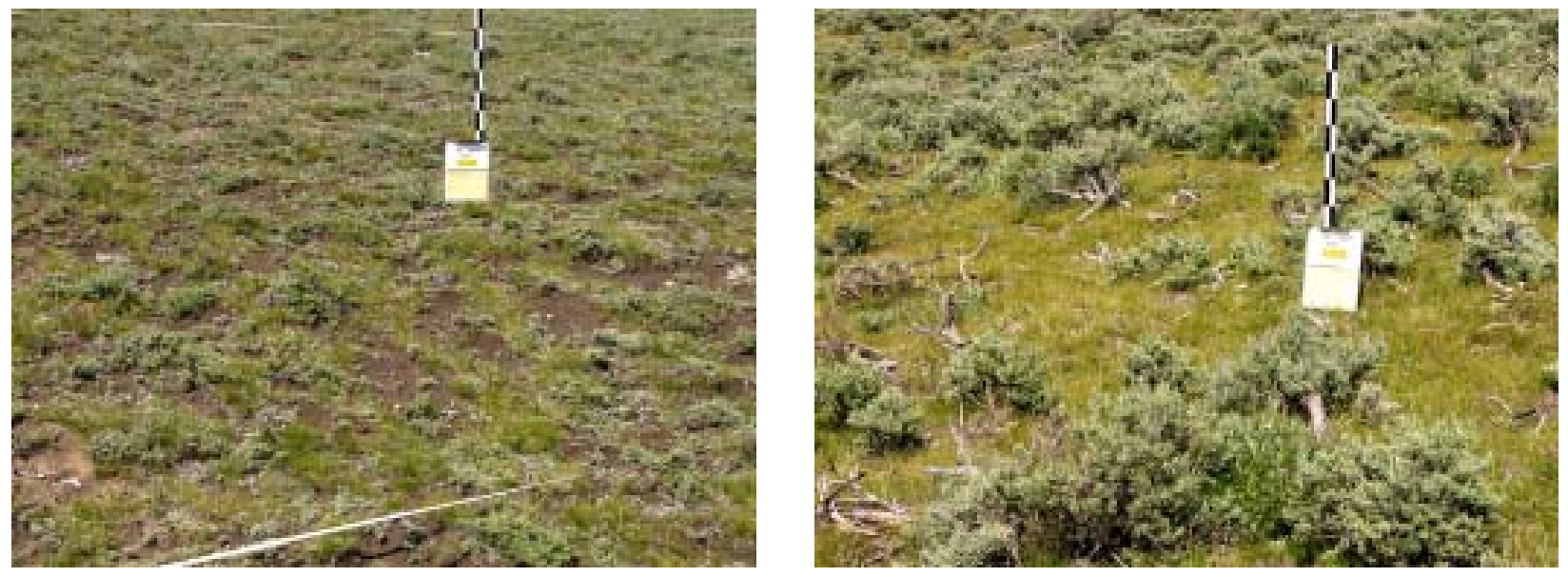

Burned (left, NHMTECSS04CL0021) and control (right, NHMTECSS04CL0022) A. tridentata ssp. wyomingensis / Festuca idahoensis plant association at 6,050 ft. in the Big Hole Valley. This site represents the mesic extreme for spp. wyomingensis; it is uncommon for it to overlap with $F$. idahoensis. In the 17 years following fire, ssp. wyomingensis has less than $1 \%$ cover whereas the control has $21.2 \%$ cover of this species. The burn plot has $17 \%$ cover of dwarf-shrub A. arbuscula, one of the more unexpected stochastic outcomes recorded. 

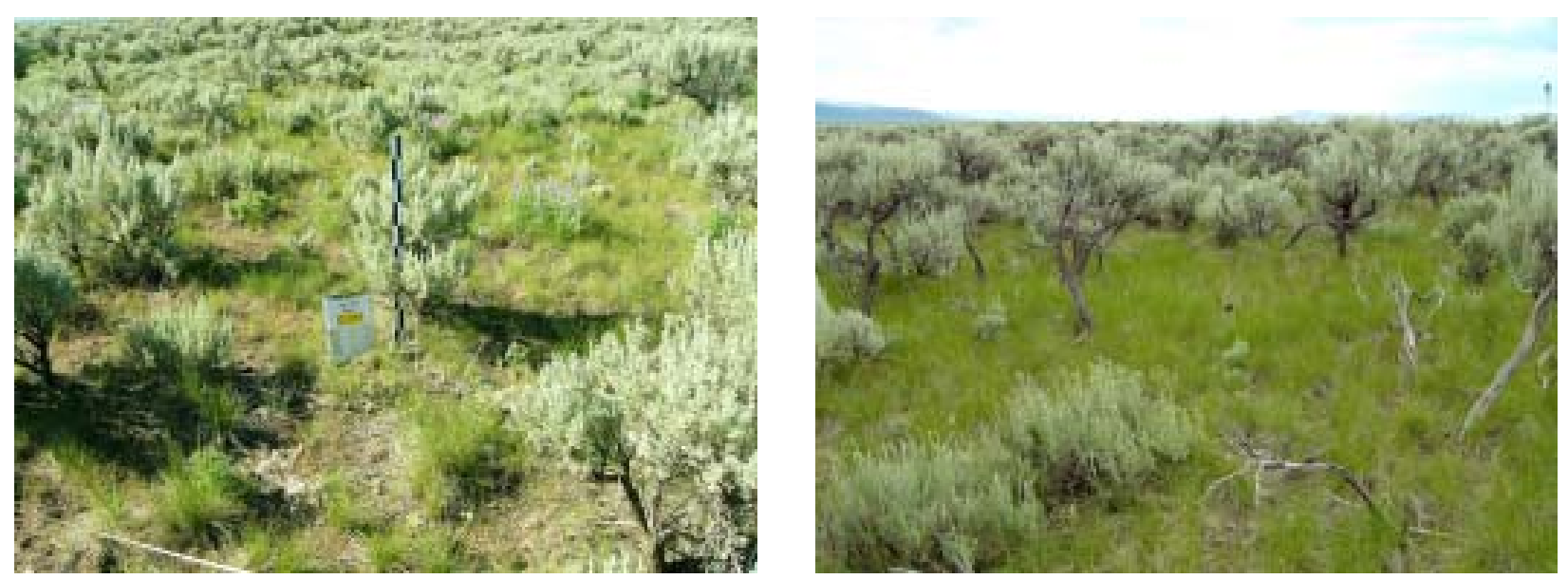

Burned (left, NHMTECSS04CL0051) and control (right, NHMTECSS04CL0052) for A. tridentata ssp. tridentata / Hesperostipa comata plant association. Site is at 6,750 ft. in the Centennial Valley sandhills (substrate $87 \%$ sands). Both A. t. ssp. tridentata and A. tripartita have flourished on the burn in the ensuing 30 years, their combined cover is $35 \%$ (30\% of which is ssp. tridentata), whereas combined shrub cover of the control plot (55 plus years old) is only $25 \%$ (of which $>99 \%$ is spp. tridentata). Natural mortality of tall ssp. tridentata stems on control plot has created a canopy gap, in which younger maturity classes of the same species have established.
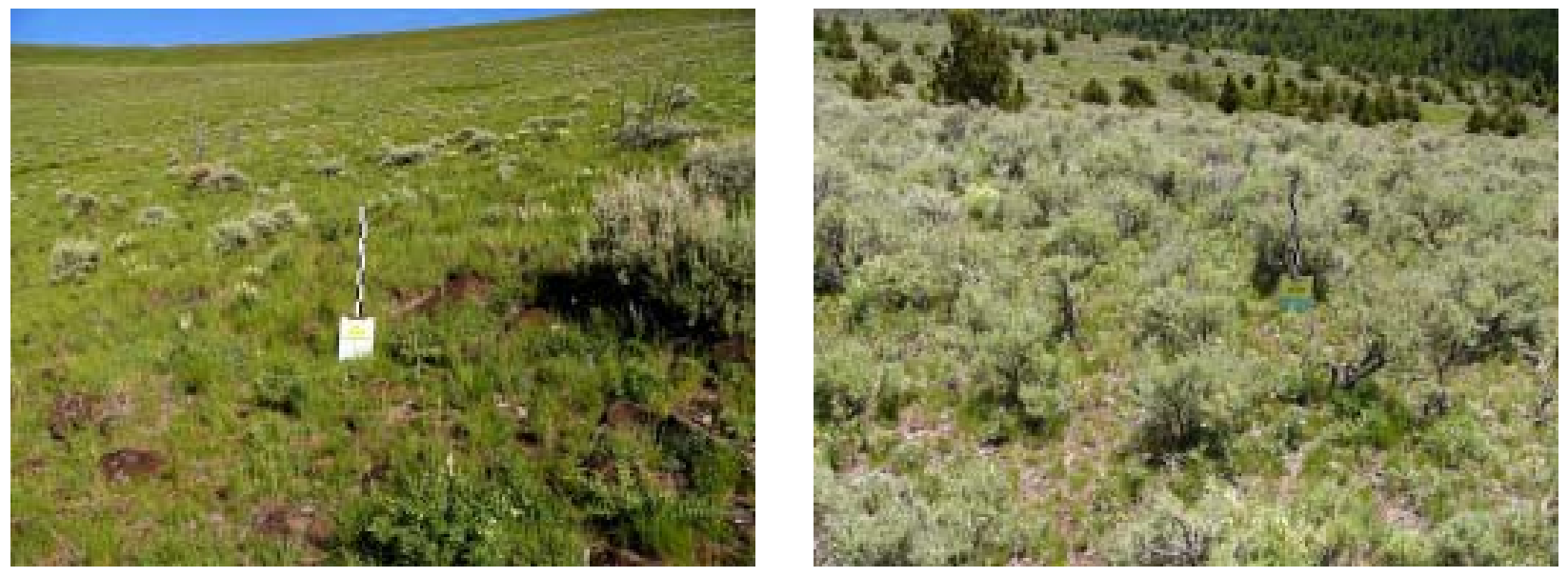

Burned (left, NHMTECSS04CL0033) and control (right, NHMTECSS04CL0034) A. tridentata ssp. vaseyana / Festuca idahoensis - Pseudoroegneria spicata plant association at the Slade Creek site at $6,500 \mathrm{ft}$ on a south-facing slope north of Virginia City. The prescribed burn conducted 21 years prior to sampling eliminated the encroaching Juniperus scopulorum. A. $t$. ssp. vaseyana has been very slow to reestablish (2.2\% burn vs. $27.1 \%$ control) on this moisture-stressed site. 

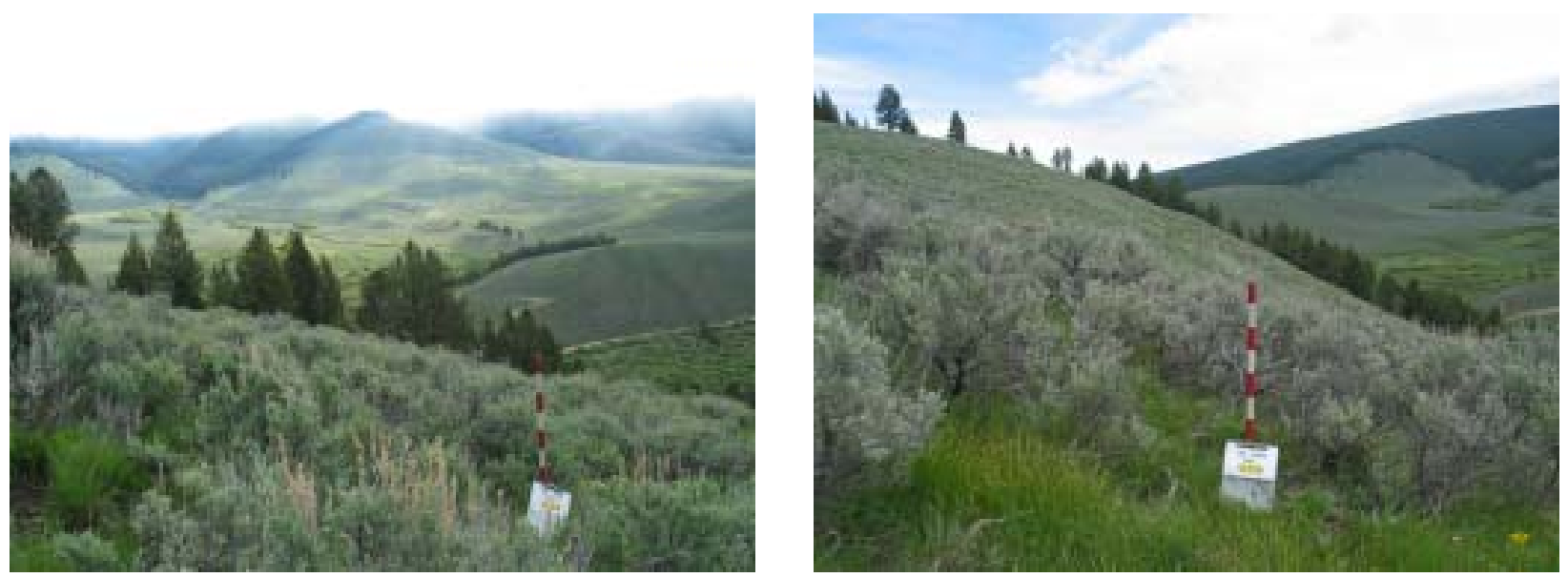

Plot pair representing burned (left, NHMTECSS04CL0018) and control (right, NHMTECSS04CL0019) for A. tridentata ssp. vaseyana / Festuca idahoensis - Geranium viscossisimum plant association. Sagebrush recovery on this mesic sites was stimulated with the cover of ssp. vaseyana on this 26 year old control burn (Bloody Dick Creek site, 7,070 ft.) notably exceeding that of the control (34\% vs. 23\%, respectively). Burn versus control cover for both the graminoid (30 vs. 33\%) and forb components (22 vs. $24 \%$ ) are probably within the error of measurement. 